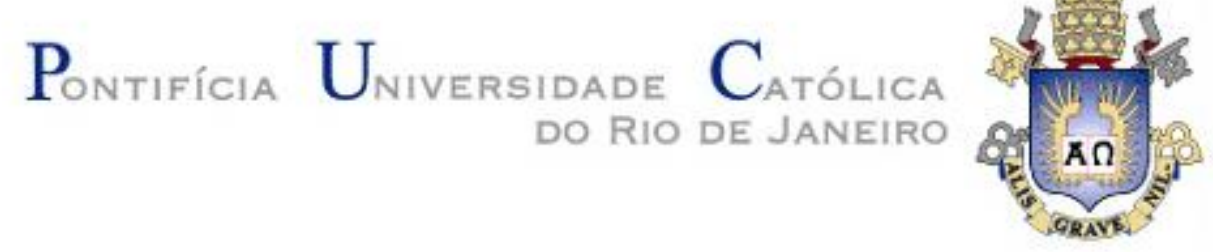

Ricardo Aguinelo Aquixinco Gomes Cá

\title{
A construção literária do estado-nação em Angola e Guiné-Bissau: um estudo comparativo entre $A$ geração da utopia e Kikia Matcho
}

Dissertação de Mestrado

Dissertação apresentada como requisito parcial para obtenção do grau de Mestre pelo Programa de Pós-graduação em Literatura, Cultura e Contemporaneidade do Departamento de Letras do Centro de Teologia e Ciências Humanas da PUCRio.

Orientador: Prof. Alexandre Montaury Baptista Coutinho 


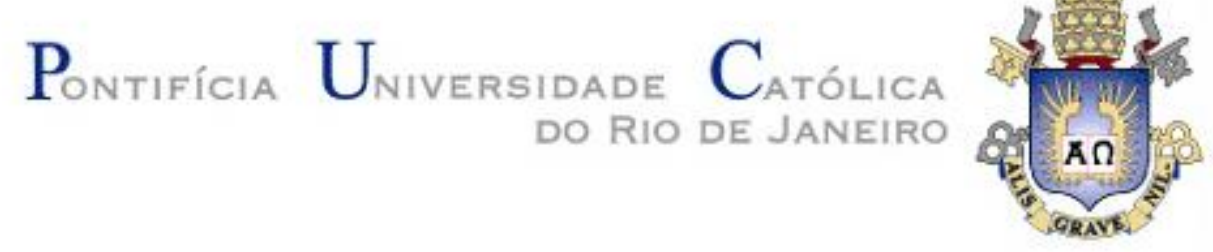

RICARDO AGUINELO AQUIXINCO GOMES CÁ

A construção literária do estado-nação em Angola e Guiné-Bissau: um estudo comparativo entre $A$ geração da utopia e Kikia Matcho

Dissertação apresentada como requisito parcial para obtenção do grau de Mestre pelo Programa de PósGraduação em Literatura, Cultura e Contemporaneidade da PUC-Rio. Aprovada pela Comissão Examinadora abaixo.

Prof. Alexandre Montaury Baptista Coutinho

Orientador

Departamento de Letras - PUC-Rio

Profa. Andrea Cristina Muraro Instituto de Linguagens e Literaturas - UNILAB

Prof. Silvio Renato Jorge Instituto de Letras - UFF

Rio de Janeiro, 16 de Abril de 2021. 
Todos os direitos reservados. É proibida a reprodução total ou parcial do trabalho sem autorização do autor, do orientador e da universidade.

\section{Ricardo Aguinelo Aquixinco Gomes Cá}

Possui licenciatura em Letras-Língua Portuguesa pela Universidade da Integração Internacional da Lusofonia AfroBrasileira, Unilab, em 2018. Fez a formação de Técnicas de Hoteleiras pela Artissal, Quinhamel-Biombo, em 2011. Foi bolsista do Programa Institucional de Bolsa de Iniciação à Docência, PIBID, em 2017-2018.

Ficha Catalográfica

Cá, Ricardo Aguinelo Aquixinco Gomes

A construção literária do estado-nação em Angola e GuinéBissau: um estudo comparativo entre $A$ geração da utopia e Kikia Matcho / Ricardo Aguinelo Aquixinco Gomes Cá ; orientador: Alexandre Montaury Baptista Coutinho. - 2021.

109 f. ; $30 \mathrm{~cm}$

Dissertação (mestrado)-Pontifícia Universidade Católica do Rio de Janeiro, Departamento de Letras, 2021.

Inclui bibliografia

1. Letras - Teses. 2. Angola. 3. Guiné-Bissau. 4. Construção da Nação. 5. Filinto de Barros. 6. Pepetela. I. Coutinho, Alexandre Montaury Baptista. II. Pontifícia Universidade Católica do Rio de Janeiro. Denartamento de Letras. III. Título. 


\section{Dedicatória}

Para minha mãe, Antónia Olitro Có, in memoriam, pelo amor, pelo carinho, pela paciência e por sua capacidade de me trazer paz na correria de cada semestre.

Ao meu pai, António Gomes Cá, pelo afeto e pela educação.

Aos meus irmãos, Victor Miguel, Domingas, Francisca, Teresa, Regina, Jorge, Adriana, Conceição. 


\section{Agradecimentos}

Foram longos anos de aprendizagem, de cansaços, de dores, alegrias e tristeza, de desesperos e motivações. Em mim carrego os silêncios de todos esses momentos, de todos os fatos que, para mim, significam um enorme aprendizado - sinal de que "caminho se faz caminhando". E esse caminhar pode ser atravessado pelas identidades e memórias que me conduziram para que eu pudesse carregar em mim a escrita utópica indispensável de Filinto de Barros, apesar de Filinto ainda ser um pouco desconhecido no Brasil. Manifesto meu agradecimento a todas as pessoas que contribuíram na grande caminhada do mestrado; em especial, ao meu orientador Prof. Dr. Alexandre Montaury Baptista Coutinho, pela dedicação em suas orientações na elaboração deste trabalho, me incentivando e colaborando no desenvolvimento de minhas ideias.

À Profa. Dra. Eneida Leal Cunha, pelas palavras valiosas durante nossas conversas sobre a relação entre Brasil e África, em especial sobre "o intelectual", num arco que passa por Zola, Benda, Gramsci, Foucault, Deleuze, Blanchot e finaliza com Edward Said e Hall: o exílio e a diáspora como figuração e potência do intelectual contemporâneo, a quem dirijo minhas mantenhas de guineendade.

Aos professores que aceitaram participar da Banca Examinadora.

Ao Prof. Dr. Frederico Coelho, pela sua presença alegre nas estupendas aulas.

Os meus sinceros agradecimentos aos colegas de turma, pelos momentos compartilhados nos corredores da PUC-Rio. Com eles pude estabelecer uma relação de amizade boa e de colaboração nas aulas.

Também dirijo meus agradecimentos ao Governo Brasileiro, pela oportunidade concedida aos estudantes guineenses no Brasil, sobretudo aos africanos.

Aos colegas e amigos guineenses de Rio de Janeiro. Não posso nomeá-los a todos, mas aqui vão alguns nomes: Adeyinka Rodrigues, Augusto Nanque, 
Eliseu lé, Hilenio Silva Monteiro, Fernando Oliveira, Jessica Araújo, pelas boas companhias ao longo deste percurso, bó seta nha mantenha de ermondadi ${ }^{1}$.

Aos meus sobrinhos, primos e tio, Alfredo Delgado, Danilo Apa Djú, Maiquel Gomes Có, Desejada Gomes Monteiro, Mohamed Gomes, Laura Cristina, Imelson Ntchala Cá, Leonardo Mimoso, Zeca Nonato Otinta, N’barsa bós risú?.

Mais uma vez, aos meus irmãos, Victor Miguel, Adriana, Domingas, Jorge, Conceição, Regina, Francisca e Teresa; ao nosso pai, António Gomes Cá, e à nossa mãe, Antónia Olitro Có, que sempre souberam nos ajudar a construir o futuro melhor nesta difícil vida do nosso cotidiano, com carinho e saudades.

À Pontifícia Universidade Católica de Rio de Janeiro pelo acolhimento.

À Secretaria do Departamento de Letras da PUC-Rio.

À CAPES e à PUC-Rio, pelos auxílios concedidos, sem os quais este trabalho não poderia ter sido realizado.

O presente trabalho foi realizado com apoio da Coordenação de Aperfeiçoamento de Pessoal de Nível Superior - Brasil (CAPES) - Código de Financiamento 001.

\footnotetext{
${ }^{1}$ Bó seta nha mantenha de ermondadi, em crioulo guineense, significa "aceitem meus sinceros comprimentos de irmandade".

${ }^{2} N$ 'barsa bós risu quer dizer um "abraço forte".
} 


\section{Resumo}

CÁ, Ricardo Aguinelo Aquixinco Gomes; COUTINHO, Alexandre Montaury Baptista (orientador). A construção literária do estado-nação em Angola e Guiné-Bissau: Um estudo comparativo entre $A$ geração da utopia e Kikia Matcho. Rio de Janeiro, 2021. 109p. Dissertação de Mestrado - Departamento de Letras, Pontifícia Universidade Católica do Rio de Janeiro.

Esta dissertação tem como eixo central uma análise comparativa entre dois romances: A geração da utopia, do angolano Pepetela (1941-), publicado em 2000, e Kikia Matcho: o desalento do combatente, do guineense Filinto de Barros (1942-), lançado em 1999. Neste trabalho, apresenta-se uma reflexão acerca de algumas linhas de força presentes nesses dois romances e analisa-se as relações de ruptura e de continuidade entre o sistema colonial e o pósindependência em Angola e em Guiné-Bissau, por meio do exame das duas obras. Ao discutirem marcas do passado literário nesses países, as escritas de Filinto de Barros e de Pepetela procuram denunciar o abandono dos excombatentes, que foram excluídos de um projeto de nação após as guerras anticoloniais (de 1961 a 1975 em Angola e de 1963 a 1973 em Guiné-Bissau). As obras selecionadas representam o modo de viver das sociedades africanas em face do crescimento da corrupção e encenam os problemas da guerrilha, a desilusão, a miséria, os conflitos sociais internos e as inúmeras decepções que surgiram depois das independências angolana e guineense. Assim, questiona-se a relação que se estabelece entre a práxis literária e as sociedades africanas, tendo como enfoque a representação das elites políticas locais.

\section{Palavras-chave}

Angola; Guiné-Bissau; Construção da Nação; Filinto de Barros; Pepetela; Literatura e Revolução. 


\section{Abstract}

CÁ, Ricardo Aguinelo Aquixinco Gomes; COUTINHO, Alexandre Montaury Baptista (Advisor). The literary construction of the nation-state in Angola and Guinea-Bissau: A comparative study between $A$ geração da utopia and Kikia Matcho. Rio de Janeiro, 2021. 109p. Master's Thesis Departamento de Letras, Pontifícia Universidade Católica do Rio de Janeiro.

This master's thesis has as its central axis a comparative analysis between two novels: A geração da utopia, by the Angolan author Pepetela (1941-), published in 2000, and Kikia Matcho: o desalento do combatente, by the Guinean writer Filinto de Barros (1942-), released in 1999. In this work, we present a reflection on some important themes present in these two novels, and we analyze the relations of rupture and continuity between the colonial and postindependence systems in Angola and Guinea-Bissau through the examination of the two novels. By discussing marks of the literary past in these countries, the writings of Filinto de Barros and Pepetela seek to denounce the abandonment of ex-combatants, who were excluded from a project of nationhood after the anticolonial wars (from 1961 to 1975 in Angola and from 1963 to 1973 in GuineaBissau). The selected works represent the way of life of African societies in the face of growing corruption and stage the problems of the guerrilla war; the disillusionment and misery; the internal social conflicts; and the countless deceptions that arose after the Angolan and Guinean independences. Thus, the relationship between literary praxis and African societies is questioned, focusing on the representation of local political elites.

\section{Keywords}

Angola; Guinea-Bissau; Building the Nation; Filinto de Barros; Pepetela; Literature and Revolution. 


\section{SUMÁRIO}

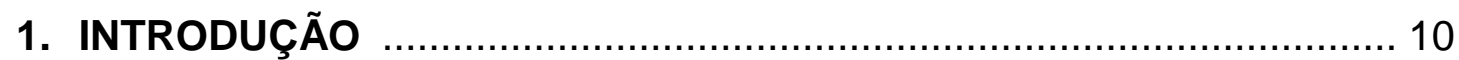

2. CONTEXTUALIZAÇÃO HISTÓRICA, CULTURAL E POLÍTICA DE GUINÉ-BISSAU

2.1 Processo de ocupação: da guerra à libertação nacional 20

2.2 A primeira manifestação literária guineense: o caminho da revolução pelas ideias 23

2.3 Memória, identidade e cultura na sociedade 26

\section{ANGOLA E GUINÉ-BISSAU: UMA POSSIBILIDADE DE COMPARAÇÃO}

3.1 Angola: uma perspectiva de reconstrução nacional

3.2 Filinto de Barros e Pepetela: o intelectual e sua missão perante as elites africanas 40

3.3 Personagens, foco narrativo, tempo e espaço em $A$ geração da utopia e em Kikia Matcho

4. A ESCRITA E A RESISTÊNCIA: UM PACTO ENTRE A FICÇÃO E A HISTÓRIA ANGOLANA E GUINEENSE

4.1 Uma nação criada e um sonho perdido: os heróis esquecidos sob os escombros 69

4.2 As contradições entre a tradição e a modernidade: uma análise das personagens Benaf, Joana e Papai 74

4.3 A simbologia das imagens do polvo e de kikia 87

5. CONCLUSÃO 98

6. REFERÊNCIAS 


\section{INTRODUÇÃO}

As literaturas africanas de língua portuguesa, de caráter nacional, nascem como uma recusa do pensamento colonial e tornam-se um espaço de protesto e de luta contra o colonialismo português. Dois caminhos tomados pelos escritores africanos contribuíram de modo significativo para isso. O primeiro tem a ver com a valorização do indivíduo africano, de sua cultura e de sua identidade. Conforme frisou Pires Laranjeira, "a formação e o desenvolvimento das literaturas africanas de língua portuguesa, desde o primeiro livro impresso, em 1849, até à actualidade, passaram pela construção do ideal nacional no discurso", (2001, p. 185). Esse ideal "atravessou, assim, diversos estágios de evolução, desde meados do século XIX até à actualidade" (ibidem). Já o segundo caminho diz respeito à recusa das práticas coloniais e à denúncia dos problemas socioculturais e políticos que existem no continente africano.

Esses caminhos foram tomados por Pepetela e por Filinto de Barros. Por causa disso, os romances $A$ geração da utopia e Kikia Matcho são representativos da literatura angolana e guineense do período pósindependência, embora retomem algumas problemáticas que surgiram ao longo da luta pela independência. Independência que - é importante relembrar — não realizou o sonho utópico, nem promoveu a melhoria das condições de vida do povo angolano e guineense, muito menos desencadeou o desenvolvimento infraestrutural e econômico de Angola e de Guiné-Bissau.

Desse modo, os escritores que tematizam a questão colonial e o pósindependência em nações africanas, em especial Filinto de Barros e Pepetela, procuram entender o complexo fenômeno político que se está desenvolvendo em cada nação independente. Eles buscam examinar as desilusões, as traições e o desprezo que surgiram no período pós-colonial e que seguem firmes até os dias de hoje. A geração da utopia e Kikia Matcho são romances que tematizam essas questões; é por isso que os examinaremos nesta dissertação.

No próximo capítulo, apresentaremos a contextualização histórica, cultural e política de Guiné-Bissau. O que se pretende é abordar como a história e a cultura da sociedade guineense nos oferecem a pista para compreendermos 
a formação da literatura do país. Como diriam Hildo Honório Couto e Filomena Embaló, uma "boa maneira de preparar o terreno para a discussão sobre a cultura, as línguas e as literaturas da Guiné-Bissau é apresentando um esboço histórico do país" (2010, p. 15).

Em nosso percurso, passaremos por alguns momentos históricos marcantes da colonização portuguesa em solo guineense, com destaque para a criação do PAIGC (Partido Africano para a Independência da Guiné e Cabo Verde) em 1956; para o massacre de Pindjiguiti em 3 de agosto de 1959; para a luta de libertação nacional a partir de 1963; e para a independência política em 1973. Também problematizaremos o sentido da memória e da identidade no processo de subalternização e de resistência das culturas locais de GuinéBissau e de Angola. Queremos demonstrar como essas duas nações buscam afirmar ou construir suas identidades de diferentes modos, uma vez que ainda estão amarradas a determinados traços da cultura do colonizador e enfrentam um constante processo de resistência.

No terceiro capítulo, veremos os processos de construção do estadonação em Angola e em Guiné-Bissau. Para isso, resolvemos analisar, pela via do estudo das obras de ficção já mencionadas, os desdobramentos negativos das elites dominantes no poder, desdobramentos que se refletem nos conflitos políticos e sociais que surgiram nos últimos anos nos dois países. Assim, debateremos os fundamentos desses Estados e suas práticas de governo; as questões da crise de liderança, liderança que se viu perdida na figura de certos governantes; os golpes do estado de 14 de novembro de 1980, entre outros; e a guerra civil em Angola e em Guiné-Bissau. Acontecimentos que causaram graves problemas internos e acarretaram 0 atraso no processo do desenvolvimento socioeconômico, cultural e político das duas nações. A essas distorções provocadas pelo colonialismo português "somaram-se outras contingências implicadas na transferência do poder político em meio a conflitos armados, corrupção e outros abusos próprios de sociedades em convulsão" (SARAIVA, 2016, p. 8).

Ainda nesse capítulo, refletiremos sobre o papel do intelectual e sobre a missão do intelectual perante as elites africanas. O espírito crítico dos escritores africanos começou a ganhar força por meio de um trabalho árduo que visa a eliminar as mazelas que surgiram depois da luta anticolonial. A respeito dessa questão, podemos estender a assertiva de Maria Fernanda Afonso - que diz que "o comprometimento do escritor com a nação é um traço fundador da literatura moçambicana" (2004, p. 392) - para os escritores angolanos e 
guineenses. Em relação a Pepetela e a Filinto de Barros, faremos uma análise comparativa de seus romances - A geração da utopia e Kikia Matcho -, para entender como os elementos estéticos (personagens, foco narrativo, tempo e espaço) dessas obras facilitam a compreensão das questões que nelas são problematizadas.

No quarto capítulo, vamos refletir sobre a relação entre literatura e sociedade, de modo a captar como se projeta a escrita literária na construção da história recente de Angola e da Guiné Bissau, história que vem da luta anticolonial, passa pelo pós-independência e chega até os dias atuais. Abordaremos as contradições entre tradição e modernidade, com base no exame detido de algumas personagens de Kikia Matcho. Além disso, examinaremos as representações simbólicas do polvo e de kikia, tomando como ponto de partida a relação que a obra de Pepetela e a de Filinto de Barros estabelecem com o cenário cultural que surge na década de 1970 e vem até os dias atuais e das relações que se estabelecem, por meio das personagens, entre o tempo passado e o presente.

Por fim, no último capítulo, serão apresentadas as considerações finais de nosso estudo. Em suma, Pepetela e Filinto de Barros demonstram-se perfeitamente capazes de refletir sobre tensões políticas e sociais, sobre as contradições e as ambivalências do processo de formação das nações angolana e guineense. Além disso, nos romances analisados neste trabalho, os dois escritores retratam o pós-independência nas duas nações de forma magistral, destacando, entre outras coisas, os meandros e as mazelas de duas sociedades recém-independentes imersas em disputas políticas e em jogos de poder, que produzem seus efeitos até os dias de hoje.

Acreditamos que as obras de Pepetela e de Filinto de Barros examinadas nesta dissertação podem servir de auxílio na discussão acerca da construção das nações de Angola e de Guiné-Bissau e na problematização da flutuação dos papéis de intelectuais africanos. Em relação ao papel social de nosso trabalho, cremos que nossa análise possa ser proveitosa para os estudos de literaturas africanas de língua de portuguesa, pois nossas reflexões dialogam com as mudanças ocorridas nas sociedades angolana e guineense. 


\section{CONTEXTUALIZAÇÃO HISTÓRICA, CULTURAL E POLÍTICA DE GUINÉ-BISSAU}

A Guiné-Bissau é uma república situada na costa ocidental da África e banhada pelo oceano atlântico. Faz fronteira ao norte com a República do Senegal e ao sul com a República da Guiné Conakry e possui população de 1.548.159 habitantes, de acordo com os dados do último recenseamento feitos pelo INEC (Instituto Nacional de Estatística e Censo) em 2009. Esses habitantes são divididos, aproximadamente, em trinta grupos étnicos. Entre eles, destacamse os seguintes: Balantas, Fulas, Mandingas, Manjacos, Pepéis, Mancanhas, Biafadas, Bijagós, Felupes, Balanta-Mané, Mansoanca, Baiote, Nalus, além de outros grupos menores. Dentro desses grupos étnicos, existem ainda subdivisões.

Também é importante destacar que a Guiné-Bissau compreende ainda os arquipélagos dos Bijagós, formado por mais de oitenta ilhas. A superfície total do país é de $36.125 \mathrm{~km}^{2}$, que se dividem em oito regiões e em trinta e sete setores, além do setor autônomo de Bissau, que corresponde à cidade de Bissau, a atual capital do país.

O português é língua oficial de Guiné-Bissau; mas o crioulo guineense é a língua mais falada pela população. Além disso, é a língua da unidade nacional, pois é usado na comunicação entre os diferentes grupos étnicos, muito embora cada um desses grupos tenha a sua própria língua. De modo geral, mais de trinta línguas étnicas são faladas no país.

Durante a segunda metade do século XX, na Guiné-Bissau, Amílcar Cabral e outros fundaram o Partido Africano para a Independência da Guiné e Cabo Verde (PAIGC). Isso aconteceu, mais especificamente, em 1956. Durante três anos, a resistência do PAIGC foi pacífica; mas após o Massacre do Pindjiguiti, de 3 de agosto de 1959, o partido se revoltou contra o regime ditatorial português.

No dia do massacre, os trabalhadores do Porto de Bissau (estivadores e marinheiros) encontravam-se em greve, exigindo melhorias salariais, até que as 
forças portuguesas da $\mathrm{PIDE}^{3}$ interromperam uma manifestação e deixaram mais de cinquenta pessoas mortas e mais um sem-número de outras pessoas feridas. Por conta disso, o dia 3 de agosto é considerado um dos marcos do início da luta pela libertação da Guiné-Bissau e atualmente é um dos feriados mais importante do país, conforme destaca Benzinho e Rosa (2015).

A partir de 1963, teve início a luta entre as tropas portuguesas e os guerrilheiros caboverdianos e guineenses do PAIGC. A guerra durou onze anos, e a vitória do PAIGC foi proclamada no dia 24 de setembro de 1973, nas matas de Madina de Boé, situadas no leste da Guiné-Bissau. Após a Revolução dos Cravos e a queda do regime de Salazar, Portugal reconheceu oficialmente a independência da República da Guiné-Bissau no dia 10 de setembro de 1974.

Importa salientar que o processo da luta armada de independência contra os portugueses que ocorreu na Guiné-Bissau envolveu os povos da GuinéBissau e de Cabo Verde. O principal projeto do PAIGC, liderado por Amilcar Cabral, era unir as populações guineenses e cabo-verdianas, para lutar contra a colonização portuguesa, com o propósito de construir uma nação livre e independente. Para Amílcar Cabral, a luta era a única forma de garantir a libertação nacional.

Amílcar Cabral enfatiza que a "unidade dinâmica" significava colocar de lado as diferenças que pudessem existir entre os grupos étnicos guineenses envolvidos na luta pela libertação, pois essa dinâmica poderia contribuir para eliminar o "inimigo comum", o colonialismo português, conforme podemos acompanhar no seu discurso citado pelo sociólogo guineense Carlos Lopes: "há dez anos, nós éramos Fulas, Manjacos, Mandingas, Balantas, Papeis e outros [...] agora somos uma nação de guineenses" (CABRAL apud LOPES, 1987, p. $60)$.

Apesar dos esforços de Amílcar Cabral para justificar a luta pela libertação, o processo de construção da unidade nacional entre Guiné-Bissau e Cabo-verde não parece ter sido consensual. Peter Karibe Mendy (1993, p. 28) afirma que o projeto de unificação não teve apoio da massa popular, já que a elite caboverdiana não confiava numa relação de irmandade com o povo guineense. Além disso, havia rixas internas no PAIGC. O partido estava fragmentado entre as elites cabo-verdianas e guineenses, e estas sentiam-se injustiçadas perante aquelas, que controlavam o partido. Os guineenses questionavam o fato de que havia exploração de recursos na Guiné-Bissau em benefício de Cabo-Verde.

\footnotetext{
${ }^{3}$ Polícia Internacional e de Defesa do Estado entre 1945 e 1969.
} 
Quando saiu da luta armada em 1974, para implementar o início da primeira República, o PAIGC assumiu pela primeira vez a liderança nacional e deparou-se com o desafio de lidar com a complexidade dos processos democráticos, principalmente com as contradições que adivinham da distribuição dos cargos públicos e com a garantia do bem-estar do povo. A situação era difícil porque era primeira vez em que o partido realmente tinha contato com as exigências de governar. Para piorar, não havia militantes suficientes com as qualidades técnico-administrativas necessárias para garantir 0 bom funcionamento da máquina pública. Como a formação da elite guineense é anterior à composição do PAIGC e teve o seu começo durante o processo colonial, a estrutura social era exclusiva e hierarquizava indivíduos "civilizados" (os assimilados) ${ }^{4}$ e indígenas. Essa estratégia teve como objetivo forjar uma elite de assimilados que tinha como missão servir ao sistema de dominação colonial e ao mesmo tempo auxiliar na defesa dos interesses colonizadores.

Com a realização do Congresso de Cassacá, que ocorreu em 1964, nas chamadas zonas libertadas da Guiné-Bissau, o PAIGC criou um projeto educativo que visava a formar um homem novo e consciente da sua realidade social e que, ao mesmo tempo, pretendia libertar o país de qualquer tipo de exploração e da opressão colonial.

De acordo com Frantz Fanon,

A descolonização nunca passa despercebida, pois diz respeito ao ser, ela modifica fundamentalmente o ser, transforma espectadores esmagados pela inessencialidade em atores privilegiados, tomados de maneira quase grandiosa pelo rumo da história. Ela introduz no ser um ritmo próprio, trazido pelos novos homens, uma nova linguagem, uma nova humanidade. A descolonização é verdadeiramente a criação de homens novos (2005, pp. 52-53).

Para Amílcar Cabral (1979), o termo "a luta" não se limita à luta contra o colonialismo português; mas refere-se ao combate contra qualquer tipo de exploração, assim como àquele contra a "natureza", o "medo", os "aspectos negativos da nossa cultura", entre outras coisas. A luta, nesse sentido, aponta para a "resistência", que pode ser política, armada, econômica e cultural.

Com a implementação do Estado Moderno baseado no modelo que vinha da Europa, devido à política de assimilação praticada pelo colonialismo europeu

\footnotetext{
4 "A separação da classe nativa guineense em duas categorias, assimilados e indígenas, são, a nosso ver, pressupostos de dominação que foram criados para de alguma forma favorecer interesses coloniais, mas que acabou sendo um entrave para os propósitos da colonização. Isto porque foram as elites nativas das cinco ex-colônias que forjaram através dos movimentos por eles criados e dirigidos a retirada de Portugal da África (SEMEDO, 2011, p. 100)."
} 
na África, em especial na Guiné-Bissau, permitiu-se a ruptura da violência e da política colonial, que impunha a implementação administrativa do Estado colonial português.

Jorge Otinta (2011, p. 136) afirma que "entre rupturas e continuidades", ou seja, entre os fatos da independência e da pós-independência, a formação da elite intelectual guineense no campo do poder político remonta ao PAIGC. Em junho de 1991, ocorreu a reunião do Comitê Central do PAIGC, que reuniu cento e vinte um militantes, os quais, em sua maioria, eram jovens intelectuais do partido no poder. Esses militantes manifestavam fidelidade ao PAIGC e, consequentemente, reafirmavam serem os salvadores do partido. Em outras palavras, mostravam disposição para a luta de salvação do PAIGC.

Esse grupo de militantes propunha restabelecer o diálogo construtivo com as formações políticas iniciantes e também queria restaurar a confiança dos seus companheiros e de simpatizantes do partido. Eles buscavam as condições que permitissem o desenvolvimento econômico "autônomo de modo a evitar a degradação da situação econômica e financeira por que [o país] passava a partir da liberação econômica dos anos 80" (idem, p. 134).

Com a transição para a independência e a democracia, fenômeno recente, dos anos 1990 aos dias atuais, a construção do processo da "unidade nacional" baseada na ideologia da identidade política não mais constituía a democracia revolucionária, e os compromissos assumidos pela novas elites políticas e intelectuais guineenses consistiram em disciplinar e em adotar regras válidas e normas constitucionais para os atores políticos e sociais na participação da vida pública.

De uma perspectiva política, a Guiné-Bissau viveu sucessivas instabilidades desde sua independência até os dias de hoje. Em 1991, por exemplo, foi aprovado o multipartidarismo; três anos depois, já em 1994, o PAIGC ganhou as primeiras eleições multipartidárias; mas, logo em seguida, após a guerra civil de 1998-1999, conhecido como a guerra de sete de junho, o presidente João Bernardo Nino Vieira foi destituído.

Assim, o Estado Bissau-guineense adotou oficialmente o sistema semipresidencialista, que foi oficializado a partir das primeiras eleições presidenciais e legislativas ocorridas em 1994, quando a população guineense elegeu João Bernardo Vieira como presidente. É importante lembrar que, após a independência, o país viveu vários anos sem eleições, sob o comando de um partido único, o PAIGC, o partido libertador. 
Em termos de democracia, a realização das eleições gerais de 1994 foi, em tese, um ato importante e marcante para a sociedade guineense; na prática, porém, a realização das eleições não significou muita coisa, nem chegou perto de ser a solução dos problemas sociais e políticos existentes. As eleições trouxeram apenas a desilusão para o povo guineense, que se viu obrigado a recuperar suas esperanças.

As primeiras eleições multipartidárias ressaltaram as tensões existentes entre os políticos e geraram várias consequências trágicas para as populações guineenses - sucessivos golpes de Estado; quedas de governos; perseguições e assassinatos políticos; lutas pelo acesso ao poder com base nas pretensões pessoais dos políticos; fome; miséria.

Segundo Moema Parente Augel, as "esperanças que foram depositadas nas eleições" (1996, p. 75), eleições que quase sempre foram vencidas pelo PAIGC, naufragaram, uma vez que os governos não resolveram seus impasses políticos, tampouco os problemas estruturais do país.

As lideranças políticas dos principais partidos da Guiné-Bissau não conseguiram até então mostrar uma boa parceria ou uma agenda política que envolvesse todos os atores políticos, para obter uma boa governação, em nome da paz e da estabilidade social e política no país. Segundo Filinto de Barros, "sem o líder, os herdeiros não foram capazes de prosseguir com a vertente crítica e inovadora do modelo cabralista. Seguiram mecanicamente os escritos do líder. É aqui que reside o dilema pós-independência" (BARROS apud SUCUMA, 2018, p. 75).

Considerando que Amílcar Cabral, a propósito da unidade de Guiné-Bissau e de Cabo-Verde, propôs um pacto corajoso para criar uma nação independente, livre e transparente, que visava a eliminar a realidade herdada do colonialismo, é necessário reconhecer a incapacidade dos herdeiros políticos de prosseguir com a dinâmica criativa que levaria cada um dos dois Estados a ser gerido pelos compatriotas e a defender a unidade, a luta e o progresso. A ideia de unidade nacional, de uma unidade pautada no diálogo, na criação de oportunidades para a nova geração e no esforço de transformar a Guiné num país próspero - isso foi deixado de lado. O problema da instabilidade política na Guiné-Bissau revela uma completa falta de comprometimento com a nação.

Na realidade, o novo poder que se instalou em Guiné-Bissau desde 1974 nunca escondeu o seu caráter repressor, autoritário e intimidatório, e ao longo dessas décadas houve constantes crises políticas e golpes militares, que criaram 
obstáculos praticamente intransponíveis para desencadear o desenvolvimento do país.

A década de 1990 chegou a representar um período de alguns avanços em termos cívico-democráticos, um período em que o país ascendeu social e economicamente, em que surgiram oportunidades aos jovens de uma nova geração de políticos; só que boa parte desses políticos se revelou descomprometida com o desenvolvimento do país; boa parte desses políticos desviou-se da ideologia revolucionária da luta armada (unidade luta progresso). É exatamente a grande maioria dessa geração de políticos que perturba a sociedade Bissau-guineense, com apoio dos militares, provocando sucessivas instabilidades políticas e institucionais, que assolam as instituições guineenses.

A maioria das grandes elites governantes guineenses teve participação ativa constante na desestabilização do país, numa aliança com os militares envolvidos no processo. João José Silva Monteiro ${ }^{5}$ afirma, em entrevista concedida a uma agência de notícias portuguesa, que a Guiné-Bissau "tem vindo a sofrer sucessivas instabilidades na cúpula do poder político e que não consegue estabilizar-se" (MONTEIRO apud SUCUMA, 2018, p. 63). Dessa forma, nenhum país consegue andar para frente. Nenhum país consegue prosperar.

A análise de Monteiro demonstra como a instabilidade política em GuinéBissau vem sendo motivada pela busca irrestrita de poder, assim como pelo controle do Estado fora das regras do jogo democrático. A sucessiva troca de governos coaduna-se com o interesse dos políticos em acumular fortuna para 0 bem de suas famílias, e não para o bem da população. Outra questão importante é que o próprio país se prende à história da luta de libertação nacional - luta que foi bastante violenta. É por causa disso que a violência ainda está presente na vida política. Aliás, a vida política é, ela mesma, caracterizada pela violência. Esse fato também é observado em Angola. No caso guineense, isso se dá porque o PAIGC sempre liderou o país nos espaços político e militar, em oposição ao colonialismo, e chegou à independência com certa estabilidade de governo. Nesse processo de luta contra o colonialismo, não se pode esquecer

\footnotetext{
${ }^{5}$ João José da Silva Monteiro, também conhecido como Huco Monteiro, ocupou várias pastas ministeriais, como Educação, Negócios Estrangeiros, Conselheiro do Presidente da República nas áreas da Educação e Saúde. Foi Fundador e presidente do Conselho de Administração da Universidade privada Colinas de Boé. Também foi Presidente do Conselho de Administração do Ecobank na Guiné-Bissau, Secretário Executivo de Secretariado Nacional de Luta contra a Sida (SNLS) e Comissário para Recursos Humanos da Comunidade Económica dos Estados da África Ocidental (CEDEAO).
} 
da violência política praticada contra aqueles que tinham outras ideias sobre os rumos tomados pela libertação do país, como a FLING ${ }^{6}$ e muitos outros movimentos da burguesia guineense.

Como se pode ver, não é por acaso que, após a independência política, o Estado guineense experimenta até hoje instabilidades políticas constantes. Instabilidades que constituem um dos principais obstáculos à construção do estado-nação, à implementação de políticas educacionais e ao aperfeiçoamento da democracia.

Enquanto isso, a população, cada vez mais empobrecida, vê-se obrigada a lutar, dia após dia, pela própria sobrevivência. A ampla maioria do povo sequer possui acesso a condições minimamente razoáveis de saúde; faltam os meios necessários para o exercício de uma boa medicina nos hospitais públicos e privados. Para piorar, a população ainda enfrenta problemas gravíssimos na educação. Além da baixa qualidade do ensino, é comum acontecerem greves de professores e de funcionários, que muitas vezes ficam meses sem receber salários, não encontram uma infraestrutura decente para exercerem seus ofícios e anseiam por uma reestruturação efetiva de suas carreiras.

Em Kikia Matcho, os bairros bissauenses são muito bem representados pelo bairro Tchon de Pepel. "Destituídos de qualquer sistema de saneamento básico, praticamente sem água potável e canalizada, sem luz e com casas de barro empilhadas uma em cima das outras" (BARROS, 1999, p. 10), esses bairros faziam a cidade adormecer numa profunda escuridão. Escuridão que a "falta da lua tornava ainda mais triste" num continente que teimava em manter-se no escuro das independências, no escuro do analfabetismo. Escuridão como "a cor da pele da maioria dos seus habitantes" (BARROS, 1999, pp. 14 -15).

Acreditamos que os processo históricos e políticos que acabamos de apresentar nos ajudam a refletir e a compreender a construção do Estado Bissau-Guineense após sua independência política. Em nossa reflexão, levamos em consideração a complexidade social, histórica e cultural do país. Devido a essa complexidade, os primeiros anos de independência da Guiné-Bissau, por um lado, foram utópicos em termos de desenvolvimento socioeconômico e infraestrutural; por outro, foram marcados por tensões políticas balanceadas entre os políticos do PAIGC. Muitos desses políticos foram presos, torturados e perseguidos. Fins semelhantes tiveram os cidadãos que criticavam o regime do

\footnotetext{
${ }^{6}$ Frente de Libertação Nacional da Guiné.
} 
partido único, partido que, na época, se resumia ao PAIGC. Os conflitos políticos produzidos entre os governantes guineenses ainda causaram a queda de inúmeros governos e geraram imensa instabilidade política no país. Vale lembrar que a liberdade de expressão também foi ameaçada constantemente antes da época do multipartidarismo democrático. Na realidade, ela segue ameaçada até hoje.

Esperamos ter apresentado características relevantes do complexo processo das grandes transformações sociais ocorridas na sociedade guineense no período do pós-independência. Essas transformações encontramse impressas no cotidiano do país e na relação entre suas classes sociais. Se durante muito tempo essas classes foram diferenciadas, hoje, na atual situação social do país, situação de profunda miséria, elas irmanam-se e acolhem a cínica relação de djitu ka ten ${ }^{7}$.

\section{1}

\section{Processos da ocupação: da guerra colonial à libertação nacional}

Segundo Moema Augel (2007, pp. 51-52), os navegadores portugueses chegaram à costa da Guiné em 1445, ano em que Nuno Tristão vinha da costa senegalesa com o propósito de efetuar trocas comerciais com os chefes locais. Essas trocas eram combinadas entre esses chefes e os colonizadores portugueses.

Além disso, de acordo com o livro História da Guiné e ilhas de CaboVerde, publicado em 1974 pela editora Afrontamento, durante as trocas, os chefes guineenses recebiam armas em troca de pessoas escravizadas, e essas armas se tornariam mais tarde importantes instrumentos para as lutas anticoloniais.

Outros historiadores registram a chegada dos portugueses à Guiné-Bissau no ano de 1446. Séculos depois, Álvaro Fernandes chegaria à praia de Varela ${ }^{8}$ no fim da Primeira Guerra Mundial, em conformidade com "o falso pretexto do zelo pelo bem-estar e desenvolvimento dos povos africanos no quadro da dita missão de civilização" (FURTADO, 2005, p. 248). Amílcar Cabral (1978, p. 98)

\footnotetext{
${ }_{8}^{7}$ Djitu ka ten quer dizer não tem problema.

${ }^{8}$ Varela encontra-se a $175 \mathrm{~km}$ da capital, Bissau. Chegando a São Domingos, e em vez de seguir a estrada alcatroada para o Senegal, encontra-se numa picada de $53 \mathrm{~km}$ que nos leva à praia continental mais bonita da Guiné-Bissau (BENZINHO \& ROSA, 2015, p. 68).
} 
afirma que a "Guiné Portuguesa", atual Guiné-Bissau, era governada por um único administrador, indicado pelo governo colonial português.

A presença portuguesa no território guineense inicia-se na região de Cacheu, que, na altura, era administrativamente ligada a Cabo-Verde. A cidade de Cacheu ficou conhecida pelo famoso "porto de águas fundas, ideais para o transporte marítimo de ouro, marfim, especiarias e de escravos", para além do comércio que os portugueses faziam ali. Joana Benzinho e Marta apontam que a cidade também era "conhecida como casa dos portugueses 'lançados' (aventureiros) e dos 'degredados' (condenados ao exilio)" (2015, p. 11).

É válido lembrar que, em 1879, foi procedida a separação administrativa de Cabo-Verde, na qual se constituiu mais uma colônia de Portugal, que teve como primeira capital Bolama, atualmente considerada uma das regiões da Guiné-Bissau.

Em 1951, em face da pressão internacional, o estatuto de colônia da Guiné Portuguesa foi substituído pelo estatuto de Província Ultramarina, mas a resistência e a luta pela autodeterminação guineenses persistiram, tendo resultado no marco histórico da fundação do PAIGC.

Para Alexandre Brito Ribeiro Furtado (2005), com a emergência da nova forma de colonização iniciada no século XIX na Guiné Portuguesa, que foi conhecida como "sistema colonial", surgiu a "Educação Colonial", que começou a funcionar de forma perceptível, embora fosse limitada a poucas pessoas, que apenas recebiam instruções básicas, tais como ler, escrever e aprender falar a língua portuguesa.

Assim, a educação colonial portuguesa pode ser dividida em duas fases: a primeira, que se iniciou em 1471 e que vai até a primeira metade do século XIX, e a segunda, que durou de 1971 até 1974, até o fim da colonização portuguesa, ano em que Portugal reconheceu a Guiné-Bissau como nação independente.

A primeira fase da educação colonial funcionava de uma forma não institucionalizada e se limitava às pessoas que colaboravam com o regime colonial. Essas pessoas eram conhecidas como cabo-verdianos e geralmente ocupavam a função de servidores coloniais de baixo escalão. Desse modo, a educação colonial era restrita às populações guineenses, pois visava às pessoas que colaboravam com a modificação de suas práticas, a fim de imitar as práticas dos colonizadores e a civilização europeia.

$\mathrm{Na}$ verdade, era uma educação precária e limitada, principalmente para as pessoas influentes, que mostravam interesse em cooperar com o regime colonial. De acordo com Hilda Almeida (1981), os portugueses não tinham 
interesse em ministrar qualquer tipo de ensino às populações colonizadas, porque suas preocupações eram mais voltadas para as "atividades econômicas que desenvolviam nas colônias" (pp. 30-31).

Já a segunda fase da educação colonial começou na segunda metade do século XIX, após a Conferência de Berlim, que ocorreu entre 1884 e 1885 e deu origem à partilha da África e às normas do direito internacional colonial. Brito Ribeiro (2005, p. 248) descreve que essas normas foram ampliadas durante a realização da Conferência de Bruxelas, em 1890, onde foram debatidas as formas de combate ao tráfico dos africanos escravizados e a proteção das instituições criadas para instrução dos nativos indígenas das colônias africanas. A pesquisadora salienta ainda que, apesar da decisão tomada na Conferência de Bruxelas, é importante lembrar que a decisão voltou a ser discutida nas conferências internacionais.

Após a Conferência de Berlim, em que Portugal apresentou o falhado "Mapa Cor-de-Rosa", apressou-se a efetivação do povoamento da Guiné-Bissau, com objetivo de fomentar a agricultura, sem qualquer resistência da população ou sem combates sanguinários. Assim, o governo colonial português passou a preocupar-se mais com a ocupação territorial efetiva de suas colônias, a fim de realizar suas atividades econômicas, que visavam ao desenvolvimento da metrópole.

Benzinho e Rosa afirmam que, em 1936, verificou-se a última grande revolta, conhecida como a revolta dos Bijagós de Canhabaque ${ }^{9}$, quando a população guineense foi então "obrigada ao trabalho forçado, às infraestruturas pouco foram desenvolvidas e foi dada a preferência para a nomeação de caboverdianos como funcionários" (2015, p. 12).

Como efeito dessa nova ocupação, Portugal levou consigo violentas guerras de conquistas em suas colônias, onde encontrou resistência dos povos colonizados, que não aceitaram a usurpação dos seus respectivos territórios.

No caso da Guiné-Bissau, os colonizadores portugueses deram o nome de "Campanha de Pacificação" a esse processo que durou cinquenta anos, porque o arquipélago dos Bijagós, na província sul do país, somente foi conquistado em 1936, em concordância com Mendy (1994). Mendy acrescenta que, apesar dessa ocupação territorial, a Guiné portuguesa (atual Guiné-Bissau), nunca foi

\footnotetext{
${ }^{9}$ Segundo Dabana Namone, "em 1900, a tribo Bijagó, residente nas ilhas do mesmo nome, foi a primeira a entrar em conflito armado com os portugueses e viria também a ser a última conquistada, em 1936. Esse grupo, principalmente os habitantes da ilha de Canhabaque, resistiram durante todo esse período à dominação colonial e ao pagamento do imposto de palhota" (2014, p. 49).
} 
"colônia de habitação", e sim de "exploração"; por isso a presença dos portugueses na Guiné-Bissau foi sempre desinteressante. Até a independência, em 1973, a população portuguesa ultrapassava 5.000 habitantes (ALMEIDA, 1981, p. 36).

Apesar dos pequenos números de portugueses em solo guineense, Cabral argumenta que "a ocupação efetiva dos portugueses permitiu a exploração e a violenta marginalização das populações guineenses, porque as obrigavam a cultivar certos gêneros alimentícios e a realizar trabalhos forçados" (1978, p. 18).

É importante ressaltar a capacidade do líder guineense Amílcar Cabral em análise política. Um exemplo disso é quando ele afirma que a luta do PAIGC era contra o colonialismo português, e não contra o povo de Portugal. Diz ele:

\footnotetext{
"Nós nunca confundimos 'colonialismo português' com o 'povo de Portugal' e temos feito tudo, na medida das nossas possibilidades, para preservar, apesar dos crimes cometidos pelos colonialistas portugueses, as possibilidades de uma cooperação, de amizade, de solidariedade e de colaboração eficaz com o povo de Portugal, numa base de independência, de igualdade de direitos e de reciprocidade de vantagens, seja para o progresso da nossa terra, seja para o progresso do povo português (CABRAL, 1974, p. 18).
}

Em vista dos argumentos apresentados, Amílcar Cabral (1978, p. 57) reconhece que a vida coletiva e privada das populações guineenses passa a ser totalmente controlada pelos colonizadores por meio da violência. $E$ tal controle baseia-se no fato de que Portugal tinha um governo de domínio total desde 1834 e, quando o capitalismo europeu se encontrava numa fase de livre concorrência, o Estado Português usou o princípio da liberdade e da igualdade para favorecer a penetração dos capitais europeus em todas as áreas, tanto nas metrópoles quanto nas colônias, conforme expressa Almeida (1981, p. 31).

\section{2}

\section{A primeira manifestação literária guineense: o caminho da revolução pelas ideias}

O processo de surgimento das Literaturas Africanas de língua portuguesa passou por duas instâncias históricas importantes: a escola e a prisão. Do ponto vista histórico, Patrick Chabal, ao referir-se ao relacionamento do escritor africano com o enorme campo de sua influência que constitui a oralidade, propõe quatro fases abrangentes dessa literatura. 
Segundo a perspectiva de Chabal (1994), a primeira fase é a da assimilação, na qual os escritores africanos, quando tinham as oportunidades de produzirem suas respectivas escritas literárias, tiveram que copiar ou imitar os mestres europeus, chegando assim a uma sintonia com o pensamento de Manuel Ferreira: "no escritor movem-se valores do colonizador que são dados adquiridos, funcionam valores culturais de origem e há sempre a consciência de valores que se perderam e que é necessário ressuscitar" (1989, p. 34). A segunda fase é a da resistência. Nessa etapa, o escritor africano assume a responsabilidade de ser defensor da cultura africana. Essa fase serve como ruptura da estética da produção literária europeia. É importante associar essa fase à da negritude lusófona.

A terceira fase é a fase da pós-independência, quando o escritor africano procura marcar o seu lugar na sociedade, pois preocupa-se com a definição da sua posição nas sociedades já independentes em que vive. Por fim, a quarta $e$ última fase seria a fase contemporânea; isto é, a fase em que os escritores dessa geração procuram traçar os novos rumos para o futuro da literatura dentro das coordenadas de cada país, ao mesmo tempo em que se esforçam para garantir suas literaturas nacionais.

De acordo com Amílcar Cabral, "a literatura é um componente da cultura que, capturando as percepções e experiências quotidianas coletivas, pode ajudar a produzir um sentimento forte de identidade nacional” (1978, p. 9). Para Sebastião Marques Cardoso, "os autores de língua portuguesa que se destacaram na literatura pós-colonial são, sobretudo, autores que, de algum modo, apresentaram algum tipo de vínculo com a luta de libertação" (2017, p. 362). Esses escritores assumiram o papel de expressar os desencantos provocados pelos seus conterrâneos. Na opinião de Trigo (1985, p. 471), as literaturas africanas são fruto da emergência de vozes silenciadas, empenhadas em conquistar a dignidade individual e social. Sendo assim, a literatura guineense é parte da história do seu povo e da sua luta cotidiana.

Acredita-se que, dentre os países africanos de língua oficial portuguesa, Guiné-Bissau é o país onde a literatura se desenvolveu mais tardiamente. Para Filomena Embaló, isso é "devido ao atraso do aparecimento de condições socioculturais propícias ao surgimento de vocações literárias" ${ }^{10}$. Esse atraso também tem como origem a tardia implantação do processo de ensino no país

${ }^{10}$ EMBALÓ, Filomena (2004). Breve Resenha sobre a Literatura da Guiné-Bissau. Disponível em Google: www.didinho.org/arquivo/resenhaliteratura.html. Acesso: 05/03/2021. 
pelos portugueses, que, desde sempre, apenas mantinham interesses na exploração de recursos.

Dessa forma, percebe-se que a literatura guineense ganhou mais destaque por meio daqueles que lutaram contra o regime colonial português e que ela ainda continua em busca de liberdade e da afirmação da identidade do povo guineense. É uma literatura em resistência: resistência contra questões surgidas no período da independência; resistência contra questões surgidas no período pós-independência.

Jorge Otinta, numas das entrevistas concedidas em 2016 à estudante Maira Augusto Badinca, ressaltou "que a literatura guineense nasceu tal como o país sob o signo do fogo, ou seja, sob o napalm" ${ }^{11}$. Em vista disso, trata-se, sem dúvida, de uma "literatura militante, engajada, comprometida com a causa da libertação nacional". Seu objetivo é garantir que o país se constitua "em novas identidades plurais". Essa literatura começou a ser desenvolvida na primeira metade do século XX e ganhou força na segunda metade do mesmo século, com os escritos de António Baticã e Vasco Cabral, considerados como os maiores escritores desse período.

De 1970 até 1990, destacam-se os nomes de Conduto de Pina, Abdulai Silá, Agnelo Regalla, Conduto de Pina, Domingas Samy, Félix Sigá, Filinto de Barros, Odete Costa Semedo, Tony Tcheka, etc. De lá para cá tivemos ainda outros escritores, como Manuela Costa, Saliatu da Costa, Jorge Otinta, Rui Jorge Semedo, Edilson Ferreira, etc. Na visão desses escritores, a literatura é uma arma discursiva, que serve, entre outras coisas, para romper com os impasses políticos e sociais guineense e que representa vozes plurais das tradições de várias etnias dessa sociedade, como sublinhou o pesquisador e crítico literário Jorge Otinta.

Nas obras literárias guineenses, a linguagem é retomada como espaço para recuperação do sujeito como ser histórico e social. Para isso, os diálogos entre textos, entre tempos e espaços, entre a tradição e a modernidade são a chave para o entendimento das obras.

O novo sistema governativo que as novas elites assumiram e implantaram após a independência na Guiné-Bissau demonstra uma situação de desigualdade social profunda, que acarreta a luta pela sobrevivência. Esse regime complexo, de algum modo, permite aos escritores guineenses do pós-

11 OTINTA, Jorge de Nascimento Nonato. Literatura Guineense. [Entrevista concedida a] BADINCA, Mairra Augusto In: Feito três pedras de fogão: afirmação da identidade nacional sob o olhar dos escritores guineenses. Repositorio Unilab, p. 08. Redenção, 2017. Disponível em: Maira Augusto Badinca.pdf (unilab.edu.br). Acesso: 15/10/2020. 
independência a possibilidade de problematizar os caminhos da revolução. Ao discutir questões sociais e políticas, a literatura guineense impulsiona os seus escritores a refletirem sobre o sistema colonial e sobre as "representações dos valores" imaginários, os quais submeteram os colonizados à força (FANON, 2005, p. 54). Trata-se de uma literatura com o desejo da liberdade, conforme destaca Moema Augel:

Os autores guineenses da pós-independência, empenhando-se em glorificar a revolução e homenagear os heróis nacionais, optam por uma poesia encomiástica e encorajadora, colocando seus versos a serviço primeiro da revolução e mesmo do partido revolucionário, durante muito tempo quase sinônimos um do outro, e depois da nação (1998, p. 98).

Dessa maneira, os escritores dessa época apresentam-se como críticos sociais, denunciando os desmandos governamentais dos seus conterrâneos, refletindo a partir da noção de que "a nação é passível de ser reinventada como 'patrimônio herdado do passado' por agentes sociais que se vão apoderando dela, privatizando os signos que conferem existência às entidades fundacionais - a tradição, o passado, a memória, a língua" (MATA, 2007, p. 35). Entre esses autores, destacamos Filinto de Barros como artista e intelectual engajado e compromissado, que busca questionar, no exercício da ficção, no romance Kikia Matcho, a desigualdade social.

\title{
2.3
}

\section{Memória, identidade e cultura na sociedade pós-moderna}

\begin{abstract}
Somos todos, no fundo, feitos de areia! (MANA TCHAMBÚ). Quantos há que sabem onde se encontra esse caminho de areia no meio de areia?
\end{abstract}

Filinto Barros

A memória, além de ser uma faculdade individual, é também um processo coletivo e seletivo, assentado no desejo de recordar aquilo que se considera importante para a coletividade, fazendo assim emergir uma formação identitária a partir dessas experiências coletivas. Desse modo, a memória pode representar, na consciência, um sentimento de identidade, permitindo identificar diferentes grupos sociais, demarcando seus possíveis pontos de encontro.

Pode-se dizer que nas obras analisadas nesta dissertação, $A$ geração utopia e Kikia Matcho, a memória tem a função de perpetuar o que foi vivido. Ela 
procura recuperar os diversos processos internos que constituem a história de Angola e da Guiné-Bissau. Por causa disso, é fundamental destacar o papel da literatura nesse processo. Embora as imagens e os espaços produzidos pela literatura não sejam reais, eles permitem que o autor expresse opiniões e críticas de forma mais livre, trazendo percepções diferentes sobre o espaço em que está inserido.

O crítico literário brasileiro Alfredo Bosi afirma que "a literatura, com ser ficção, resiste à mentira. É nesse horizonte que o espaço da literatura, considerado em geral como o lugar da fantasia, pode ser o lugar da verdade mais exigente" (2002, p. 135). É com essa perspectiva que nos alinhamos quando decidimos por conectar alguma cronologia política guineense e angolana à prática ficcional. Exatamente por concordarmos com a possibilidade de criação de "um lugar da verdade mais exigente", propusemos-nos a desenvolver este trabalho.

$\mathrm{Na}$ perspectiva desta dissertação, a memória, recuperada pela ficção, permite mostrar diferentes tempos históricos por meio dos diferentes pontos de vista de personagens que viveram o jugo colonial, a luta pela independência, os momentos da pós-independência e o período dos conflitos e da guerra civil, acontecimentos que deixaram marcas profundas nas populações angolana e guineense.

Henri Bergson estabelece uma comparação entre memória coletiva e memória individual. A característica individual da memória de cada ser humano associa-se a imagens e a lembranças particulares, pois "intercala o passado [indivíduo] no [seu] presente" (1999, p. 77). Já a memória coletiva é "formada a partir de influências do meio social no qual o indivíduo está inserido" (ibidem).

Para Bergson, lembrar não é reviver, e sim refazer, reconstruir, repensar, com imagens e ideias de hoje, as experiências do passado. Assim, em sua perspectiva, a memória individual seria um ponto de vista sobre a memória coletiva, criada a partir do reconhecimento do indivíduo nas relações sociais. Maurice Halbwachs, por sua vez, defende que na memória não há um vazio absoluto. A seu ver,

(...) o passado permanece inteiramente dentro de nossa memória, tal como foi para nós; porém alguns obstáculos, em particular o comportamento de nosso cérebro, impedem que evoquemos dele todas as partes (...) não subsistem em alguma galeria subterrânea de nosso pensamento imagens completamente prontas, mas na sociedade, onde estão todas as indicações necessárias para reconstruir tais partes do nosso passado as quais nos representamos de modo incompleto ou indistinto. (...) na realidade o que tomávamos por um espaço vazio não passava de uma região pouco definida, da qual nosso pensamento se 
desviava, porque nela encontrava poucos vestígios. Uma vez que nos indiquem com precisão o caminho que temos que seguir, esses traços se evidenciam, os ligamos um ao outro. (...) Então eles existem, porém eram mais marcantes na memória dos outros do que em nós mesmos (1990, p. 77).

Diante da ideia de Halbwachs, entende-se que a memória estimula a vida atual do ser humano, principalmente por intermédio das relações sociais, pois a situação presente é que nos faz lembrar, como considera Ecléa Bosi. Na visão da autora, "a lembrança é uma imagem construída pelos materiais que estão, agora, à nossa disposição, no conjunto de representações que povoam nossa consciência atual" (2001, p. 55). Para Ecléa, a memória tem um papel importante na conservação do passado, sobretudo quando os "guardiões da tradição" (os mais velhos) nos ensinam o retrato da memória coletiva de um lugar. A memória coletiva, então, cria um sentimento de pertencimento. Ela produz um despertar de consciência para nossas tradições, reafirmando uma identidade coletiva.

Ainda de acordo com a autora, a linguagem é o instrumento transformador da memória, independente de como ela é apresentada; "as convenções verbais produzidas em sociedade constituem o quadro ao mesmo tempo mais elementar e mais estável da memória coletiva" (BOSI, 2001, p. 56).

De acordo com Sueli Saraiva, a narrativa literária encontra-se em dois planos fundamentais: "o plano da história relatada e o plano do discurso que a relata" (2016, p. 29). Assim, pode-se dizer que "a narrativa se estrutura em função de certo devir temporal: do presente para o passado e deste de novo em direção ao presente" (idem, p. 30). Esse devir temporal, revelado no interior da narrativa, obedece a certos "padrões de sucessividade que descrevem o espaço onde se desenrola ação e a caracterização das personagens" (ibidem). Entendemos que a temporalidade que estrutura as narrativas africanas em análise nesta dissertação se configura "no fenômeno de sucessão de estado e transformação" (ibid.). Desse modo, a memória, em A geração da utopia e em Kikia Matcho, procura analisar acontecimentos político-sociais tomando como ponto de partida o processo de resistência e denunciando as condições de vida dos povos analisados nesses romances.

De acordo com Stuart Hall,

A identidade é realmente algo formado, ao longo do tempo, através de processos inconscientes, e não algo inato, existente na consciência no momento do nascimento. Existe sempre algo 'imaginário' ou fantasiado sobre a sua unidade. Ela permanece sempre incompleta, está sempre 'em processo', sempre sendo formada (2006, p. 38). 
Hall complementa que a identidade pode ser percebida como um conjunto de aspectos identitários que surgem do "pertencimento" - das culturas étnicas, raciais, linguísticas, religiosas e, sobretudo, nacionais. Mas quando esses fenômenos entram em declínio, significa que estamos perdendo algo, algo que nos leva imediatamente ao que poderíamos chamar de "crise de identidade". Desse modo, "a identidade somente se torna uma questão quando está em crise, quando algo que se supõe como fixo, coerente e estável é deslocado da dúvida da incerteza", como observa Kobena Mercer (MERCER apud HALL, 2006, p. 9).

Abordar a questão da identidade cultural na sociedade colonial pressupõe falar do sujeito que ali se encontrava: o "homem branco", europeu, e o homem "negro", africano, o colonizador português e os colonizados africanos, sujeitos com identidades e culturas diferentes. Dois mundos diametralmente opostos. $\mathrm{O}$ mundo do colonizador se pautava pela imposição cultural enquanto o mundo do colonizado procurava resistir a essa imposição. Evidentemente, o choque entre os dois mundos provocava inúmeras tensões permanentes.

Benedict Anderson defende que o conceito de identidade nacional se apoia na ficção e por vezes representa um sentimento de nacionalidade e de pertencimento a uma determinada comunidade ou grupo social. Ele afirma que a comunidade "é imaginada porque mesmo os membros da mais minúscula das nações jamais conhecerão ou sequer ouvirão falar da maioria de seus companheiros, embora todos tenham em mente a imagem viva da comunhão entre eles" (2008, p. 32). Ruy Duarte de Carvalho defende que

\footnotetext{
A identidade coletiva, quer a nível nacional, quer a nível parcelar, faz-se, ou, diria eu, produz-se no âmbito de uma dinâmica que se opera, inventa e reproduz no dia a dia, na sequência dos acontecimentos, das respostas, das resistências, das alianças e das dependências estratégicas (1997, p. 129).
}

Ruy Duarte de Carvalho enaltece uma das frases que Amílcar Cabral usava e que dizia assim: "quem se preocupa com as identidades culturais são as pessoas que precisamente perderam ou de algum modo temem em assumir o que lhes pertencem" (CABRAL apud CARVALHO, idem, p 131). Assim, é o povo que serve de referência para a identidade cultural.

A identidade não apenas é uma relação de igualdade aplicável para a cidadania ou para o pertencimento a um dado país, mas também envolve outros fatores, como a religião, o sexo, a cor partidária, entre outros aspectos. São inúmeros os exemplos e as personagens que poderíamos retirar dos romances 
A geração da utopia e Kikia Matcho que atestam a ideia de comunidade imaginada.

A formação do sentimento nacional e da identidade nacional em Angola, segundo Manuel Ferreira, é parte de um sentimento regional "que vai dar lugar [...] a uma literatura alimentada já por uma verdadeira consciência nacional e daí a uma literatura africana, caracterizada pelos pressupostos de intervenção" (1977, p. 34). Nos casos de Angola e da Guiné-Bissau, identificamos isso na poesia produzida entre 1951 e 1974 e vemos que isso foi reforçado, após a independência, por outros gêneros literários, como o conto e o romance.

De modo igual, no campo da memória, acrescenta-se a necessidade de uma "depuração", pois "não se trata de um regresso ao tempo que procedeu à cisão para recuperar na totalidade os signos daquela ordem cultural", e sim "de resgatar alguns dos referentes que se podem integrar aos tempos que se seguem" (CHAVES, 2004, p. 160).

A memória e a(s) identidade(s) podem resgatar as vivências de uma determinada sociedade e transformás-la em matéria de ficção. Por conta disso, é possível verificar que existe uma relação que se estabelece entre os conceitos de identidade e de memória a respeito da formação identitária do ser humano e, consequentemente, da formação da sua subjetividade. Vale ainda considerar a afirmação do sociólogo português Boaventura de Sousa Santos, que sugere que a formação das identidades em "tempos de globalização" se move pelo "direito de sermos iguais quando a diferença nos inferioriza e de sermos diferentes quando a igualdade nos descaracteriza" (2002, p. 75). Rita Chaves, ao retomar sua pesquisa sobre os escritores africanos, especialmente os angolanos, demonstra como a ruptura política se aplica também à cultura angolana. Assim, diz ela:

O desejo de construção de uma identidade nacional que sela a configuração do sistema literário em Angola explica, então, a relevância que se dá ao espaço no repertório de seus autores, justificadamente preocupados com a necessidade de simbolicamente realizarem a apropriação do território invadido (CHAVES, 2004, pp. 160-161).

Ainda sobre cultura, Carlos Lopes realça que:

O entendimento da cultura de um lugar é necessário para poder ancorar o processo de transformação. A existência de uma ética própria serve para aumentar o sentido de comunidade e de autoestima, fatores entre os mais valorizados na capacitação dos indivíduos, instituições e sociedades. Em tempos de imprevisibilidade, o recurso à discussão ética era sinal de valorização e autoestima (2005, p. 50). 
Para concluir, afirmamos que, se entendermos a cultura como um conjunto de valores éticos e comportamentais que moldam uma determinada sociedade, sociedade em que as pessoas partilham as mesmas crenças e ideais, os mesmos usos e costumes, então podemos afirmar que a identidade é uma espécie de referência que torna os seres humanos aquilo que eles são. A identidade é aquilo que define os seres humanos como membros de uma determinada comunidade. 


\title{
ANGOLA E GUINÉ-BISSAU: UMA POSSIBILIDADE DE COMPARAÇÃO
}

\begin{abstract}
Não foram anunciados, nem tão pouco desejados, mas os camaleões chegaram. E chegaram todos de uma vez. Apressados. Poderosos e violentos.
\end{abstract}

Abdulai Silá

Neste capítulo, pretendemos fazer uma análise comparativa dos processos de construção do estado-nação em Angola e Guiné-Bissau. Para isso, decidimos averiguar os conflitos políticos e sociais que surgiram nos últimos anos nesses dois países.

A fase de transição política, com vistas à declaração da independência em Angola e Guiné-Bissau, constitui-se em certos protestos protagonizados por seus conterrâneos. Alguns desses homens em protesto perceberam que os rumos tomados após a independência poderiam causar graves consequências para o desenvolvimento de ambas as nações, e essa situação acabou por dar origem, mais tarde, a guerras civis. É de salientar ainda que, para a retirada dos colonizadores portugueses, e, por conseguinte, para o estabelecimento de um Estado independente, houve guerras sangrentas, que envolveram o Estado português num lado e o MPLA e o PAIGC no outro.

Como se sabe, o Estado guineense encontrava-se em condições bastante críticas em termos institucionais. Como atesta o relatório da Africa Report citado por Sérgio Manuel Dundão (2014, p. 6), "a Guiné-Bissau precisa de um Estado. As suas estruturas políticas e administrativas são insuficientes para garantir o controlo do seu território". De acordo com Tcherno Djaló,

\begin{abstract}
A história contemporânea da Guiné-Bissau tem sido uma sucessão de actos de violência política institucional que marcam profundamente a memória colectiva do seu povo, influenciando duma certa forma a sua cultura política. Independentemente das causas ou das ideias defendidas por cada movimento político, é de constatar que as grandes rupturas políticas desse país se fizeram não na base negocial e de compromisso, mas na de violência política $(2000, p$. 29).
\end{abstract}

Os conflitos internos não permitiram a emergência dos estados-nações de Angola e da Guiné-Bissau, e, segundo Herbst, "as lutas de libertação nacional 
para a conquista da independência" (1990, p. 128) criaram um sentimento provocado pelo "trauma da guerra" que resultou num tipo de "nacionalismo que não é capaz de tornar o estado-nação realidade" (ibidem).

Esse mesmo trauma acarretou, entre 1980 e 2012, quatro golpes de Estado em Bissau. Em Guiné-Bissau, após o golpe protagonizado por João Bernardo Vieira (Nino Vieira) em 14 de novembro de 1980, o conflito abriu caminho para a ascensão de militares guineenses que depois derrubaram o próprio presidente Nino Vieira, como no evento de 7 de junho de 1988, conhecido como a Guerra de 7 de junho.

O golpe de estado de 14 de novembro de 1980 é fruto do descontentamento de Nino Vieira com a introdução de patentes militares no seio das Forças Armadas em meados de 1979. Insatisfeito, Nino Vieira conduziu o golpe de estado contra o governo de origem cabo-verdiana de Luís Cabral, que era dirigente do PAIGC.

Para alguns pesquisadores, o 14 de novembro de 1980 é uma espécie de prolongamento da fragmentação do Estado guineense entre 1970-1973, fragmentação que deu origem à morte do líder Amílcar Cabral, na medida em que abriu brechas dentro do partido. Fafali Koudawo \& Peter Karibe Mendy apontam que

\begin{abstract}
Uma das justificativas do golpe de Estado de 14 de Novembro de 1980 foi aparentemente "o desvio da linha de Amílcar Cabral", cuja implicação econômica era o abandono da estratégia de desenvolvimento de orientação socialista que dava prioridade ao melhoramento e à modernização da agricultura. Com isso, um ano depois do golpe, no primeiro congresso extraordinário do PAIGC realizado em Bissau de 8 a 14 de novembro, os novos governantes anunciaram que, como "herdeiros de Amílcar Cabral", continuariam a "edificação de uma política nacional independente, no quadro de uma sociedade sem exploração do homem pelo homem" (1996, p. 38).
\end{abstract}

Em seguida, deu-se o caso de 17 de outubro $1985^{12}$, data em que foram fuzilados vários lideres políticos, inclusive o ex-vice-presidente do Conselho de Estado, o Coronel Paulo Correia. Diante desse fenômeno de violência política e humana, percebe-se também que a instabilidade governativa atingiu fortemente a viabilização das políticas públicas que ajudariam a minimizar as mazelas da pobreza e a garantir a liberdade de expressão. Como observa Carlos Cardoso,

\footnotetext{
${ }^{12}$ Em 17 de outubro de 1985, vários oficiais das FARP (Forças Armadas Revolucionárias do Povo) foram detidos em Bissau acusados de preparar um golpe de Estado contra o Presidente João Bernardo Vieira.
} 
Os acontecimentos de outubro de 1985 abalaram profundamente a imagem do PAIGC não só no plano externo, como também, e fundamentalmente, no plano interno. Para além de ser reforçada a sua legitimidade perante o povo - que agora mais do que nunca se tinha apercebido das divisões no seio do partido, que perdeu muitos militantes, na sua maioria pertencentes a etnia balanta, fato que só se dá conta no momento em que autoriza formalmente a constituição da oposição (1996, p. 29).

Assim, percebe-se que o 7 de junho de 1988 decorreu da crise da política do PAIGC e da crise no seio das Forças Armadas. O fato de não terem sido discutidos os problemas militares durante a realização do VI Congresso do PAIGC foi um dos motivos pelos quais emergiu um clima de grande tensão e de preocupação dentro do partido.

A guerra de 7 de junho, liderada pelo brigadeiro Ansumane Mané (antigo chefe do Estado-Maior), possibilitou também a ocorrência de outros golpes de Estado, como o de 14 de setembro de 2003, no qual Veríssimo Correia Seabra derrubou Kumba Yalá. Após esse conflito, Kumba Yalá foi eleito presidente em fevereiro de 2000 e governou até setembro de 2003, período em que sofreu um novo golpe de estado. Nesse momento, o comando militar nomeou Henrique Rosa como presidente interino de 28 de setembro de 2003 a 1 de outubro de 2005. Neste ano, Nino Vieira foi reeleito e prosseguiu governando o país até 2 de março de 2009, data em que foi assassinado por militares. Também nesse mesmo ano foi assassinado o chefe do Estado-Maior do Exército, general Tagmé Na Wai, em um atentado com explosivos. Em seguida, temos o caso de 12 de abril de 2012, que gerou uma revolta em que o "comando militar" invadiu à força a residência do primeiro-ministro Carlos Gomes Júnior, destituindo-o junto com o presidente interino, Raimundo Pereira.

É importante acentuar que, na Guiné-Bissau, as Forças Armadas continuam a sobrepor-se às ordens dos dirigentes políticos e constituem ameaça considerável à paz e à segurança que o povo guineense sempre almeja, o que causa um impacto considerável na comunidade internacional. Por esse motivo, a Organização das Nações Unidas (ONU) sempre aplica sanções para alguns representantes das Forças Armadas, para políticos e para o Estado guineense.

Ocorre que a maioria dos projetos que visam a contribuir para a reestruturação e o desenvolvimento da sociedade Bissau-guineense depende de ajuda financeira da comunidade internacional. Desse modo, o país continua a ser dependente do exterior não somente em termos econômicos e financeiros, mas também em termos políticos, sociais, institucionais e militares. Nesse sentido, as organizações da sociedade civil juntamente com a Liga dos Direitos 
Humanos vêm cobrando de diversos governos uma rápida intervenção nessa direção.

É muito importante que os militares guineenses entendam que são úteis e que podem contribuir para a melhor estabilidade política e social do país, cumprindo com suas funções e deixando a política para os políticos e para os governantes; afinal, numa democracia, política é coisa de políticos, e não de militares.

É necessário que haja, no âmago dos políticos guineenses, vontade de construção de um Estado de Direito e de fortificação das instituições, de modo a que se constra uma democracia com base nos princípios e nas especificidades que rodeiam o país. Também é preciso que haja o respeito pelas normas constitucionais, de forma a permitir a construção de um verdadeiro Estado de Direito, onde os militares devem obedecer ao poder civil democraticamente eleito, sem interferir no governo.

No caso de Angola, o processo de independência foi muito complexo. Além de intricados fatores internos, sobretudo graves divergências étnicas e culturais, houve ainda interferência externa dos países aliados por questões ideológicas e por interesses econômico. Esses países buscavam explorar os recursos humanos e naturais do país - especialmente o petróleo.

Assim, pode-se dizer que a ocupação colonial nasce dos interesses econômicos e apresenta visões antagônicas sobre os colonizados. Juvenal Carvalho (2006, p. 224) afirma que as nações europeias sempre tiveram intenção de explorar os povos colonizados através da imposição das diferenças nesses espaços. Nos espaços coloniais, reuniam povos inimigos e separavam grupos aliados, para evitar reações organizadas.

A razão da guerra civil em Angola já estava colocada antes mesmo da luta contra o colonialismo português. A disputa entre os três principais grupos nacionalistas do país leva-nos, inicialmente, à seguinte questão: se já se tinha combatido e vencido o colonialismo português, por que razão os impasses sociopolíticos e étnicos continuaram a reinar em Angola? Sobre essa questão, Cascudo argumenta que,

Após quatro séculos de domínio sobre Angola, após criar, em África, as bases de uma civilização e de uma cultura ocidentais, após vencer as barreiras do tempo e das distâncias, Portugal deixava a terra que colonizou pela porta dos fundos, numa pequena lancha, que transportava o Sr. Alto-Comissário para bordo de uma fragata, na baía de Luanda, onde ainda tremulava, palidamente, na popa, a bandeira portuguesa (1979, p. 130). 
Após a luta contra o colonialismo, os três grupos que atuaram nessa luta passaram a ter divergências em relação ao controle do país, principalmente em relação ao controle da capital Luanda. Os grupos eram o MPLA (Movimento Popular de Libertação de Angola), liderado por Agostinho Neto, a FNLA (Frente Nacional de Libertação de Angola), chefiada por Holden Roberto, e a UNITA (União Nacional para a Independência Total de Angola), comandada por Jonas Savimbi. Cada grupo detinha o apoio de uma nação estrangeira, como demonstra Max Altman $^{13}$ :

\begin{abstract}
A União Soviética e principalmente Cuba apoiavam o MPLA, que controlava a capital e algumas regiões da costa, em especial Lobito e Benguela. Os cubanos não tardaram em desembarcar em Angola em 5 de outubro de 1975. A África do Sul do apartheid apoiava a UNITA, tendo invadido Angola em 9 de agosto de 1975. A FNLA contava também com o apoio da China, de mercenários portugueses e ingleses e até da África do Sul. Os Estados Unidos, que apoiaram inicialmente apenas a FNLA, não tardaram a ajudar também a UNITA. Esse apoio se manteve até 1993. A sua estratégia foi durante muito tempo dividir Angola.
\end{abstract}

Podemos compreender o nacionalismo como princípio unificador do período pré-independência dotado de uma "estratégia de resistência e acumulação de uniformidades". Uma dessas estratégias era pautada no desejo de que angolanos, guineenses e demais povos africanos que viveram a violência colonizadora não tivessem dificuldades de encontrar os rumos para o desenvolvimento social. Trata-se de desafio que está sendo superado a cada dia, pois, como afirma Homi Bhabha, "a nação preenche o vazio deixado pelo desenraizamento de comunidades e parentescos" (1998, p. 199).

Essa afirmação leva-nos a compreender a importância da nação para a convivência social e para busca de unidade e de proteção coletiva; só que, para que as coisas sejam assim, os espaços comunitários devem estar abertos a ideias novas e a novos indivíduos. Devem ser espaços que acolham as diferenças, espaços em que as diferenças façam parte da construção. O nacionalismo representado em $A$ geração da utopia, do escritor angolano Pepetela, serviu de justificativa para as diferenças e de ilustração das consequências dos conflitos do pós-independência, conflitos cuja resolução tardou - e ainda tarda - a se consolidar.

Chatterjee (1996) ressalta que, com o passar dos anos, vários movimentos surgidos nas lutas contra o colonialismo na África acabaram por implantar

13 ALTMAN, Max. Hoje na História: 1975 - MPLA proclama a independência de Angola. Disponível em: http://operamundi.uol.com.br. Acesso em 24/01/2021. 
regimes desfavoráveis às populações. Esses regimes tornaram-se antidemocráticos, uma vez que privilegiam uns poucos e não fazem quase nada para diminuir a pobreza massiva existente nos países africanos desde a era da colonização. A euforia e a esperança das populações foram suscitadas pelo sentimento vigente no processo de consolidação da paz durante a luta anticolonial. Acontece que as falhas provenientes da guerra civil não são fáceis de ser superadas. Elas acabaram colocando em suspeita a capacidade de governo dos atuais dirigentes. Elas acabaram apontando para suas incapacidades no processo de desenvolvimento de uma nação - nação imbuída de um espírito nacionalista que deveria resolver as questões divergentes por meio do debate democrático.

Chatterjee, citando Benedict Anderson, apresenta uma visão dos nacionalismos na África e na Ásia que teria sido modelada pela noção de nacionalismo compreendida na Rússia, nos Estados Unidos e nos países da Europa ocidental. Com base nesses modelos de nacionalismo, os líderes das nações africanas recém-independentes acabaram escolhendo o modelo que melhor Ihes convinha, e isso gerou graves consequências, que afetaram muitos países africanos. Uma tal interpretação do nacionalismo desembocou em violência; e os casos de Angola e da Guiné-Bissau estão aí para comprovar isso.

Para concluir, como vimos, o processo de desenvolvimento de Angola, assim como o de Guiné-Bissau, foi dificultado por fatos que têm origem na colonização e nas lutas pela independência e, sobretudo, pelo longo período de guerras civis. Embora esses países possuam muitas riquezas, riquezas que podem acarretar o tão esperado desenvolvimento socioeconômico, eles vêm sucumbindo a guerras internas. E as guerras trouxeram a desgraça social, política e econômica. Trouxeram a fome, o desgoverno, o abandono da população. Em suma, as guerras trouxeram o caos sociopolítico para Angola e para Guiné-Bissau. É por isso que os processos de reconstrução nacional dos dois países são lentos - muito lentos.

\section{1}

\section{Angola: uma perspectiva de reconstrução nacional}

Angola situa-se nas regiões Austral e Central do continente africano e possui uma superfície total de $1.246 .700 \mathrm{~km} 2$. O país faz fronteira ao Norte com 
a República Democrática do Congo, por vezes chamada de RDC ou de República do Congo; ao Sul com a República da Namíbia; e a Leste com a República da Zâmbia. Além disso, é banhado pelo oceano Atlântico na parte Oeste e possui uma população estimada em cerca de treze milhões de habitantes. O seu território corresponde a uma costa marítima de $1.650 \mathrm{~km}$, enquanto o seu território terrestre tem a extensão de $4.837 \mathrm{~km}$. Angola tem um solo rico em petróleos e diamantes, entre outros recursos minerais, e possui terrenos férteis para agricultura, em que se destacam as produções de café, algodão e cana-de-açúcar, conforme salienta Ukuma (2005, p. 107).

A República de Angola foi colônia portuguesa durante cinco séculos. Como sabemos, sob o pretexto de promover a fé cristã e de contribuir para o progresso da humanidade e da civilização, Portugal foi o primeiro país europeu a começar a exploração e a conquista do além-mar. Acontece que as coisas não se resumiam a isso na prática.

Na prática, Portugal tinha outros propósitos na África, propósitos velados, como a exploração de riquezas e de mão-de-obra locais. Para piorar, o país ainda buscava estabelecer um sistema de alienação cultural, com o objetivo de dominar as mentes africanas. Assim, estabeleciam trocas de produtos locais borracha, cera, marfim - por produtos europeus - bebidas e tecidos -, numa espécie de intercâmbio que também se dava entre recursos humanos e recursos naturais, de um lado, e "valores" supostamente superiores, associados à modernidade de cariz iluminista e eurocêntrica, de outro. Durante esse processo de trocas, milhares de africanos foram forçosamente enviados para a Europa e a América como escravos.

A expansão colonial em Angola, assim como em Cabo-Verde, GuinéBissau e São-Tomé e Príncipe não foi pacífica, nem tinha como ser, uma vez que as missões portuguesas enviadas a esses países visavam a explorar suas populações. Muitas vezes, essas missões viam-se obrigadas a negociar com as autoridades locais, que obrigavam certas pessoas a partirem para realização de trabalhos forçados na Europa.

Toda essa situação provocou a revolta de movimentos de intelectuais africanos oriundos desses países a partir das décadas de 1940-1950. Esses movimentos ansiavam por despertar consciências para a necessidade de lutas de libertação nacional. É nesse momento que o nacionalismo começa a emergir por meio da multiplicação de ações políticas e culturais de angolanos, guineenses, entre outros. 
Em 4 de Fevereiro de 1961, iniciou-se a Luta Armada de Libertação Nacional em Angola, que perdurou por treze anos. O país só veio a alcançar a independência em 11 de Novembro de 1975, apesar de encontrar-se então dividido entre o Governo da República Popular de Angola, de um lado, e o movimento rebelde UNITA, de outro.

Para a construção de uma nação justa e transparente, todos os angolanos deveriam ter dado o máximo de si; porém muitos acabaram perderam o rumo. A realização de uma tarefa dessa magnitude implicava a interiorização de novos valores e a correção de velhas práticas, permitindo que novas atitudes pudessem formular e reformular ações políticas, ações que deveriam voltar-se para a convivência social e para o desenvolvimento econômico, político, industrial, tecnológico e cultural do país.

É importante ressaltar que tanto Angola quanto Guiné-Bissau buscaram consensos que pudessem servir de base de entendimento para o desenvolvimento das nações africanas. Aliás, ações que pretendem unir diferentes partidos políticos do mosaico desses Estados buscam estimular o trabalho em conjunto para o desenvolvimento de cada nação e para a realização de eleições em clima de paz, concórdia e estabilidade.

A figura da autoridade tradicional é muito relevante para a consolidação da democracia e da Unidade Nacional em Angola; afinal, a experiências dos nossos velhos "têm sido de grande valia na resolução dos problemas do país e do nosso povo" (UKUMA, idem, p. 109). É urgente pensarmos no futuro promissor do nosso país, defendendo nossos interesses políticos, econômicos, sociais e culturais - isso também serve para Guiné-Bissau. Essa tarefa requer dos angolanos e dos guineenses um trabalho árduo para alcançar os nossos objetivos e para diminuir os índices de pobreza e das endemias no seio das nossas populações.

A conquista da independência em Angola é resultado de sacrifícios de numerosos filhos dessa pátria. Os heróis da luta anticolonial e toda população angolana merecem viver em boas condições econômicas, sociais, culturais e étnicas, como ressalta Ukuma:

O sentimento pátrio de todos deve ser uma constante numa altura em que cada vez mais se busca a necessidade de voltarmos a nossa autoafirmação, a nossa autoconfiança, a nossa identidade, para que, unidos e solidários, atravessemos a longa caminhada para a reconstrução nacional da nossa querida pátria (idem, $\mathrm{p}$. 110). 
Os heróis da história patriótica angolana devem servir de inspiração para as novas gerações de Angola, motivando-as a participarem de forma ativa no projeto que visa a desenvolver o país em vários níveis. As novas gerações são fundamentais para a instauração do bem-estar social e para a consolidação de um Estado democrático de direito. As novas gerações são fundamentais para colocar Angola no seu verdadeiro lugar.

\section{2}

Filinto de Barros e Pepetela: o intelectual e sua missão perante as elites africanas

A transição da independência à democracia em Angola e em Guiné-Bissau são acontecimentos recentes, como vimos. Após as guerras anticoloniais, entre as décadas de 1960 e 1970, a queda do muro de Berlim, em 1989, e a dissolução da União Soviética impactaram fortemente as relações dos dois países recém-independentes com as potências do norte.

Acreditamos que é necessário levar em consideração dois aspectos importantes nesse cenário. Por um lado, deve-se estimular a implementação de um projeto de construção de unidade nacional baseado numa ideologia de identidade política, uma vez que já não se trata mais de democracia revolucionária. Por outro lado, as elites políticas e intelectuais locais devem assumir compromissos em defesa de regras consideradas válidas, em defesa de normas constitucionais que disciplinem a participação dos atores políticos e na vida pública.

De acordo com Edward Said, o colonialismo, do ponto de vista da exploração humana, foi "sustentado e talvez impelido por potentes formações ideológicas que incluem a noção de que certos territórios e povos precisam e imploram pela dominação" (1995, p. 40). Essa ideologia alicerçava-se num argumento que pressupunha a crença em uma superioridade do colonizador, que detinha o dever de civilização e de salvação das almas dos povos colonizados.

O princípio do sistema colonial português, de um modo geral, baseou-se nessa crença, isto é, na premissa de uma superioridade europeia branca em relação às populações nativas. A exigência de inserção econômica no sistema produtivo europeu apoiava-se no fundamento de que as colônias tinham um dever de produzir riquezas, dever que, de certa forma, seria uma espécie de 
"contrapartida" a benefícios obtidos com o desenvolvimento, o progresso e a civilização moderna. Ocorre que a relação colonial estava sustentada no uso da força, da violência e da exclusão. As práticas coloniais, ocultadas nos discursos oficiais sobre os processos coloniais, baseavam-se na submissão e na destruição cultural e religiosa africana, em favor, evidentemente, de crenças e práticas católicas.

No plano concreto da vida cotidiana do homem comum, as relações humanas e sociais, definidas no quadro do colonialismo, são condicionadas por um aparato que Homi Bhabha observa como algo que

\begin{abstract}
Se apoia no reconhecimento e no repúdio de diferenças raciais, culturais, históricas, e busca a [...] legitimação para suas estratégias através da produção de conhecimento do colonizador e do colonizado como uma população de tipos degenerados com base na origem racial, de modo a justificar a conquista e a estabelecer sistemas administrativos e instrução (1998, p. 111).
\end{abstract}

Desde o início da colonização em Angola e em Guiné-Bissau, a educação colonial portuguesa depreciava as culturas tradicionais desses nações, o que se demonstra claramente com a proibição da utilização das línguas africanas nas escolas e com a inscrição, desde o ambiente escolar, de um sentimento de inferioridade da identidade africana. Para Amílcar Cabral, nas escolas, "a geografia, a história e a cultura de África não são mencionadas ou são adulteradas, e a criança é obrigada a estudar a geografia e a história portuguesa" (1978, p.64). Essa imposição pedagógica e curricular faz com que as crianças das colônias portuguesas na África adquiram uma sensação de déficit cultural intransponível, refletido pela escola desde o início de sua formação. É válido afirmar que o homem africano era sempre caracterizado e apresentado como inferior em relação ao homem branco; por isso

as libertações, as independências nacionais, não devolvem, nem poderiam devolver 0 poder às sociedades, às nações, às configurações políticas précoloniais [...] a esses, a história passou-lhes necessariamente por cima [...] já não existem (CARVALHO, 2011, p.90).

Segundo Fanon, a Igreja Católica teve papel relevante na colonização, pois sua ação missionária voltava-se para conduzir o colonizado "ao caminho do branco, do amo, do opressor" (FANON apud CHAVES, 2005, pp. 38-39), e não ao caminho de Deus. Em razão dessa premissa do processo colonial europeu, quando o colonizado descobre sua humanidade, começa "a polir as suas armas, 
para as fazer triunfar" (ibidem). Em outra perspectiva, o colonizador descobre que

[...] a sua respiração, as pulsações do seu coração, são as mesmas que as do colono. Descobre que uma pele do colono não vale mais do que uma pele do indígena. Deve dizer-se que essa descoberta introduz uma agitação essencial no mundo. Toda a segurança nova revolucionária do colonizado dimana disso (ibid.).

Segundo Amílcar Cabral, é impossível pensar em um movimento de luta de libertação que não tenha como base o objetivo de destruir o regime colonial e a opressão que lhe é peculiar:

O instrumento essencial da dominação imperialista é a violência. [Portanto] Se aceitamos o princípio de que a 'liberdade nacional' é uma revolução e de que ela não acaba no momento em que se iça a bandeira e se toca o hino nacional, veremos que não há nem pode haver 'liberdade nacional' sem o uso da violência libertadora por parte das forças nacionalistas, para responder à violência criminosa dos agentes do imperialismo (1978, p. 211).

As características locais da dominação imperialista implicam então um estado de violência permanente contra as forças nacionalistas. Diante de um tal cenário,

[...] o que importa é determinar quais as formas de violência que devem ser utilizadas pelas forças de libertação nacional, para que não só respondam à violência do imperialismo, mas também para que garantam, através da luta, a vitória final da sua causa, isto é, a verdadeira independência nacional (ibidem).

O atual sistema político de Angola e da Guiné-Bissau parece reproduzir o modelo da colonização portuguesa, pois é construído na base da política da metrópole:

Partindo então de valores e referências culturais exteriores às sociedades africanas e da crença de superioridade em todos os aspectos da 'civilização' europeia: o colonialismo traz consigo o terror. É verdade. Mas traz também consigo, ainda mais nefasto talvez que o chicote dos exploradores, o desprezo ao homem, o ódio ao homem, enfim, o racismo. Que o consideremos como melhor nos convém, chegaremos sempre à mesma conclusão. Não há colonialismo sem racismo. (CÉSAIRE apud BALANCHARD \& BANCEL, 1998, p. 34).

Essa crítica evidencia mecanismos de poder de matriz ocidental, configurados por meio de processos coloniais reproduzidos pelas elites nacionais, que constroem, muitas vezes, o mesmo ângulo de visão dos antigos poderes coloniais. Essas elites, preparadas para o propósito de interferir nos processos políticos nacionais, terminam por representar uma simples 
substituição de protagonistas no quadro das instituições políticas e dos dispositivos de controle do governo.

Os desdobramentos históricos dessas tensões políticas e socioeconômicas marcaram a passagem do sistema e dos discursos coloniais à tomada de voz dos colonizados. O escritor e antropólogo Ruy Duarte de Carvalho expõe uma crítica a respeito dos novos rumos da democracia tomados pelo Estado Angolano. Ao demonstrar preocupação "com as chamadas democracias modernas, cujo modelo foi imposto pelo Ocidente, aos processos e às práticas inerentes à Angola contemporânea" (FISCHGOLD, 2019, p. 198), Ruy Duarte de Carvalho identifica a formação das elites políticas atuais na transição do período da independência para o da pós-independência.

Desse modo, a narrativa dos escritores angolanos funda-se a partir de um projeto político, ideológico e revolucionário que indica que "o itinerário do angolano na busca de minar os bloqueios impostos pelo colonialismo inscrevese como a própria história da palavra em Angola" (CHAVES, 1999, p. 33).

Para José Carlos Venâncio, um novo sistema de democracia conhecido como "angolanidade" também constitui um quadro de "substrato sócio-histórico fornecido pelo colonialismo português que figurava como vector de integração das culturas africanas e europeias" (1993, p. 16). Em Angola, os escritores assumiram o papel de expressar desencantamentos provocados pelos novos rumos políticos. Sobre os escritores angolanos, José Carlos Venâncio afirma que "os seus textos deixam de ser veículos de preocupações de índole puramente cultural para passarem a transmitir as preocupações políticas dos seus atores e porventura potenciais leitores" (VENÂNCIO, 1992, p. 8). A partir desse contexto, o político jamais deixará de ser o tema dominante da literatura africana.

$\mathrm{Na}$ Guiné-Bissau, a independência, além de provocar transformações nos campos social e político, também implicou o rompimento com a literatura trazida pelo colonizador português. Homi Bhabha afirma que os escritores africanos atuam com seus discursos na direção de uma "autenticação das histórias de exploração" (1998, p.26). Nesse contexto, podemos situar as obras de Abdulai Silá, Filinto de Barros e outros autores que tratam da representação da sociedade guineense.

A vontade de forjar uma nova identidade nacional levou os escritores e poetas a desenvolverem, com base na recuperação de elementos históricos, uma poesia "genuinamente" guineense. As antologias Mantenhas para quem luta! e Antologia dos jovens poetas, além de narrarem a história da jovem nação, representam a gênese de um sistema literário guineense. Essas duas obras, 
precursoras do sistema literário guineense, refletem a conexão entre cultura, literatura, língua e identidade, aspectos comuns nas chamadas literaturas emergentes.

Pepetela, ao discutir questões sociais, políticas e econômicas, provoca o leitor a lembrar dos envelhecidos projetos de construção de uma sociedade justa e igualitária, já que a esperança e a utopia de uma sociedade livre após a independência deram lugar a desilusões e incertezas. Nessa perspectiva, as páginas do romance $A$ geração da utopia constituem um espaço dramático de denúncia e de inconformismo, como se pode ver no excerto abaixo:

\begin{abstract}
O colonialista é colonialista, acabou. Dele não há nada a esperar. Mas de nós? O povo esperava tudo de nós, prometemos-lhe o paraíso na terra, a liberdade, a vida tranquila do amanhã. Falamos sempre no amanhã. Ontem era a noite escura do colonialismo, hoje é o sofrimento da guerra, mas amanhã será o paraíso. Um amanhã que nunca vem, um hoje eterno. Tão eterno que o povo esquece 0 passado e diz que ontem era melhor que hoje. (PEPETELA, 2000, p. 143).
\end{abstract}

O trecho a seguir ilustra o sentimento de fragmentação e de inutilidade da guerra. Com bases nas ideias que pareciam ser tão resistentes na década anterior, podemos ver como esse sentimento é confirmado na fala da personagem Aníbal:

\begin{abstract}
O que dizes, no fundo, é o mesmo que estou a dizer. Não digo que a luta contra o colonialismo é absurda, mas o caminho que a guerra tomou é absurdo. Olha para os guerrilheiros. São hoje uns foragidos, quase mercenários, já nada têm de combatentes revolucionários, nada, absolutamente nada. Qual é o problema principal para eles? A mulher que foi dormir com outro, a miúda que está a crescer e que todos disputam, o ndoka que ainda não está pronto, aquele que comeu mais carne que eu. E quando há qualquer coisa, a desculpa é o tribalismo, o regionalismo (idem, p. 150).
\end{abstract}

No trecho abaixo, o narrador do romance apresenta os princípios da revolução que aconteceria em Angola após a luta pela independência. Um exemplo disso é quando Marta, personagem do romance, relata à Sara a desilusão que Aníbal experimentou no processo de libertação:

A tal revolução que tem à frente não vai ser como ele imagina. Nunca nenhuma é como os sonhos dos sonhadores. É um sonhador, apesar de toda a sua linguagem rigorosa de comunista. Acaba por ter ideias mais libertárias que as minhas, que ele chamava de anarquista. As revoluções são para libertar e libertam quando têm sucesso. Mas por um instante apenas. No instante a seguir se esgotam. E tornam-se cadáveres putrefactos que os ditos revolucionários carregam às costas toda a vida (idem, p. 113). 
Aníbal representa jovens angolanos integralmente dedicados à causa da independência de seu país. Como se pode ver, a literatura angolana surge como arma de combate, como instrumento de afirmação do homem angolano.

A formação de uma nova geração de intelectuais em Angola, sobretudo a partir dos anos de 1940, permitiu o aparecimento da intensa produção literária e crítica contra o colonialismo português. Assim, a escrita funciona, no campo cultural, como uma arma de combate que busca afirmar a identidade do homem angolano. $\mathrm{Na}$ época colonial, com a formação de uma diferença nacional em relação ao colonizador, a escrita passou a abrir espaço para crítica e para o registro da desilusão em relação ao novo estado político e social que se formava no país. A literatura de Pepetela, desse modo, ao recuperar a incômoda experiência colonial e as estratégias de combate, está inserida no tempo e no espaço.

O comprometimento que a literatura possui com a história de Angola encaixa-se na busca da compreensão da sociedade e da política angolana. É por isso que o romance $A$ geração da utopia procura retomar questões centrais da construção do Estado angolano. Ao explorarem processos históricos recentes, Pepetela e outros escritores contribuíram muito para a construção de pensamentos críticos aos regimes instaurados a partir da independência.

Outra questão digna de nota refere-se à transição do sistema político unipartidário para o sistema multipartidário em Angola, fator que é apontado na narrativa de Pepetela em forma de crítica aos rumos tomados pelos novos dirigentes políticos, bem como pela nova elite econômica do país. Mais tarde, Angola ainda seria afetada pela corrupção, o que demonstrava que a utopia revolucionária estava sendo corroída pela desigualdade existente no país.

É importante ainda destacar que o MPLA, apesar de ter tido muito mérito na formação do estado-nação angolano, teve lá suas falhas também, pois contribuiu com o fracasso no fortalecimento de um modelo democrático que descentralizasse o poder e permitisse a liberdade de expressão para o povo angolano. Christine Messiant ressalta que, mesmo após a inauguração do sistema multipartidário, não houve transição para a democracia em Angola. Em termos políticos, o Estado angolano, até hoje, encontra-se numa situação de grande tensão política, e "o que se impõe na prática como modo de acesso aos bens e serviços é, pois, o modo clientelista, e não a reivindicação de direitos própria a uma democracia" (2006, p. 147).

Para compreendermos os aspectos políticos que se desenvolveram no período pós-independência em Angola, devemos olhar atentamente para os 
sistemas políticos que foram implantados no país. Via de regra, o que veremos é uma relação entre Estado e sociedade que não é nem um pouco vantajosa para o povo.

Patrik Chabal argumenta que os principais problemas enfrentados pelos africanos quanto ao exercício do poder estão relacionados às "complexas formas em que a sociedade e a política interagem" (CHABAL apud SOUZA, 2019, p. 194). Sabendo que o "poder formal" se concentra no Estado e que o "poder informal" se baseia em relações "clientelistas e patrimoniais", verifica-se que a mesclagem dessas práticas forma o sistema político africano. Para Chabal, esse é um debate de fundo para a compreensão da legitimação do estado africano contemporâneo.

No caso de Angola e da Guiné-Bissau, não é possível afirmar que houve uma ruptura total com o Estado colonial; afinal, mesmo com a independência política proclamada pelos dois Estados nacionais, houve uma permanência dramática do sistema político colonial nas estruturas de poder e nas relações sociais. O que se verifica então é uma estrutura de poder única, que controla todas as relações do poder tradicional e econômico dessas sociedades e que permite a indesejada ascendência de determinados atores políticos que se colocam como intermediários entre a riqueza e o poder político.

Para Patrick Chabal (2009), as transformações ocorridas no aparelho de Estado angolano, assim como no contexto guineense, fracassaram na produção de uma transformação sistêmica que reforçasse a institucionalização, da mesma forma que não possibilitaram um desenvolvimento democrático que abrisse espaço para o reconhecimento da sociedade civil. Assim, os governantes controlam os recursos do país e deles dispõem, de modo a garantir a legitimidade e o apoio necessários para permanecerem no poder. Muito disso é tematizado no romance $A$ geração da utopia, o qual constitui uma importante fonte histórica acerca da sociedade angolana.

Já o escritor e político guineense Filinto de Barros, em Kikia Matcho, resgata, por meio do silêncio, as suas histórias e queixas da sua pátria, focalizando os heróis que são "entregues ao alcoolismo e à frustração" - ao desalento do combatente. $O$ escritor como guerrilheiro testemunha a realidade da luta de libertação na Guiné-Bissau, a realidade política posterior ao período pós-independência e a situação dos guineenses em Portugal, analisando os impasses e os desafios da atualidade política e sociocultural dos guineenses.

Filinto de Barros também assinala a imensa distância que separa os excombatentes dos atuais dirigentes da nação, examinando os rumos que foram 
tomados na condução do país e os motivos que produziram a modificação do poder. O narrador pergunta: "Quem não desertou dos caminhos traçados por Cabral? Que diferença entre este desertor da Luta e aqueles que elegeram o enriquecimento ilícito à custa do povo de Cabral como a forma mais refinada da deserção?" (1999, pp. 80-81). Isso demonstra a insatisfação dos veteranos, e o sentimento patriótico da história é posto em xeque no desenrolar do romance.

Do ponto de vista histórico, o romance Kikia Matcho enfatiza a situação social e política da Guiné-Bissau, e o desfecho do livro leva-nos a sentir a atmosfera negativa do país. O aparecimento surpreendente de kikia parece confirmar o destino guineense. Mesmo após a guerra civil de 7 de Junho, o país continua mergulhado em índices econômicos e sociais medíocres, com sucessivas tensões políticas.

Filinto de Barros cria um narrador que facilita o deslocamento espacial e temporal da narrativa. Ele conta a história de Joana em Portugal e, ao mesmo tempo, narra a presença de Benaf e de Papai durante a realização da cerimônia fúnebre do ex-combatente N'dingui Có em Bissau. A sua voz narrativa revela não apenas a euforia com a expulsão dos colonizadores, mas também os momentos de grande tristeza daqueles que protagonizaram essa luta, o que chega a fazer uma das personagens exclamar: "não te esqueças de que chefe é chefe" (BARROS, 1999, p. 134). A justificativa dessa exclamação, nas palavras de Augel, seria "a falta de reação ou protesto por parte do povo" (2007, p. 294).

O trecho acima confirma o que vimos falando da vida cotidiana dos chefes, diretores, dirigentes e políticos que comandam a sociedade guineense. Segundo o narrador de Kikia Matcho, "no serviço passou a reinar a incompetência de tudo menos do assunto". Os recém-formados estavam "amarrados nas suas próprias contradições, sem poder conciliar a realidade da luta com a nova realidade dum país carente de recursos humanos capazes" (BARROS, 1999, p. 20).

É possível notar a insatisfação e as críticas feitas pelo autor por meio do uso de metáforas, começando com os efeitos do "Ajustamento Estrutural"14, exaltado pela política de desenvolvimento em 1986, passando pela reforma

cf. Segundo Faustino Imbali (IMBALI apud OTINTA, 2010, p. 3), o Programa de Ajustamento Estrutural visava, segundo as partes signatárias - o governo guineense e as instituições de Bretton Woods - ao desenvolvimento da Guiné-Bissau como uma das metas a atingir com a estabilização da economia e a melhoria nas condições de vida da população. Apesar disso, a bem da verdade, o ajustamento foi imposto ao governo de Bissau como solução para problemas estruturais existentes: déficit público, economia de subsistência, má governança, certa desorganização dos tecidos sociais e políticos de um Estado fragilizado, que, por um lado, teve de lidar com as restrições à obtenção de empréstimos e de ajudas e, por outro, com os políticos guineenses, que não se coibiram do exercício da corrupção, do clientelismo e do neopatrimonialismo como estratégia para o enriquecimento fácil. 
política de 1994 e encerrando com a integração do país na Comunidade Francófona $^{15}$.

Assim sendo, Filinto de Barros direciona seu texto para a construção da ideia de nação e de nacionalidade guineense, propondo, na ficção, uma "abordagem do processo de síntese sociocultural" do povo guineense.

O personagem Papai, depois de se conformar com o que recebia do Estado, depois de tantas desilusões, decepções e promessas, sem ver nada se concretizar, acaba por se acostumar a ouvir e a aceitar os mesmos discursos repetitivos, até quando, indignado, exclama:

Nós recebemos pouco, enquanto os comandantes estão cheios de carros e de comadres, por todo os lados. No mato éramos iguais. [...] Os chefes hoje pensam mais nas suas contas bancárias e nos seus filhos no estrangeiro! Os amigos dos nossos chefes hoje são outra gente! Nem sequer se lembram de nós, (BARROS, 1999, p. 118).

Por atuarem como intelectuais em seus respectivos países, Filinto de Barros e Pepetela procuram colocar em suas construções narrativas as denúncias que o intelectual engajado, na perspectiva de Said, Benda e Gramsci, deve fazer sobre os desvios tomados pelos dirigentes políticos de suas nações. Desse modo, a relevância de seus romances não está somente no desnudamento das relações de poder que se desenvolvem entre o Estado e a sociedade, mas também se encontra na representação do universo mais amplo das relações sociais. Os projetos literários de Filinto de Barros e de Pepetela também apresentam as submissões interpostas nas suas sociedades diariamente, até os dias atuais. As obras estão ligadas diretamente, em estreito diálogo, pelas relações de poder que descortinam, estabelecidas em ambas as nações no período pós-independência. Por essas razões, marcam as profundas contradições presentes nessas sociedades - sociedades marcadas pela corrupção política.

É pertinente destacar que, por mais que os discursos políticos, em Angola e na Guiné-Bissau, tenham sido pautados em valores como a democracia e a liberdade, ainda são evidentes nesses países as marcas da permanência de uma cultura política de opressão e de marginalização. Mesmo após as inúmeras mudanças ocorridas nos dois países, nota-se que os partidos e os dirigentes políticos vão adequando seus comportamentos de acordo com transformações

\footnotetext{
${ }^{15}$ Os países membros da UEMOA (União Econômica e Monetária do Oeste Africano ) são: Benim, Burkina Faso, Costa do Marfim, Guiné-Bissau, Mali, Níger, Senegal e Togo. A entrada oficial da Guiné-Bissau na zona CFA deu-se no dia 2 de Maio de 1997, data em que começaram a ser substituídos os pesos guineenses por francos CFA.
} 
que viabilizem e reproduzam os seus próprios interesses políticos. Se examinarmos os personagens dos romances em análise, veremos que a constatação dessa denúncia pesa dramaticamente na materialidade da vida social e política em Angola e na Guiné Bissau.

Assim, o intelectual é aquele que tem sempre em mente a consciência crítica de qualquer opressão, corrupção, desvio e marginalização numa determinada sociedade. Em concordância com Edward Said, a função do intelectual remete ao "intelectual como um outsider, um 'amador' e um perturbador do status quo" (SAID, 2005, p. 10). O intelectual então é quem vai defender os espaços públicos, a pureza das ideias e os ideais de justiça.

Em síntese, o silêncio dos marginalizados, sobreposto por vozes das elites angolanas e guineenses dominantes, pode ser quebrado por meio da produção literária de escritoras e de escritores. A construção da revolução, da autoconsciência e da autodeterminação impõem inúmeras responsabilidades ao futuro do país. Todo o vasto campo da cultura e mesmo a literatura possuem um papel a desempenhar nesse sentido. A literatura, em particular e há muitas décadas, constitui uma das bases de reação às visões colonialistas de mundo.

\section{3}

\section{Personagens, foco narrativo, tempo e espaço: em $\boldsymbol{A}$ geração da utopia e em Kikia Matcho}

Nossa intenção, a partir de agora, é fazer uma análise comparativa entre os romances $A$ geração da utopia e Kikia Matcho, para entender como seus elementos estéticos (personagens, foco narrativo, tempo e espaço) desempenham um papel importante para a compreensão de algumas questões problematizadas nessas narrativas. É por meio das diversas personagens das duas obras, por exemplo, que vamos compreender de forma metafórica o universo de miséria, exclusão, pobreza, fome, violência e indignação presentes na vida das populações angolana e guineense em tempos atuais.

A fundamentação teórica que utilizaremos neste percurso analítico, interpretativo e argumentativo começa com Tania Franco Carvalhal (2006) e com a noção de literatura comparada.

Segundo essa pesquisadora, a leitura comparativa de textos literários produzidos em diferentes contextos nacionais favorece a reflexão sobre a 
identidade nacional, cultural e literária e privilegia a existência de diferentes espaços literários com características próprias e distintas. Assim,

A crença de que há nos textos literários elementos comuns que identificam a sua natureza, sem que isso os uniformize, é que ampara a atuação não só da teoria literária como da literatura comparada quando ambas visam à abstracção de conceitos a partir da análise textual, orientando-se para aspectos supraindividuais das obras (CARVALHAL, 2006, p. 125).

A pesquisadora defende que, apesar de a expressão "literatura comparada" ser utilizada no singular, ela é compreendida necessariamente no plural, pois implica um método de investigação que confronta duas ou mais obras literárias, ocupando-se das relações literárias estabelecidas entre dois ou mais textos e autores. O objetivo principal dos estudos comparativos é o de compartilhar um diálogo, estabelecendo relações entre diferentes épocas, ambientes e espaços, evidenciando a interação dinâmica que provém do reconhecimento dessas diferenças. Desse modo,

\begin{abstract}
Pode dizer-se, então, que a literatura comparada compara não pelo procedimento em si, mas porque, como recurso analítico e interpretativo, a comparação possibilita a esse tipo de estudo literário uma exploração adequada dos seus campos de trabalho e o alcance dos objetivos a que se propõe (idem, p. 08).
\end{abstract}

Também Aguiar \& Silva afirmam que a intertextualidade é "uma caraterística essencial de todos os textos verbais" (1976, p. 214), pois é um elemento muito importante para estudos comparativos. O intertexto é "um texto (ou um corpus) de textos que existe antes e debaixo de um determinado texto e que, em amplitude e modalidades várias, se pode "ler", decifrar, sob a estrutura de superfície deste último"(ibidem). Carlos Reis afirma que

O conceito de intertextualidade estabelece-se a partir de uma concepção dinâmica do texto literário, entidade situada num vasto universo textual (que abarca tanto os textos literários como os não literários), funcionando como espaço de diálogo, troca e interpretação constantes de uns textos noutros textos (2002, p. 185).

A intertextualidade enriquece a narrativa porque permite o estabelecimento de diálogos com outros textos, ampliando a rede de significados e de conteúdos das obras em diálogo.

A geração da utopia é um romance que tem como pano de fundo a história recente de Angola: as lutas anticoloniais iniciadas na década de 1960, a conquista da independência na década de 1970 e o período da pósindependência nos anos 1990 até os dias atuais. A narrativa de Pepetela 
funciona como um ponto de partida para uma análise contemporânea da história angolana, destacando o papel dos intelectuais no processo de construção do estado-nação.

Há capítulos importantes no romance que abordam etapas específicas da história de Angola, como "A casa" (1961), "A chana" (1972), "O polvo" (abril de 1982), "O templo" (a partir de julho de 1991). No primeiro capitulo, o narrador apresenta fatos que ocorreram em 1961, ano em que começaram as lutas de independência em Angola. Parte-se da Casa dos Estudantes do Império (CEI), em Lisboa, Portugal, onde um grupo de estudantes angolanos discute os rumos que devem ser tomados para a conquista da independência. Nesse momento, "o ambiente estava cada vez mais pesado e as notícias de Angola eram só de prisões, mesmo de intelectuais" (PEPETELA, 2000, p. 78). Segundo o narrador,

Tudo começa em 15 de Março. Não, antes. Em 4 de fevereiro, houve ataques às prisões de Luanda, para libertar os presos políticos. Seguiu-se uma repressão terrível em Luanda, falava-se de milhares de mortos entre os nacionalistas. Aí também mistério, quem executara as acções, qual seu objetivo? Depois foi Março no Norte. Um levantamento contra os brancos, os fazendeiros de café eram mortos e as povoações, saqueadas. Era pelo menos essa a propaganda do governo (idem, pp. 8-9).

A juventude no romance é representada pelos personagens de Aníbal, Elias, Horácio, Laurindo, Sara e Vitor. A relação do escritor Pepetela com a Casa dos Estudantes do Império, onde ele estudava em Portugal, é lembrada por Luiz Maria Veiga:

O jovem Artur Pestana [Pepetela]. [...] também passou a frequentar a Casa dos Estudantes do Império, onde moravam e se reuniam outros jovens de diferentes colônias, parte deles envolvidos nos projetos políticos de independência. Pepetela já sabia, desde Angola, dessa fama de CEI, mal vista e pouco recomendada pelos familiares dos estudantes que iam para Portugal. Num caso típico de conflito de gerações, esse acabou sendo um dos motivos que o atraiu para o lugar. Lá conheceu camaradas que viriam, como ele, a participar da luta de guerrilha contra as forças colonialistas (2015, p. 67).

Assim, a parte inicial do romance se passa em Lisboa, na Casa dos Estudantes do Império, motivo por que o primeiro capítulo recebe o título de "A casa". A CEI "foi o cantinho da saudade, o ponto de encontro com a terra distante" (MATA, 2018, p. 10) e permitiu "que não poucos estudantes africanos pudessem manter o equilíbrio psíquico, algumas vezes ameaçado pela violência do desenraizamento e sobretudo pela descoberta das condições tão particulares do racismo português" (MARGARIDO apud MATA, 2018, p. 15). 
A CEI foi uma referência importante na luta contra a ditadura. Alguns de seus membros tonaram-se alvos de punição e de perseguição e foram interceptados e presos pela PIDE. Além disso, vivendo em Lisboa, eram vítimas de exclusão e de preconceitos de toda a natureza, inclusive linguístico. Conforme relata o narrador de $A$ geração da utopia,

A situação está séria. Muita repressão, a PIDE anda doida. Devem estar a fazer inquéritos e mais inquéritos sobre a Casa. Neste momento deve ser o alvo principal deles. Conversas mais sérias, não convém tê-las nem na Casa nem no Rialva (PEPETELA, 2000, p. 13).

Essa passagem aponta para os abusos que os estudantes da CEI enfrentavam naquele momento. A situação era tão complicada que quase todos os membros eram "apontados a dedo nos cafés, nos cinemas, na rua. Traziam na cara os estigmas que os denunciavam como potenciais terroristas" (idem, $\mathrm{p}$. $5)$.

No segundo capitulo, "A Chana", vemos que o leste de Angola é o campo da luta anticolonial e que as personagens são os guerrilheiros principais. Descobrimos a problemática da guerra por meio do guerrilheiro Aníbal, o sábio, que andava sozinho e sofrido no deserto já no final das batalhas. Essa viagem pela Chana representa a distopia dos que lutaram e a travessia por que passaram. Sobre a Chana, o narrador afirma que ela "não é um deserto, nada tem de comum com um deserto. O deserto é um mundo fechado. A Chana são vários mundos fechados, atravessados uns pelos outros. A complexidade da Chana está na sua própria definição" (idem, p. 122).

Para Veiga, "A Chana" representa os "guerrilheiros em fuga, famintos e isolados, descontentes com a direção ou em disputas de carácter regionalista ou tribalista" (2015, p. 19). Rita Chaves, ao comparar o romance A geração da utopia com Mayombe, ambos escritos por Pepetela, afirma que

Radicalizando alguns sinais captados nas matas do Mayombe, aqui [em "A chana"] é perfeitamente possível detectar as contradições e insuficiências que levariam aos desvios do projeto em parte tão alimentado em "A casa" [...]. O desencanto parece chegar antes do fim da guerra de libertação, e o discurso do narrador não oculta o sentimento de frustração a prenunciar a descrença. [...] $O$ projeto de uma nação livre se vai estilhaçando na condução de um processo inicialmente banhado pela generosidade de um sonho coletivo (2005, pp.100-101).

Sendo assim, a utopia, o projeto de construção de uma nação, encontra como adversários os próprios homens que investiam em sua construção. Podemos então afirmar, em concordância com a professora Rita Chaves, "que o 
texto literário se transforma [...] num espaço não só do registro da crise", mas do exercício de uma reflexão; "nesse compasso, o romance, em seus recursos estruturais, projeta a crise que é a marca da sua época" (idem, p. 137).

O terceiro capítulo, "O polvo", passa-se em 1982, já nos tempos de guerra civil em Angola. A imagem do polvo é estrategicamente acionada na narrativa como forma de demonstrar a irresponsabilidade social e a corrupção marcada pela sociedade angolana. O polvo, na cultura africana, representa a ligação entre o passado e o presente. Metaforicamente, a morte do polvo representa não apenas a morte dos guerrilheiros revolucionários e sonhadores, mas também a morte da utopia e da esperança do povo angolano. O polvo assinala então a transformação de um sonho utópico na realidade mesquinha dos jogos de poder, o momento em que os novos líderes deixavam os planos revolucionários de lado e começavam a defender interesses particulares e egoístas. Era o fim da utopia - "A utopia morreu. E hoje cheira mal, como qualquer corpo em putrefacção. Dela só resta um discurso vazio" (PEPETELA, 2000, p. 207).

No terceiro capítulo do romance, o narrador descreve como a imagem simbólica de um polvo gigante persegue o imaginário do comandante Aníbal. As cisões entre o passado e as contingências do presente provocam no sábio uma reflexão acerca "de um passado de quimeras que trouxe este presente absurdo" (idem, p. 198). Assim,

[...] um Estado que se comporta como pai e filho tem de lhe contar tudo, já não tem direito à privacidade. As pessoas... não são pessoas, são apenas os cargos que ocupam no aparelho do Estado. Não há lugar para sentimentos, relações humanas; há apenas relações de poder. Os homens deixaram de ser homens, com suas virtudes e seus defeitos, são apenas cadeiras cômodas, são máquinas, parafusos, bens que se utilizam. Ou máquinas mais complexas que se servem desses bens. Essas pessoas de que falas, não são pessoas, Sara, são o Estado, o sistema (idem, p. 215).

A instabilidade política que se vive em Angola enquadra-se em um contexto específico de conflitos de alguns países da colônia portuguesa, nos quais as divisões estabelecidas pela via da força têm sido o calcanhar de Aquiles da evolução política, econômica, social e cultural, como atestam os casos da Guiné-Bissau e de Moçambique.

No último capítulo de A geração da utopia, "O templo", vemos eventos que se passam a partir de julho de 1991, ocasião do fim da guerra civil em Angola, que fora iniciada em 1976, logo após a independência. Em o "O templo", nota-se que $o$ antigo combatente Mundial agora virou um homem importante: um ministro do novo Estado. Após a independência, a corrupção em Angola e em Guiné- 
Bissau tornou-se a marca mais visível dos novos governantes no aparelho do Estado.

A passagem do tempo em $A$ geração da utopia fica explícita na permanência de um modelo político marcado por um autoritarismo que nem mesmo as transições políticas foram capazes de eliminar. Podemos levar em consideração dois momentos importantes para a análise do romance de Pepetela. O primeiro refere-se aos primeiros tempos da escrita do romance, ao início do ano de 1985, momento em que Angola está passando por transformações profundas, sobretudo no que diz respeito aos ideais socialistas, que começaram a ser deixados por trás poucos anos após a independência. Já o segundo se refere à transição do sistema político unipartidário para o sistema multipartidário, fator que é apontado na narrativa de Pepetela em forma de crítica aos rumos tomados pelos novos dirigentes políticos e pela nova elite econômica, que se formaram com o surgimento do Estado angolano e que se afudariam em corrupção, afetando profundamente os rumos de Angola. Como salienta Rita Chaves, a utopia revolucionária estava sendo corroída pela desigualdade existente no país:

\footnotetext{
O tempo correu, a luta pela independência política se fez e o inimigo comum foi derrotado; todavia levantaram-se os fantasmas previstos e mais aqueles que não se fizeram prever. O leitor depara-se com uma sociedade marcada pela corrupção, pela falta de escrúpulos, pela irresponsabilidade social. [...] Aníbal, orientado pelo seu desencanto, retira-se para a praia da Caotinha (2005, pp. 101102).
}

Esse trecho mostra como Pepetela retrata experiências concretas das populações angolanas, experiências em que a frustação das utopias deram espaço a um presente desencantado e distópico. Desse modo, é possível apontar, em seu romance, a preocupação com o realismo se evidencia num olhar atento sobre os fatos políticos e sociais das sociedades pósindependência.

Em $A$ geração da utopia, o espaço em que se desenrolam as ações é constituído pelos locais de convivência, como a casa e o templo, locais que descrevem Angola em todas as suas contradições e incertezas do pósindependência.

Sobre a questão da representação do espaço na literatura, Luis Alberto Brandão defende que, na construção narrativa, os espaços são apresentados com o propósito de chamar atenção para a impossibilidade de dissociar a percepção das personagens da realidade vivida no mundo. Assim, "a intenção 
não é se contrapor à existência concreta dos espaços relatados, mas dar-lhes relevância no construto dos acontecimentos que envolvem a narrativa" (2013, p. 68) . Desse modo, o espaço da personagem numa narrativa seria

[...] um quadro de posicionamentos relativos, isto é, um quadro de coordenadas que erigem a identidade do ser exatamente como identidade relacional: o ser é porque se relaciona, a personagem existe porque ocupa espaço na narrativa (ibidem).

A narrativa de Pepetela aponta a trajetória espacial percorrida pelo personagem Aníbal, o sábio, a fim de demonstrar o desejo de uma geração que, de certo modo, sonhava como uma nação justa, igualitária e independente. Mas depois de longos anos de lutas, de conflitos e de guerra civil, depois dos desdobramentos da situação nacional, essa geração decepcionou-se o com desfecho da utopia inicial. Assim, vemos, por exemplo, como o espaço de resistência e da tomada de consciência coletiva se estabelece na luta de morte com o polvo, o que aponta para o fato de que os governantes, em vez de servirem à população, serviam os próprios líderes que estragavam Angola, que impediam o crescimento do país.

Tânia Macêdo destaca que "as marcas da história nas trilhas da ficção de Pepetela, bem como a presença de um questionamento corajoso a aspectos da conjuntura sociopolítica de seu país, podem ser acompanhadas ao longo de toda a produção literária do autor" (2009, p. 295). Um detalhe importante é o fato de que Pepetela ${ }^{16}$ foi um dos primeiros intelectuais angolanos a escrever a história pós-colonial de seu país.

Em seu romance, percebe-se que Pepetela constrói um mundo literário para abordar os momentos históricos da luta de libertação em Angola, começando pela esperança de uma nação livre, pela Casa dos Estudantes do Império, passando pela conquista da independência e terminando no desencanto do período pós-independência. O escritor moçambicano Mia Couto afirma que "Pepetela não está escrevendo sobre Angola"; ele estava "escrevendo Angola sonhada e geradora dos sonhos" (2009, p. 82).

Nascido em Moçambique, mas de origem portuguesa, Mia Couto também retratou questões semelhantes do contexto moçambicano em seus romances,

\footnotetext{
${ }^{16}$ No ano 1958, Pepetela foi estudar em Lisboa, passando a intervir na CEI, colaborando nas suas publicações. Com a luta armada de libertação nacional, em 1961, um ano depois, em 1962, ele segue para o exílio na França, acabando finalmente por passar um tempo na Argélia, que se havia tornado independente graças a uma guerra de libertação nacional. Na Argélia, Pepetela formou-se em Sociologia e, no Centro de Estudos Angolanos que os nacionalistas haviam instituído, dedicouse a escrever, com Costa Andrade e Henrique Abranches, para o MPLA, uma História da Angola, numa perspectiva resumida e revolucionária.
} 
entre os quais destacamos Um rio chamado tempo, uma casa chamada terra, publicado em 2003, no qual Couto confirma, pela via da ficção, o resultado político e social da luta de libertação moçambicana. Em Um rio chamado tempo, uma casa chamada terra, acompanhamos as trajetórias das personagens principais e nelas identificamos a idealização do projeto de nação em Moçambique e a problematização das diversas transformações ocorridas na sociedade moçambicana.

Em seu livro, Mia Couto busca preservar algumas tradições moçambicanas e o sentimento de pertencimento ao continente africano, revelando o impasse cultural, político e social da África atual. Assim, o rio, a casa e o tempo são elementos fundamentais para que se compreenda a construção da identidade africana - em especial, da moçambicana - , enquanto a chuva serve como símbolo de purificação e de pertencimento. Todos esses símbolos estão em constante movimento entre o passado e o presente, entre as problemáticas da colonização e as da pós-colonização, entre a tradição e a modernidade, entre os mortos e os vivos.

Seguindo adiante, é importante ressaltar que tanto Pepetela quanto Filinto de Barros são escritores ex-combatentes que foram excluídos dos projetos nacionais. Fieis a seus propósitos, ajudaram a construir a utopia de seus compatriotas. Não traindo seu povo, sentiram-se traídos, e isso aparece nos traços distópicos de suas obras. Desse modo, A geração da utopia e Kikia Matcho são trabalhos militantes e revolucionários.

Kikia matcho é um pequeno exercício de ficção. "Nem história, nem sociologia, nem etnologia, nem política, tão somente uma abordagem que se pretende dinâmica do processo sóciocultural de um povo", conforme é destacado na epígrafe do romance. Em sua narrativa, o escritor e crítico literário guineense Filinto de Barros procura questionar o Estado guineense em face da corrupção política na época pós-colonial, levando em consideração que a maioria dos homens que integram a classe política nacional atual advêm da frente da luta pela libertação.

O autor, por meio de seu pequeno exercício de ficção romanesca, aponta para a desigualdade social do seu país. Jorge Otinta diz que "é possível afirmar que o romance dispõe-se a dialogar com a realidade na medida em que a própria experiência do autor, Filinto de Barros, como guerrilheiro e intelectual, parece contribuir para as cenas que se organizam ao longo do romance" (2011, p. 235). É um pouco isso que transparece em Kikia Matcho, com as diferenças 
entre Benaf, Joana e Papai. Filinto de Barros apresenta suas personagens com as características de um intelectual orgânico, ou seja, de um intelectual que se

Empenha com todo o seu ser no senso crítico, na recusa em aceitar fórmulas fáceis, clichês prontos ou confirmações afáveis, sempre tão conciliadoras sobre o que os poderosos ou convencionais têm a dizer e sobre o que fazem. Não apenas relutando de modo passivo, mas desejando ativamente dizer isso em público, (SAID, 2005, pp. 35-36).

Desse modo, é possível dizer que o romance dialoga com a experiência do autor como escritor, intelectual e guerrilheiro. A nosso ver, um intelectual é alguém que consegue fazer perguntas fundamentais voltadas para a vida em sociedade, para a vida de seu tempo. Um intelectual é alguém que não apenas levanta questões, mas que também fornece respostas. É alguém que, ao menos, é capaz de ensair respostas.

Frantz Fanon, ao discutir questões sociais, políticas e culturais do pósindependência em sociedades africanas, afirmou que havia nessas sociedades uma relação desigual, de exclusão social e de desunião. O que ocorre no período pós-independência corresponde àquilo que afirmávamos ser a substituição de uma espécie de homem por outra: a substituição do colonizador europeu pelo colonizador interno. A personagem Na Birisni, em Kikia Matcho, testemunha as mudanças ocorridas nesses tempos e que produzim impactos até hoje. Diz ela:

\begin{abstract}
Sabemos que as coisas mudaram muito hoje em dia! Sabemos que o Mundo já não é tão 'malgós' [sagrado] como dantes! Os miúdos foram à guerra para correr com os 'brancos'! Nós preparamos o 'caminho' aos nossos filhos para nos livrarem dos 'brancos'! Os 'brancos partiram', mas os nossos miúdos transformaram-se em 'brancos'! [...] Mas, como vês, quando há dificuldade, eles lembram-se de nós, pedem-nos a nossa ajuda porque sabem que ainda continuamos a ser os 'guardas' desta terra 'malgossadu' [sacralizado] que querem à viva força tornar "dós" [dessacralizada, profanada]. (BARROS, 1999, pp. 92-93).
\end{abstract}

Essa passagem revela a preocupação do narrador com o processo de "aculturação" dos meninos (intelectuais revolucionários) em relação aos mais velhos (os antigos combatente, os garandis da terra). Assim, dá para observar o quanto a realidade distópica invadiu tanto o mundo do colonizado quanto o do opressor. Conforme destaca o narrador, "as 'almas' mantêm a postura dos vivos. Transformam-se em seres maus, egoístas, sedentos de vingança. N'dingui Có vivo era um mimo de pessoa, mas aquela entidade que se dizia a 'alma' do seu amigo era tão diferente" (idem, pp. 114-117). 
A citação a seguir funciona como uma espécie de retrato da emergência da realização da cerimônia de Toca-Choro ${ }^{17}$ de $\mathrm{N}^{\prime}$ dingui. Com a realização da cerimônia, a pátria poderá salvar-se:

- Ainda bem que não és parvo! Mas voltamos a essa do corpo. O problema é vosso, se não se desfizeram dele, terão que aguentar com cheiros nauseabundos e doenças! 'Aqui, onde estou, ou se passa ou se regressa!'. Regressar, só duma forma! - Isso nunca, Nho Papai! Regressar deles é só como 'Kassissas ${ }^{18,}$, 'pé de cabra'! Deus nos livre de tamanha praga! - [...]

- Cruzes! Cruzes! Cruzes! 'Camarosca'! 'Figa canhota'!

(idem, p. 118)

Assim, percebe-se como a alma do ex-combatente N'dingui provoca certa preocupação na figura das personagens Tia Mana Tchambu e Papai. Filinto de Barros, numas das entrevistas realizada com o pesquisador Jorge Otinta sobre Kikia Matcho, confirma essa hipótese, acrescentando que

O livro foi uma tentativa de sintetizar fenômenos sociais, novos e velhos, que surgiram com a mudança, com o fim da era colonial. Infelizmente não fui capaz de dar continuidade ao tema principal do livro. Assim não consegui desenvolver a questão-chave da cultura no sentido lato do termo. O desafio principal para o desenvolvimento do Continente reside na definição e assumpção duma cultura própria, diferenciada e dinâmica. O continente africano tem de escolher: imitar os outros ou optar por um regresso às origens. Ao mesmo tempo e paralelamente, aproveitei para narrar, informalmente, a história da luta de libertação na sua vertente de assumpção ideológica e de choques e contradições inerentes a uma estrutura social em mutação. Penso que não consegui atingir em pleno esses objectivos, na medida em que os leitores analisam mais a vertente política (BARROS apud OTINTA, 2011, p. 45).

Filinto de Barros, bem como Pepetela, parece colocar-nos desafios para que nos apressemos a escrever e a descrever os fatos da história para as gerações vindouras, de modo a não permitir que a história vá morrendo aos poucos. A participação de Pepetela e de Filinto de Barros no processo da construção das nações angolana e guineense, respectivamente, contribuiu bastante, sem sombra de dúvida, para apontar os caminhos alternativos a respeito das ações que visem à promoção da igualdade de direitos nas duas sociedades. Gramsci afirma que

\footnotetext{
17 Segundo Otinta, Toka Tchur ou Toca-Choro "compreende todo um conjunto de cerimônias e rituais fúnebres que vão desde o abalsamamento do cadáver, vesti-lo, fazer o Djongago (perguntar à alma à causa da sua morte), ao ritual do sacrifício dos animais (vacas, porcos, cabras e galinhas) até à festa entre as mandjuadadis (grupos de pessoas de mesma faixa etária). Mas este fenômeno só é verificável nas etnias africanas não islamizadas; pois estas fazem apenas o famosos Simola (Oferenda) quarenta dias após a morte de qualquer ente falecido, com sacrifício do carneiro e comunhão da cola (uma espécie de grão de noz que eles mascam)" (2011, p. 247).

${ }^{18}$ De acordo com Filinto de Barros, kassissa significa "espírito maligno".
} 
Todo grupo social, ao nascer do terreno originário de uma função essencial do mundo da produção econômica, cria também organicamente uma ou mais camadas de intelectuais que conferem homogeneidade e consciência da própria função não apenas no campo econômico, como também no campo social e político: o empresário capitalista gera junto consigo o técnico da indústria, o cientista da economia política, o organizador de uma nova cultura, de um novo direito, etc (1996, p. 1513).

Assim, constatamos, ao longo da nossa análise, que Pepetela e Filinto de Barros, em seus romances, abordaram como se deu o processo das lutas de libertação nacional em Angola e em Guiné-Bissau e retraram as desilusões e corrupções que dão continuidade ao aumento da pobreza nesses dois países. A corrupção provocou a invisibilidade dos ex-combatentes, daqueles que deram suas vidas para que o país se tornasse livre e independente e que, segundo a personagem Papai, mereciam estátuas nas cidades. Estátuas "para dizer às gerações vindouras que têm uma identidade de cultura homogênea e diversificada da qual devem sentir-se orgulhosos!" (BARROS, 1997, p. 109). Entendemos, desse modo, que a temática do engajamento, da resistência e da denúncia expressa em $A$ geração da utopia e em Kikia Matcho continuará presente em outras obras literárias angolanas e guineenses. É a literatura servindo como arma de denúncia contra desigualdades sociais, como instrumento de luta a favor da inclusão social. 


\title{
A ESCRITA E A RESISTÊNCIA: UM PACTO ENTRE A FICÇÃO E A HISTÓRIA ANGOLANA E GUINEENSE
}

\begin{abstract}
Subsiste a ideia de que apenas os escritores africanos sofrem aquilo que se chama o "drama linguístico". É certo que a colonização trouxe traumas de identidade $e$ alienação. Mas a verdade, meus amigos, é que nenhum escritor tem ao seu dispor uma língua já feita. Todos nós temos de encontrar uma língua própria que nos revele como seres únicos e irrepetíveis.
\end{abstract}

Mia Couto

Para começarmos esta discussão, esclarecemos que consideraremos as narrativas da utopia e do desencanto como o conjunto de obras publicadas nos países africanos de língua oficial portuguesa após a independência, mas com foco em Angola e Guiné-Bissau. O período pós-independência (1974-1975) nos países analisados é muito significativo para que possamos compreender 0 processo de formação das suas literaturas, afinal, ele abrange o período de publicação de obras que deram continuidade a projetos literários iniciados pela geração antiga. Ana Mafalda Leite salienta que a África ex-colônia

\begin{abstract}
Pesa na memória portuguesa com alguma violência, particularmente experimentada nos últimos quinze anos, em que a guerra colonial antecedeu às independências. Parece haver quase uma necessidade de esquecimento da carga demasiado pesada que o processo imperial arrastou consigo. $O$ passado tende, por vezes, a ser olhado ou com algum desconhecimento - a memória é curta, e certas memórias são para esquecer - ou com uma visão mais ou menos maniqueísta, que considera apenas o sentimento de uma certa culpabilidade, e o necessário investimento de remissão dessa "culpa" histórica. Entre o culpado, que personifica a imagem do colono, e a vítima, que encena o colonizado, haverá certamente um lugar mais distanciado e, provavelmente, mais neutro, de encarar os fatos da história e da literatura (2012, p. 140).
\end{abstract}

As palavras da pesquisadora explicam de forma muito clara a condição pós-colonial e apontam, ao mesmo tempo, para as relações estabelecidas entre o sistema administrativo colonial português nos territórios ultramarinos e o sistema herdado pelos colonizados. É nessa linha de raciocínio que os escritores africanos dos PALOP, desencantados, formam as vozes com que buscarão tratar ficcionalmente as nuances dessa alegoria histórica. Um exemplo disso é 
que os narradores de Pepetela geralmente articulam suas narrativas em torno dos conflitos políticos, culturais e humanos que marcaram os processos históricos da descolonização a fim de organizar, no plano da ficção, algo que a memória oficial talvez ainda não seja capaz de fixar. Essa dinâmica, como lembra a professora Inocência Mata, busca a historicidade textual, uma vez que "a imagem do país continua a construir-se com o subsídio da literatura" (2012, p. 15). A esse respeito, a estudiosa faz, em diferentes momentos, considerações complementares. Para ela, com relação à literatura angolana, a construção literária da nação se fez especificamente por meio da poesia - e esta, de certo modo, assumiu a "coletivização da voz" para se manifestar em favor da construção de uma África livre e sem as mazelas da opressão colonialista.

De outro modo, pode-se dizer que, em Angola, Cabo Verde, Guiné-Bissau, Moçambique e São Tomé e Príncipe, o escritor africano vivia entre duas realidades das quais não podia ficar de fora: a sociedade colonial e a sociedade africana. Por isso, a escrita literária expressava a tensão existente entre esses dois mundos ao mesmo tempo em que revelava preciosas amostras dos costumes tradicionais de vários países africanos de língua portuguesa.

É nesse contexto que surgiu a literatura anticolonial de Angola e GuinéBissau, principalmente nas décadas de cinquenta e sessenta, com a missão de construir uma nacionalidade livre e transparente, mas também com o objetivo de criar uma estética nacional. Assim, compreende-se que a literatura africana de língua portuguesa vem reconhecendo, cada vez mais, a necessidade de sua contextualização histórica, sociocultural e até antropológica para que a leitura literária favoreça a análise crítica das sociedades em questão. As literaturas africanas de língua portuguesa participam de um projeto de investigação dos espaços colonial e pós-colonial que renega, com base nas experiências múltiplas do homem comum, as práticas de dominação colonial - afinal, o colonialismo procura negar a história das nações africanas, assim impedindo a sua difusão.

Mia Couto, a respeito das investigações literárias dos diversos espaços pós-coloniais, observa que "entre o pessimismo absoluto e o optismo cauteloso os retratos do continente se avolumam. Publicações diversas e extensos relatórios são produzidos para responder a qualquer coisa que, afinal, é irrespondível: 'O que é África?'” (2005, p. 79). As interpretações desse processo constituem a singularidade da nossa pós-colonialidade literária e, sinteticamente, dizem respeito a identidades nacionais que procuram englobar as identidades regionais - ou seja, as literaturas africanas intentam propor, nesses tempos 
pós-coloniais, a ligação entre identidade nacional, regional e cultural. Conforme destaca Inocência Mata,

\begin{abstract}
As literaturas africanas de língua portuguesa participam da tendência - quase um projecto - de investigar a apreensão e a tematização do espaço colonial e póscolonial e regenerar-se a partir dessa originária e contínua representação. Os significadores desse processo, que constituem a singularidade da nossa póscolonialidade literária, são potencialmente produtivos: sinteticamente dizem respeito a uma identidade nacional como uma construção a partir de negociações de sentidos de identidades regionais e segmentais e de compromisso de alteridades. $\mathrm{O}$ que as literaturas africanas intentam propor nestes tempos póscoloniais é que as identidades (nacionais, regionais, culturais, ideológicas, socioeconômicas, estéticas) gerar-se-ão da capacidade de aceitar as diferenças (2000, p. 6-7).
\end{abstract}

Escrever a história de uma nação como Angola e Guiné-Bissau, nessa perspectiva, significa elaborar a narrativa de uma cultura, de um país e de um povo, mesmo que esse tenha sido "ficcionalmente" construído para impor "processos de subjetividade", como afirma BHABHA (1991, p. 178).

Esses apontamentos demonstram a forma como Pepetela almeja, ao construir as histórias do seu país, entender os paradoxos e desencantos que qualificam ou resgatam "aquilo que é calado, que fica no subterrâneo pelo medo" (BOSI apud HELENA, 2016, p. 70). Observa-se que o autor não procurou somente narrar a história da luta armada, mas também apontar os fatos epistêmicos e culturais afetados pelo processo de apagamento capitaneado pela imposição das "histórias únicas" - processo encorpado pela rejeição da história da África e da cultura do seu povo pelos europeus, que reiteraram os seus valores através das duradouras políticas coloniais.

Para Boaventura de Sousa Santos, "a colonialidade é um dos elementos constitutivos e específicos do padrão mundial do poder capitalista, que é sustentado pela imposição de uma classificação racial/étnica da população do mundo" (2009, p. 23). Em razão disso, é possível afirmar que o pensamento ocidental representa "as manifestações do pensamento abissal" e a "distinção entre o verdadeiro e o falso" (SANTOS, 2010, p. 24). O sociólogo português acrescenta ainda que o pensamento ocidental transcende dentro de um sistema que estabelece princípios e parâmetros estruturantes de uma determinada sociedade. Nesse contexto, o outro - aquele que não faz compartilha tais princípios e parâmetros - é posto como um ser invisível, ou seja, como um ser que não pode existir. Dessa forma, é o sistema que vai considerar o que acontece "do outro lado da linha como um comportamento não contemporâneo a 
ele, excluindo, portanto, a possibilidade da "co-presença" (SANTOS, 2009, p. 45).

Compreende-se que a utopia, de certa forma, incentiva o ideal coletivo dotado por um conjunto de pessoas que necessitam sair da teoria para a prática. É o que vemos ser gestado na geração de combatentes que o escritor Pepetela encena no primeiro capítulo de seu romance $A$ geração da utopia:

E de qualquer modo tinham um vasto terreno comum, o ódio à ditadura de Salazar e a esperança na independência das colônias. Opunham-se nos métodos e maneiras de prever a sociedade futura. Uma sociedade onde o Estado ia abolir as classes, segundo Aníbal, uma sociedade sem Estado, pois este tendia a ser o manto sob o qual novas classes se criariam segundo Marta (2000, p. 73).

Pires Laranjeira esclarece que $A$ geração da utopia "é o romance amargurado da distância entre a esperança de uma sociedade e um homem novo e a realidade da guerra, da morte e da miséria" (1995, p. 147). Rita Chaves argumenta que "o ponto de vista narrativo constrói-se com base num processo de relativização que não poupa os chamados 'bons sentimentos' e trabalha o conflito como um elemento positivo mesmo na condução de um projeto coletivo" (2009, p. 126). Em razão disso, Mia Couto justifica que Pepetela precisa desafiar "os fundamentos do próprio pensamento. Ele vai mais longe do que desafiar os limites do politicamente correto. Ele subverte os próprios critérios que definem o que é certo, ele questiona os limites da razão" (2002, p. 63).

A professora Rita Chaves refere-se ainda a outro aspecto importante da cosmovisão do autor angolano: "Pepetela abre-se claramente ao mundo ocidental na referência aos valores gregos, assumindo Angola como um terreno mestiço, onde se cruzam matrizes culturais muito diversas" (2009, p. 131).

Nunca nenhuma é como os sonhos dos sonhadores. [...] É um sonhador [utópico]. - [...] Em Angola será diferente. - Falas como ele. Os iluminados dizem sempre que a sua experiência não descambará como as outras. Não ousam afirmar, porque são ou querem parecer modestos, mas pensam assim: se eu acredito nisto, porquê não se há-de realizar como imagino? (PEPETELA, 2000, p. 113).

Pepetela cria um olhar mergulhado em dúvidas, um olhar que permite menos certezas. Eis a imagem de Angola liberta, erguida pelos interesses modernos. É preciso perceber que há duas formas de explorar a terra e empobrecer o povo assolado pela guerra civil, pela fome e pelas doenças, o povo que a geração da utopia prometeu ajudar. Algumas personagens, como Sara, da $A$ geração da utopia, ajudaram, mas também foram engolidas 
profundamente pelos interesses da classe política interessada em olhar a si própria e manter-se no poder.

A história de Angola após a independência revela que "as propagadas liberdade e justiça para todos são substituídas por clientelismo, pequena corrupção e nepotismo" (MATA, 2009, p. 192). Todavia, antes de a utopia dar espaço a desencantos, os heróis são necessários para acabar com o colonialismo português, como podemos observar no discurso direto feito pela personagem Orlando, namorado de Judite, filha de Sara e Malongo: “[...] Como uma geração faz uma luta gloriosa pela independência e a destrói ela própria? Mas parece que a gente da sua geração não é capaz de a fazer" (PEPETELA, 2000, p. 313).

Dessa forma, compreende-se que os fatos pós-independência são responsáveis por desencantos diversos, bem como pela extensão das condições econômicas e sociais distintas. Também demonstram o falhanço do roteiro a ser cumprido posteriormente por parte dos membros da geração da utopia, mordidos pela serpente do poder, como podemos constatar em passagens como a seguinte: "Um povo tão digno tornado mendigo [...] quisemos fazer desta terra um País em África, afinal apenas fizemos mais um país africano" (idem, p. 305).

Nota-se que essas palavras de desencanto nascem da queda dos heróis da geração da utopia. Nascem, aliás, da "igualdade de boca", ou seja, da permanência da retórica e da corrupção políticas mesmo após a independência, como podemos ver na figura da personagem Vítor/Mundial, na medida em que as suas ações corroboram a sua percepção de que "o homem, sim, é o maior predador de si próprio" (idem, p. 198).

Sobre os heróis de Pepetela, Benjamin Abdala Júnior argumenta que eles

são paradigmas que não se circunscrevem apenas a Angola. Apresentam na verdade modelos de condutas extensíveis à condição humana - um paradigma do homem em geral em sua história e no seu impulso de transformação (2009, p. 173).

Da mesma maneira, Pires Laranjeira afirma o seguinte:

Pepetela atrevia-se assim a questionar a construção de imagens de heróis monolíticos, aplicando à ficção a fecundidade da dúvida sistemática, como quando insinua, através de Sem Medo, que o poder da guerrilha de libertação nacional já transporta em si o ovo da serpente do poder que, após o triunfo, dominará o povo que ajudou a libertar (1995, p. 145). 
Os fatos pós-independência, as guerras civis, o aprofundamento da corrupção, dos preconceitos e dos ódios entre grupos étnicos distintos fazem com que o sonho de uma Angola justa, igualitária e democrática caia por debaixo da terra e, assim, ganhe uma nova forma, isto é, a do movimento para o distópico, como o epílogo da obra esclarece:

Dominus falou, e os assistentes enchiam os sacos com o dinheiro e as poucas jóias e até mesmo as camisas, e os caxicos iam com os sacos despejar atrás do ecrã do cinema e voltavam receber mais, todo o povo dançando e se beijando e se tocando, se massembando mesmo nas filas e nos corredores e depois no largo à frente do Luminar e nas ruas adjacentes, batendo os pés e as palmas e dizendo Dominus falou, a caminho dos mercados e das casas, das praias e dos musseques, em cortejos se multiplicando como no carnaval, do Luminar partindo felizes para ganhar o Mundo e a Esperança.

Epílogo

Como é óbvio, não pode existir epílogo nem ponto final para uma estória que começa por portanto (PEPETELA, 2000, pp. 326-327).

O trecho acima aponta para a conclusão de um ciclo e não para o fim de uma história. Parece haver uma saída da utopia para a distopia, motivo pelo qual se verifica o mergulho da esperança no fundo do mar.

Analisando o "portanto", que abriu e concluiu o romance, ele explode o fechamento e a conclusão de uma geração responsável por iniciar o processo de emancipação política, abrindo assim a porta para transformações sociais - quer para o bem, quer para o mal —, mas que falhou em grandes partes, por exemplo na fidelidade aos seus princípios éticos. Benjamin Abdala Júnior (2009) observa a literatura angolana como uma marca de "ascensão e queda" de utopias, e, assim, como uma literatura caracterizada pelo "desencanto pós-colonial". Mata acrescenta ainda o seguinte:

[...] é essa consciência histórica que leva a que a obra romanesca de Pepetela funciona com uma lógica antiépica que acaba por referenciar os ideais agnósticos da revolução e do espírito nacionalista animado pela imaginação utópica, ideais construídos sobre uma mística do heroico e do épico. São por isso significativos a urdidura da trama e o dispositivo textual da lógica antiépica da novelística de Pepetela (2009, p. 202).

Mia Couto, num dos seus importantes ensaios, intitulado "Que África escreve o escritor africano?", afirma que

[...] passamos por um período em que os nossos heróis acabaram sempre mortos - Eduardo Mondlane, Samora Machel, Carlos Cardoso, Amílcar Cabral - para um outro tempo em que os heróis já nem sequer nascem. [...] O que queremos e 
sonhamos é uma pátria e um continente que já não precisem de heróis (2009, p. $63)$.

A literatura guineense também nasce do contexto colonial com o objetivo de resgatar e afirmar os valores identitários nacionais. Nesse quadro, os intelectuais guineenses começaram a verbalizar as suas reivindicações, por meio da literatura, contra a violência, a exploração e a desumanização. Além disso, a literatura guineense visa quebrar o silêncio em que se vivia ao longo dos anos de colonização. Por isso mesmo é que a produção literária guineense tem trazido novos olhares a respeito da cultura e do pensamento literário sobre povo e país, despertando assim o interesse dos críticos de áreas de conhecimento afins, no sentido de fazer com que olhem para a literatura com olhares de modernidade e sem estranheza.

A partir da luta da libertação nacional, tem-se verificado a emergência dos escritores guineenses. Esse fato tem sido verificado por conta da crescente produção e publicação de obras literárias escritas pelos próprios guineenses com temática intrinsecamente local. Essas produções e publicações têm sido importantes por impulsionar os críticos a se aproximarem cada vez mais da literatura nacional - muito embora, no começo, a atenção da crítica fosse prioritariamente voltada para a valorização das questões sociais, para, só então, passar a concentrar-se nos processos políticos da pós-independência.

O primeiro Liceu Honório Barreto foi criado em 1958, praticamente com um século de diferença do liceu de Cabo-Verde, que teve a sua fundação em 1860. Após a independência, a literatura guineense começou a ganhar outros olhares no campo literário. No final da década de noventa do século $X X$, os próprios guineenses se dedicaram a abordar a cultura do seu povo através da escrita de romances. Nesse cenário, destacam-se Abdulai Silá ${ }^{19}$ e Filinto de Barros.

A escrita desses autores procura denunciar a situação colonial e o momento que o país atravessa depois da colonização - isto é, a situação de fome, de miséria e de exploração do homem pelo homem. Ao mesmo tempo, põem em cena a esperança na liberdade e na justiça ao renderem homenagens aos combatentes da liberdade da pátria. A respeito dessas narrativas, Margarida Calafate Ribeiro e Odete Semedo destacam:

Ao mapearmos a literatura da Guiné-Bissau, é possível antever a trajetória da narração da nação na qual um mito fundador é apresentado por meio duma literatura de combate com as suas manifestações de sofrimento, de renúncia do

\footnotetext{
${ }^{19}$ Abdulai Silá é um dos fundadores da Editora KuSiMon, por meio da qual tem fomentado
} literatura na Guiné-Bissau com publicação de obras de novos(as) autores(as) guineenses. 
colonialismo e de nostalgia de um passado anterior ao tempo da presença colonial (2011, p. 12).

Moema Augel, citada por Marceano Tomas Urem da Costa, evidencia sobre os autores que:

[...] mesmo magoados e descontentes com o sistema colonial, os poetas guineenses dessa época acreditavam numa mudança progressiva na GuinéBissau. Ao se lerem as produções dos poetas guineenses se depara com o testemunho patriótico exaltado por estes poetas (AUGEL apud COSTA, 2018, n.p.).

Assim sendo, o país vai ganhar os dois primeiros romances dos autores nacionais - a saber, Eterna paixão (1994), de Abdulai Silá, e Kikia Matcho (1997), de Filinto de Barros. Abdulai Silá, à época da publicação do romance de Filinto de Barros, já havia iniciado a escrita de $A$ Última tragédia (1995), seu segundo romance publicado. Ele também publicou Mistida em (1997), Orações de Mansata (2007), Dois tiros e uma gargalhada (2013); Memórias Somânticas (2016) e, recentemente, a obra intitulada Kangalutas (2018). Apesar de tudo, Pires Laranjeira considera o escritor cabo-verdiano Fausto Duarte como o primeiro a inaugurar a literatura guineense com o seu romance Auá (1934).

Moema Parente Augel aponta que

[...] os comentários que [o narrador de Barros] exprime [sobre os agouros do Kikia] são, sobretudo, de ceticismo, dando a impressão de que o intelectual de formação marxista e materialista não pudesse aceitar tais fraquezas ou ingenuidades, não disfarçando seu distanciamento (1998, p. 373).

Nesse sentido, a experiência do escritor intelectual no espaço pós-colonial materializa-se conforme ele "tece o cenário cotidiano da vida dos ndjeñerus e dubriadus bissauenses, para usarmos uma expressão crioula para designar a luta penosa pela sobrevivência" (OTINTA, 2011, p. 99). Em síntese, a inserção do enigma do kikia no romance nos dá a pista para compreender o que o autor, em seu tempo, não foi capaz de desvendar.

Filinto de Barros procura, com a linguagem literária, questionar as relações econômicas, sociais, políticas e culturais da classe dominante bissauense. $O$ autor, em inteligente intervenção, interroga-se acerca dessa questão através da personagem Benaf, que lhe serviu de intelectual questionador e crítico dentro da narrativa. Diz ele:

Como explicar que dum grande "combatente" tenha surgido um miserável? As histórias do Papai são para ter crédito? [interroga-se o narrador-escritor] [...] uma 
coisa era certa, N'Dingui lutou, comandou, detém medalhas de combatente da liberdade da pátria, e está ali seco que nem um carapau. Mas seco em tudo, até na audiência que lhe serve de velório (1999, p. 21).

Essa passagem dá indícios de como o Benaf procurará de toda maneira compreender o complexo da epopeia, mesmo não compartilhando o mesmo ponto de vista do velho Papai. Ou seja, ele queria compreender por que os excombatentes vivem esquecidos e em miséria na cidade de Bissau. Nessa mesma linha do pensamento, questionou o ex-combatente Baifaz: "não consigo compreender o que fizemos de tão mau e de tão diferente de Cabral, para estarmos a correr todos estes perigos!" (idem, p. 134).

Se o Benaf tivesse tido contatos com a Mana Tchambú, que conhece bem os seus clientes, homens da Luta, e teria chegado a conclusões diferentes. Teria concluído, como o seu tio N’Dingui e o velho Papai, que eram do partido; e as acompanhantes desses camaradas que os deixaram sem alternativas na vida. Também teria percebido o porquê dos clientes da Tia Burim Mudjo estarem desiludidos, já que o dinheiro não era um elemento importante para os clientes da Tia Mana.

No olhar do escritor, a desgovernança continua de certo modo a dificultar a consolidação e o desenvolvimento do Estado guineense, de modo também a provocar a antagônica aceitação desse estado de coisas. Mas, nas palavras de Filinto de Barros, é preciso "enxergar mais longe e descobrir os beneficiários últimos das ações criminosas” (idem, p. 138). É por isso que N’Dingui morto, transformado em kassissa, foi escolhido pelos seus companheiros da luta e pelo seu chefe Cabral para convencer os que estão vivos na sua terra "a se corrigirem e mudarem para combater toda a praga que se abateu sobre a pátria e sobre os ideais da luta" (OTINTA, 2011, p. 102). Ou seja, é preciso encontrar os verdadeiros autores das más ações e puni-los, pois tudo indica que a revolução tinha sido "autodestruída por completo" e "teimava em afastar-se do caminho traçado" (idem, p.140). É preciso que os "combatentes escutem certas verdades" (idem, p. 142); entretanto são verdades que dizem respeito aos fatos que estão à beira do intolerável - os casos de corrupção, clientelismo e decepção que, a cada dia, geravam repugnância na população quanto ao processo revolucionário "pró-independência".

O escritor Filinto de Barros, ao descrever, no campo ficcional, a estratégia de sobrevivência dos heróis da independência, parece querer evidenciar que eles fecharam os olhos para não assistirem as metamorfoses da luta, processo cujo resultado destrói tudo e todos, em permanente "sessão de assassinato". 
Assim como na "destruição das estátuas", o objetivo parece ser o de esquecer tudo. Enfim, para salvar-se da frustração (BARROS, 1999, pp. 100-106).

A percepção de uma coincidência entre os romances de Pepetela e de Filinto de Barros, numa perspectiva de cruzamento temporal, baseia-se em duas razões: o projeto revolucionário do movimento libertário e suas utopias, de um lado, e a conscientização acerca do devir social presente nas recentes histórias de Angola e da Guiné-Bissau, de outro. Os dois escritores assumiram a responsabilidade de produzir história encenando ações transformadoras do sistema colonial para o sistema da pós-independência.

\title{
4.1
}

\section{Uma nação criada e um sonho perdido: os heróis esquecidos sob os escombros}

\author{
Esse romance não é uma resposta a \\ nada. Apenas uma estória sobre uma \\ geração que fez a independência de \\ Angola e não soube fazer mais.
}

Pepetela

Neste subcapítulo, procuramos fazer a análise dos romances $A$ geração da utopia e Kikia Matcho. Buscamos elaborar uma compreensão da crítica ao abandono dos ex-guerrilheiros nos primeiros passos da construção dos estadonações em que essas obras foram produzidas. Do mesmo modo, buscaremos refletir sobre as relações entre literatura e sociedade de modo a compreender como se projeta a escrita literária na construção da história.

Os romances Kikia matcho e $A$ geração da utopia nos oferecem imagens muito expressivas do contexto posterior às guerras de libertação nacional em Angola e Guiné-Bissau, encerradas em 1974. A passagem de um período utópico para distópico também foi vivida pelas personagens de ambos os romances. Aníbal (o sábio) e Papai oferecem algumas pistas valiosas para entender a crítica dos autores a respeito da desistência daqueles que lutaram e que deram as suas vidas para que as nações se tornassem livres e independentes.

Em quatros décadas de independência, gerações de escritores africanos testemunharam, puseram em cena e deram visibilidade aos processos envolvidos no nascimento das suas nações. Atentos aos impasses sóciohistóricos fizeram ressoar a palavra literária como instrumento da resistência 
para as velhas e novas formas de opressão, sendo o romance o espaço de expressão preferencial.

Após a independência, houve uma sensível desestruturação política em Angola e Guiné-Bissau. É preciso considerar a hipótese de que, além do final das guerras pela autodeterminação, em 1974, a queda do muro de Berlim em 1989 e a dissolução da União Soviética contribuíram, numa perspectiva geopolítica, para este processo de desestruturação interna. Diante da mudança verificada na correlação de forças políticas mundiais e da ascensão compulsória das políticas ocidentais, as utopias da revolução parecem ter-se apagado. As expectativas criadas pelos antigos Combatentes da Liberdade da Pátria convertem-se em decadência, crise e instabilidade política no interior dos seus respectivos países. Assim, nas manifestações do esquecimento em $A$ geração da utopia e Kikia Matcho os guerrilheiros são testemunhas de um mundo violento. Eles passaram pelas mesmas situações de distopia, de decepção e de abandono social. Se a independência foi uma utopia, o pós-independência parece ter-se delineado como uma ameaça.

Esta passagem ilustra como Aníbal, guerrilheiro utópico, passa a ser uma personagem distópica - ou seja, desencantada. Na cena construída por Pepetela, parece que o personagem desistiu da luta, ou que terá de enfrentá-la de outra maneira, segundo a professora Rita Chaves:

\begin{abstract}
Afastado da capital e de qualquer centro de decisão, fica transferido o palco onde se vai dar um grande combate, o combate de um homem disposto a preservar-se inteiro com seus próprios monstros, com seus medos e seus limites. Inteiro, mas isolado, imponente para lutar contra outras feras, Aníbal compõe a imagem do espírito das chanas do Leste, miticamente identificado com o sonho que o conduziu à luta pela independência. A ilusão a essa força no fim do capítulo exprime a hipótese de que, adormecida, a utopia pode um dia acordar (2005, p. 102).
\end{abstract}

A história de cada guerrilheiro é a possibilidade única de acesso à utopia sonhada e anunciada. Ao colocarem o leitor em contato com as vidas desses guerrilheiros e com os seus impasses, os narradores recuperam o passado e inscrevem, no presente, questões recalcadas ou esquecidas. Por isso, contar a história de um ex-combatente morto e de outros abandonados, desiludidos e desesperançados com o projeto da construção do estado-nação significa refletir sobre passado, presente e futuro simultaneamente. Como afirma o escritor José Luandino Vieira, "é que as lições da vida têm de ser sempre passadas a limpo, só nossa morte é quem pode ficar em rascunho" (2009, p. 94). 
É preciso salientar que os romances Kikia Matcho e A geração da utopia também projetam visões de futuro. Ao focalizarem os dilemas dos últimos anos do século XX, Pepetela e Filinto de Barros abordam a realidade social angolana e guineense a partir de um ponto de observação bastante crítico. Por isso, muitas vezes, o comportamento das suas personagens não permite uma compreensão fácil.

De acordo com Alexandre Montaury, a produção literária nas variantes africanas da língua portuguesa, a partir dos anos de 1940,

[...] pôs em cena uma sistemática interrogação dos processos de assimilação cultural, de punições violentas, de imposições coloniais, aprofundando uma sensibilidade anticolonial que foi radicalizada nas décadas posteriores. Neste aspecto, é inevitável referir aos escritores angolanos que, como intelectuais, operaram no campo ficcional uma estratégia de barragem às práticas e às linguagens do comum, tal como eram definidas segundo a agenda do colonialismo português $(2020$, p. 53).

Em entrevista concedida ao jornal Estado de São Paulo, em 2000, Pepetela demonstra a sua preocupação e a sua insatisfação diante de um projeto político que, de acordo com ele, não se concretizou. As novas políticas adotadas pelo governo angolano após a independência não trouxeram a liberdade e a igualdade social, utopia tão almejada pelos ex-guerrilheiros antes da independência. Dessa forma, a narrativa crítica do intelectual expõe o quanto "os impasses, as decepções e hesitações permaneceram mesmo após a vitória contra o colono, deixando claros os limites do novo regime, que não extinguiu as heranças coloniais" (CHAVES apud MACHADO, 2016, p. 2).

Nesse sentido, podemos afirmar que os dois romances em questão partilham tanto a face pós-moderna quanto a face pós-colonial do período posterior às independências. Assim, é na prática literária que se torna possível destruir "mitos e dissemina[r] dúvidas e incertezas, sem fugir, contudo, à crítica e à revisão históricas necessárias" (SALGADO, 2003, 129).

É justamente nesse contexto de uma literatura da pós-independência que os dois escritores, Pepetela e Filinto de Barros, atuam como intelectuais engajados que visam afirmar a diferença e reivindicar a pátria tal como era a proposta/utopia dos intelectuais revolucionários. Este ponto de vista incômodo confirma a capacidade intelectual e social dos escritores para os cenários políticos e culturais angolano e guineense.

A distopia de Angola parece estar concentrada no capítulo intitulado "O Templo", do romance de Pepetela, quando uma das personagens percebeu a presença da corrupção na sociedade angolana. Afirma o narrador: "E é triste 
sentir que a nossa geração, que vos deu apesar de tudo a independência, logo a seguir vos tirou a capacidade de a gozar" (PEPETELA, 2000, p. 314). Na mesma linha, essa distopia também é caracterizada pelos casos da corrupção dos governantes - casos que têm relação com as cobranças de impostos altos, com as disputas pelas terras ricas, com as indústrias do petróleo, diamante e madeira e, por fim, com os desvios dos bens comuns. Segundo aponta Maria Fernanda Afonso,

Com efeito, passadas as celebrações das independências, a realidade social surge desarticulada e o mundo oscila, para os africanos, com a tomada de consciência fulgurante das suas dificuldades. Cada enunciado narrativo torna-se África o espelho de um número infinito de situações marcadas por um por um clima de angustia e de perda (2004, p. 391).

O capítulo "O Templo" apresenta, assim, governantes corruptos que roubam o dinheiro público para ostentar riqueza com mulheres nas ruas. Para muitos, o único caminho para a salvação desse cenário político é a religião, destaca a personagem Elias numa das conversas com o político Vítor Ramos:

[...] Daqui transbordará para África e depois para todas as diásporas africanas. Imagina o mercado mundial de almas à nossa disposição. Com as crises econômicas, com a perda da utopia da libertação política, com o fim do inimigo que estava do outro lado na guerra fria, com a dívida externa que tira qualquer hipótese de desenvolvimento aos nossos países, os jovens desempregados e sem instrução, a delinquência e insegurança galopantes, tudo isso leva as pessoas a verem a religião como a única salvação (PEPETELA, 2000, p. 450).

Em cada capítulo, percebemos como o escritor busca questionar a perplexidade instalada no país. Os primeiros passos dados em Angola após a guerra colonial revelam "o fôlego eufórico, utópico, dos guerrilheiros por uma identidade nacional liberta de todas as opressões, corrupções e desigualdades sociais que, supostamente, acabariam com a saída do colonizador" (JUNIOR, 2017, pp. 10-11). Porém, no trecho destacado a seguir, está muito claro como os interesses da nação vão sendo deixados de lado em detrimento de interesses particulares dos políticos. Sendo assim, podemos perceber que os ideais da luta por uma coletividade já não fazem sentido para muitos que sonharam com ela:

Maldita guerra! Os que a iniciaram abandonaram-na, os outros que se arranjem... Caramba, estou a dizer o mesmo que o povo. Mas é verdade, merda. Ninguém o tinha obrigado, se nela participava era por vontade. Deixa lá disso, sei bem como é isto de ser voluntário: uma pessoa é obrigada, o que dirão os amigos, o que será o futuro? Voluntariado forçado! A esta obrigação chamamos consciência política, nome bonito para nos enganarmos (PEPETELA, 2000, p. 161). 
Ainda acrescenta o narrador: "Não, nada já tinha importância. O passado fora enterrado na areia da chana e mesmo as promessas e os ideais colectivos" (idem, p. 192). Dessa forma, os jovens políticos idealistas que assumiram a liderança após a independência em Angola não podem ser considerados mais os mesmos, pois os ideais políticos se perderam e tudo se "adulterou". A Angola pela qual a "geração da utopia" lutou acabou por fraturar-se ao meio, cedendo o lugar à dura experiência da guerra. A nação idealizada pelos revolucionários, no momento da narrativa, já não mais existe, conforme descreve o narrador:

[...] Não temos futuro, nem representamos o futuro. Já somos o passado. A nossa geração consumiu-se. Fez o que tinha a fazer a dado momento, lutou, ganhou a independência. Depois consumiu-se. E preciso saber retirar, quando não se tem mais nada para dar. Muitos não sabem, agarram-se ao passado mais ou menos glorioso, são fósseis. (idem, pp. 220-221)

A produção literária contemporânea guineense, nas suas diferentes variedades, também reflete as preocupações das elites urbanas, inconformadas com a situação política e social que o país atravessa desde a independência até os dias atuais. Nota-se que as obras ficcionais que se produzem na GuinéBissau desde a independência até hoje continuam a desempenhar um papel fundamental no horizonte utópico e continuam atuando como porta-vozes dessa consciência "de identidade coletiva, evidenciando, portanto, a importância da literatura para a formação nacional" (VALANDRO, 2010, p. 23).

Kikia Matcho é um romance composto por cento e sessenta e três páginas, as quais são divididas em treze capítulos de diferentes extensões, sem títulos. Ele é acompanhado por um glossário de cento e vinte termos ou expressões do crioulo, pois é uma obra escrita em português que traz elementos da língua crioula da Guiné-Bissau.

O romance, que revela diferentes experiências vivenciadas pelos exguerrilheiros, também apresenta críticas a respeito da corrupção e da instabilidade política (explicitada pelos sucessivos golpes de estado) que marca o período. Um exemplo disso é a personagem Papai. É em torno dele que se dão essas problemáticas. As decepções ocorrem ao longo do romance, durante os preparativos para a realização da cerimônia fúnebre do ex-combatente N’dingui Có. Quando o personagem Benaf mostrou desinteresse e desprezo pelas histórias heroicas do ex-combatente, o personagem Papai lhe conta sobre a luta de libertação. O narrador descreve o comportamento de Benaf: 
Será que N'dingui levou consigo este mesmo alimento? Será que o tio concluiu, após anos de solidão, de miséria, que valeu a pena ter participado na Luta? Será que N'dingui também compartilhou desta mística que foi a epopeia da Luta, mesmo sabendo que a única herança era este fato de madeira que nem foi feito à sua medida? (BARROS, 1999, p. 16).

Cabe destacar que o sonho da independência não durou muito tempo. E na instituição do Estado só reina a incompetência porque "os novos chefes eram treinados nos centros especializados de propaganda para lidar com a nova realidade" (idem, p. 20). Esses motivos contribuíram para o não desenvolvimento do país, conforme constatamos ao longo da nossa análise: "em vez de livros, medicamentos, surgiram os volvos e a comadres ${ }^{20}$ e, como corolário, a violência policial" (ibidem).

\title{
4. 2
}

\section{As contradições entre a tradição e a modernidade: uma análise das personagens Benaf, Joana e Papai.}

\begin{abstract}
Estamos todos nós estreando um combate interno, para domesticar os nossos antigos fantasmas.

Mia Couto

[...] apesar de todo o progresso feito nos últimos anos, parece que ainda continuam a pairar entre nós alguns fantasmas do passado.
\end{abstract}

Abdulai Sila

De acordo com Stuart Hall, as identidades formadas dentro do contexto colonial são construídas com objetivo de recusar ou rejeitar o engajamento das histórias "locais ou de seus desdobramentos culturais" (2011, p. 41). Um dos campos em que se faz sentir essa disputa é o da tradição, isso porque nela, na tradição, há significações/interpretações que precisam ser postas à margem para que possa prevalecer uma única versão que conduza à política dominante, geralmente tutelada por uma classe dominante. Desse modo, outras matrizes da tradição acabam sendo esquecidas: "a tradição é um elemento vital da cultura, mas ela tem pouco a ver com a mera persistência das velhas formas. Está muito mais relacionada às formas de associação e articulação dos elementos" (idem, p. 243). Diante desta consideração do teórico jamaicano, entendemos que o romance de Filinto de Barros apresenta três grandes questões: (1) a tradição

\footnotetext{
${ }^{20}$ Comadre, em crioulo guineense, significa amante ou concubina.
} 
cultural africana guineense; (2) a preocupação da ruptura com essa tradição; e (3) a reinvenção da cultura tradicional guineense como um modo híbrido de se relacionar com os novos desafios que o mundo contemporâneo impõe.

Boa parte das contradições encontradas nos livros dos autores que ora estudamos tem a ver com as práticas coloniais presentes no seio da sociedade, como cultura viva, mesmo em tempos de autodeterminação. A longa duração do colonialismo português na África produziu uma espécie de uma tradição colonial interna, o que seria uma contradição incontornável. Os jovens do romance do Filinto de Barros, que buscam emigrar para se tornarem consumidores de produtos mais caros e melhores, ou para buscar melhores empregos, não estão propriamente interessados na identidade nacional. Eles parecem querer se inserir na ordem econômica de consumo da modernidade. Isto seria uma contradição; ou seja, uma tradição formada contra a independência e a favor das premissas coloniais.

No romance Kikia Matcho, Filinto de Barros constrói a personagem de António Benaf, que, com a morte do seu tio, o ex-combatente N'dingui Có, representa os intelectuais da nova geração junto à velha geração (Papai, Infali Sisse e Tia Mana) em busca de uma solução para o desenvolvimento da GuinéBissau. A realização da cerimônia de funeral, a qual os comandantes não se dignaram a presenciar, representa um encontro que deveria permitir que as diferentes classes tivessem oportunidade de apresentar opiniões relativas à situação da nação. "Mas falhou devido à ausência de comandantes" (BARROS, 1999, p. 114).

Filinto de Barros começa o desenho do seu romance num plano do ritual mítico cultural, por meio de um comunicado que permite ao sobrinho de N'dingui, António Benaf, tomar conhecimento do falecimento do seu tio: "sabes, com o desaparecimento do correio e praticamente sem telefone com o interior, Rekado Ku nô Ten pa Konta ${ }^{21}$ transformou-se no único meio de comunicar com algum familiar ou amigo no resto do país" (idem, p. 5).

Existe um contraste enorme entre o mundo tradicional africano e o mundo moderno colonial, progressivamente inoculado nas culturas da população depois de tantos anos de presença colonial. Benaf teve enormes dificuldades em entender a cerimônia fúnebre do seu tio porque, para ele, segundo nos relata o narrador, "o desenvolvimento significava nada mais, nada menos do que cortar

\footnotetext{
${ }^{21}$ De acordo com Jorge Otinta, Rekado Ku nô Ten pa conta, ou seja, notícias a veicular, significa "apresentações de notícias variadas que vão desde os comunicados de falecimento e de missas de sétimo dia até à cerimônias realizadas nos irans e nas balobas; além de comunicar-se com parentes longínquos sobre reuniões familiares e outras necessidades afins" (2011, p. 247).
} 
duma vez por todas com o mundo do velho e as suas amarras sociais" (idem, $\mathrm{p}$. 145), em que a não realização da cerimônia ou do ritual de passagem do seu tio "deste mundo" para o "outro" poderia lhe transformar num kassissa (espírito maligno).

Benaf mal sabe da morte do tio N'dingui Có e já recebe imediatas condolências dos seus colegas, o que demonstra certa práxis tradicional. Ao mesmo tempo, seus colegas o alertam para que tenha cuidado com o que iria gastar durante a cerimônia fúnebre do seu tio em Guiné-Bissau, já que ele seria o mais indicado para se colocar à frente de todo o processo de realização da cerimônia, na condição de familiar próximo do malogrado, conforme nos aponta o narrador: "parece que o nosso djumbai terminou! Penso que durante estes dias vais estar ocupado com as cerimônias de tchoro, dado que junto dos papéis isso é muito forte. Coragem e sobretudo muita força e muito cuidado com o teu bolso! Adeus!" (idem, p. 10).

A mesclagem na Guiné-Bissau fez com que houvesse confrontos de rituais cerimoniais e é justamente o que se verifica durante o procedimento da cerimônia do funeral do ex-combatente N'dingui Có. De acordo com Fernando Nhaga Cumba, trata-se de um "ritual tradicional de sacrificar um porco porque o seu sangue serviria de sinal de libertação da alma e para fazê-la subir a Deus (para animistas)" (2017, p. 54). O ritual implica a "presença de um padre que deve benzer o corpo como sinal de aliança com Deus (para os cristãos)" (BARROS, 1999, p. 113). Muito embora nesse contexto o padre muitas vezes esteja ciente de que sua presença é irrelevante, "seria erro recusar a bênção a esta gente"; portanto, "estava a cumprir a sua missão no continente" (ibidem).

Essa forma de hibridismo cultural na Guiné-Bissau também é referida por Barros quando, no romance, se encena a cerimônia do funeral de $N^{\prime}$ dingui:

\footnotetext{
O que dizer dessa mistura rocambolesca do padre [religião católica] e do porco sobre o qual o caixão deve passar [ritual tradicional]? Benaf perdeu a mística do Continente. Assim não poderia compreender o híbrido que resultou da civilização cristã, tão cara aos europeus! O paganismo e o cristianismo juntaram-se não só para se tolerarem, mas para se complementarem! É assim a África, o continente da vida, o continente que em vez de repudiar as influências externas acaba por as assimilar, transformá-las e fazer delas traços culturais à sua maneira. Era isto que Benaf não compreendia e que jamais virá a entender! (ibidem).
}

Por representarem a velha geração, os anciões fizeram com que Benaf fosse eleito pela alma do seu tio N'dingui para estar à frente da realização da cerimônia e "para acalmar a família [o povo]" (idem, p. 145). Como diz o narrador, "(...) o velhote era a única pessoa capaz de levar o processo para 
frente" (ibidem). Nota-se, porém, que devido à longa presença histórica de cultura europeia, "a África tinha-se esfumado no seu ser" (idem, p. 17), isso porque as novas gerações talvez tenham se desenraizado da essência da cultura tradicional africana. Benaf "voltou [ao seu país de origem] porque era africano e intelectual, portanto podia ser ministro ou presidente, mas do continente não conseguia reter nem compreender a profundidade da sua mística" (ibidem). Por ter sido formado na Bulgária, sofreu um processo de assimilação cultural européia - por essa causa, ao longo do processo da cerimônia de funeral do seu tio, ele entrou em contradição em várias ocasiões com os seus familiares, sobretudo com o ex-combatente Papai e com a sua prima.

Benaf mal regressa ao país e já encara a enorme tarefa de conduzir o processo do cerimonial fúnebre do seu tio, N’dingui Có. Relativamente a esse processo, Benaf tinha várias funções a desempenhar. Entre elas, destacam-se "a permanência no local desde a noite do velório até ao baixar do caixão"; a realização da cerimônia de "lavar sangue derramado pelo N'dingui na Luta" (idem, p. 20); e a realização da cerimônia de "toca-choro na terra natal do seu tio, Safim" (idem, p. 111). Todo o processo, durante a longa noite de velório, permitiu-lhe refletir profundamente sobre a posição a tomar relativamente à vida. Também lhe serviu para a elaboração de novas ideias acerca do comportamento de governantes e acerca da Nação de modo geral.

Seguindo as pistas do narrador, "o velho [o ex-combatente morto N'dingui Có] era até interessante, simpático, mas os temas da sua tradição local eram sempre os mesmos a fazer lembrar o outro lado da consciência, precisamente o lado que [Benaf] estava interessado em eliminar" (idem, p. 145). É precisamente isto que queremos realçar: esta contradição entre o mundo tradicional africano e o mundo moderno. O personagem Benaf encontra dificuldades em realizar a cerimônia do seu tio porque, para ele, conforme nos aponta o narrador, "o desenvolvimento significava nada mais nada menos do que cortar duma vez por todas com o mundo do velho e as suas amarras morais" (ibidem). A modernidade a que estamos referindo-nos aqui não é apenas a do poder público oficial, e sim a do poder tradicional, sistema que o personagem intelectual, Benaf, tentava eliminar, pois era uma maçada - e que maçada!

Em Kikia matcho, Filinto de Barros apresenta-nos o Benaf na figura do intelectual que vive o dilema entre tradição e modernidade, motivo pelo qual ele não conseguiu admitir certas práticas tradicionais na cerimônia do funeral do seu tio. A passagem a seguir ilustra essa recusa do Benaf. Diz ele: 
Olhem só para estes papéis! Vocês são mesmo aldrabões! Se calhar inventaram isso só para terem mais carne de porco e cana para beberem! Vocês são atrasados deste país. Não trabalham, ou antes, agarram no vosso dinheiro e metem-no em cerimónias e mais cerimónias que nunca mais acabam, em vez de arranjarem boas casas, vestirem bem e pensarem numa vida melhor para os vossos filhos (idem, p. 132).

Em relação à modernidade, Kikia Matcho será diferente, pois apresenta mais certezas dos fatos do que dúvidas. Isto é: encena, de forma geral, uma realidade social que resiste a todas as épocas, que perpassa todas as ideologias, inclusive o que hoje é chamado "radical". Nesse contexto, Benaf aparece como questionador-crítico da realidade cultural guineense, mas também a sua figura representa "dos que têm um pê na tradição local e outro na modernidade" (2011, p. 244), conforme salienta Otinta. Já Papai é um personagem que nunca está satisfeito com a situação pós-independência, pois questiona essa realidade constantemente, mesmo quando dá uma lição ao Benaf.

A morte de N'dingui, para o próprio sobrinho Benaf, não parecia ter tanta importância. Em vida, não via ninguém a dar-se por interessado no velho tio. Agora morto, todas as atenções se voltam para um cadáver a princípio insignificante. O que ele não consegue admitir é que ali, na Guiné-Bissau, assim como em tantas outras partes da África, os gestos juntamente com as intenções sejam o elo que perpetua e renova os laços de solidariedade entre as famílias; elo que ao mesmo tempo renova as alianças entre os vivos (deste mundo) e os mortos (que estão no além).

Considerando a perspectiva cultural do povo guineense, na base do romance, nota-se que tudo gira à volta da realização da cerimônia de funeral do protagonista N'dingui. Na Guiné-Bissau, como se sabe, os grupos étnicos acreditam num deus supremo (invisível e inacessível) que deseja o bem para os vivos da terra. Entretanto, esse ser, enquanto entidade invisível e inacessível, possui forças intermediárias espirituais, quer dizer, o Irã: "um espírito ancestral ou qualquer outro ser sobrenatural" (1998, p. 5), conforme descreve Jong. Geralmente os seus crentes solicitam-nos por intermediários conhecidos como Balobeiros ou Djambakus; isto é, videntes ou anciões da tabanca (aldeia). Benaf representa o grupo de jovens que, após a independência, e devido à possibilidade familiar — ou que, inversamente, por falta de apoio familiar —, teve que recorrer aos estudos no estrangeiro.

No contexto atual, alguns desses jovens estão de regresso ao país. Eles representam os grupos de intelectuais da nova geração com altos graus 
acadêmicos. Uns possuem Licenciatura, Mestrado e Doutorado, outros encontram-se no sistema político do país, enquanto alguns outros não conseguem emprego com facilidade. Segundo Cumba, na Guiné-Bissau

raramente se fazem concursos públicos para recrutar novos quadros de funcionários, nem se leva a cabo o processo de reforma dos que se encontram nos serviços públicos desde a independência, mesmo com a velhice estes continuam no sistema. [...] o enquadramento de novos funcionários em alguns ministérios ou instituições públicas geralmente faz-se por nepotismo, sendo necessário que se identifiquem com raízes partidárias ou apoio familiar (2017, p. 75).

As práticas citadas levam à alienação de vagas do sistema público guineense que deveriam ser ocupadas por quadros com preparação científica. Muitos optam pela emigração, como é o caso da personagem Joana, enfermeira desde o período colonial, que representa os funcionários que perderam os seus empregos após a formação do novo estado-nação. É evidente que os rituais tradicionais guineenses não faltam entre os que se encontram na diáspora, como é o caso de Joana e de companheiros residentes em Portugal, "como sinal de defesa pelo perigo da não autenticidade" (BARROS, 1999, p. 79).

De acordo com o narrador, o diálogo entre Joana e seu tio camarada N'dingui Có "aconteceu no ano de 1997. Joana costumava recordar-se da conversa com o tio" (idem, p. 20). Ao longo dessa conversa, o ex-combatente the pediu para não migrar para Portugal, Lisboa; Joana, por sua vez, recusou o pedido e deixou a capital guineense rumo a Portugal porque acreditava que lá em Lisboa teria mais oportunidade de emprego: "a Joana quis ajudar, mas o poder político não permitiria" (ibidem). Ela jamais poderia compreender que o novo poder estivesse amarrado nas suas próprias contradições, sem poder conciliar a realidade da luta com a nova realidade dum país carente de recursos humanos capazes.

$\mathrm{Na}$ capital da antiga metrópole, Joana acaba por perceber que a sociedade portuguesa não se importava com as diferenças culturais, sobretudo entre mestiços e negros, guineenses e cabo-verdianos. Conforme expressa o narrador,

[...] Na realidade, a dura existência ensinou-lhe que a cor da pele conta pouco num mundo de desigualdade baseado no poder de compra. Burmedjos, pretos, Guineenses, Cabo-verdianos, estavam todos aí, juntos frente ao mundo ocidental, à mercê dos mais ricos (idem, p. 37). 
Joana acaba por entender que, para os portugueses, todos os africanos são negros e pobres, que não há diferenças entre eles e que, portanto, todos merecem ser tratados da mesma forma. Por isso, ela precisava aceitar condições de vida que, provavelmente, não aceitaria em Guiné-Bissau.

Também se observa que a Joana não se deixou assimilar, do ponto de vista cultural, durante a sua estadia em Lisboa - ou seja, não perdeu a tradição guineense em Portugal. Ela fez de tudo para manter as tradições herdadas e, por isso, reservou alguns traços delas. Um exemplo disso foi quando ela juntou os amigos de Lisboa para Ihes servir café, aguardente, dar missa de oito dias com bolos, cuscuz e fidjós ${ }^{22}$, conforme afirma o narrador:

No entanto, iria receber os seus amigos, servir-lhes café, aguardente, dar missa de oito dias com bolos, cuscuz, fidjós, tudo para manter a tradição. Era uma das formas mais originais que a comunidade tinha encontrado para se defender da aculturação que a Europa exerce nos emigrantes (idem, p. 35).

A Joana sempre procurou se defender da aculturação exercida pelo continente europeu sobre a comunidade dos imigrantes guineenses em Lisboa. Por isso, ao longo da narrativa ela procura educar o seu filho segundo usos e costumes tradicionais da Guiné-Bissau.

Também lancemos o nosso olhar para o personagem Pedro, filho da Joana em Lisboa. Devido a sua imaturidade, queria ser "branco" a todo o custo para não ser chamado pelos colegas da escola de "pretinho de Guiné que lava a cara com café e vai à missa de lopé". A mãe, em resposta ao filho que está numa situação de resistência, o aconselha: "não deves tomar parte nas brincadeiras onde a tua raça é insultada" (idem, p. 28).

Portanto, é possível afirmar que ela representa o perfil sociocultural dos emigrantes guineenses que se espalharam em diásporas à procura de melhores condições de vida. Além disso, a personagem condensa alguns significados culturais que apontam para a figura dos emigrantes acadêmicos com alto grau de formação que preferem passar por dificuldades no estrangeiro a regressar para o seu país de origem, uma vez que há constante instabilidade política provocada pelos governantes. Jorge Otinta, em sua análise, constata que:

As trajetórias pessoais das personagens do romance de Filinto de Barros são contadas no romance em retrospecto, de forma que o leitor que não viveu a história dos tempos do Ajustamento consiga entender como o submundo dos irãs amedrontava a sobrinha do malogrado N'Dingui nas paradas de Lisboa, seu canto de exilada, de desterrada e imigrante (2011, p. 237).

\footnotetext{
${ }^{22}$ Fidjós é um prato típico preparado com fritura.
} 
Depois de Joana ter passado pela Djambakus ${ }^{23}$ do Laranjeiro, que a indicou uma médium, ela acaba se encontrando com uma conhecida que parecia ser tudo menos uma médium. Esse fato nos leva a questionar: por que a imagem do kikia com o rosto do tio ainda continua a perseguindo? Quiçá o narrador quer mostrar ao leitor que naqueles tempos de Campu Quent ${ }^{24}$ a situação era difícil; ou seja, a situação de vida de todos os guineenses estava pesarosa tanto em Bissau como em Lisboa.

É muito relevante destacar também que Joana, depois de muitos anos de estada na Europa, fechada no ghetto cultural que the serviu como defesa espontânea contra o ostracismo, não conseguiu perceber as mudanças que estavam a ocorrer no seu país natal, a Guiné-Bissau. A personagem enfermeira continuava a visionar o país que deixara sem tomar conhecimento de que lá, como na Europa, "as forças da antinatureza estavam em marcha na sua inglória luta de tudo destruir em nome do desenvolvimento" (BARROS, 1999, p. 146).

No romance $A$ geração da utopia e nas sociedades angolanas, os homens com ideais, como Aníbal e o Sábio, parecem conviver dialeticamente com o desencanto e a traição do sonho nacionalista:

\begin{abstract}
Depois de tu saíres de Portugal, a Marta disse-me que tu só tinhas dois caminhos, ou morrer na guerra, o que seria o melhor para ti, diz Sara a Aníbal, ou desencantares-te. Adivinhou. Porque perseguias um sonho utópico de revolução. Afinal desiludiste-te mesmo (PEPETELA, 2000, p. 207).
\end{abstract}

O mesmo acontece com os personagens Joana e Benaf, do romance Kikia Matcho, quando se defrontam com o problema do desemprego em Lisboa e na Guiné-Bissau. Joana contina a alimentar a esperança de que a sociedade portuguesa não the empregou, mas que, pelo menos, Ihe garantirá uma condição, ao passo que Benaf mantém o sonho de deixar a sua esposa e o seu filho em Sófia (Bulgária) para vir a se tornar "ministro" na Guiné Bissau e, ao mesmo tempo, enriquecer. São projetos que parecem se distanciar cada vez mais.

Refletindo sobre as peripécias de Joana em Lisboa e de Benaf e Papai em Bissau, podemos encontrar a resposta para o enigma da coruja com o rosto do defunto N'dingui. Neste caso, trata-se de buscar respostas para descortinar os mistérios do ser humano. De outra forma, a coruja também parece remeter para o que nos parece ser o fio condutor deste trabalho: o esquecimento (desvio) e a

\footnotetext{
${ }^{23}$ Djambakus significa curandeiro ou adivinho.

${ }^{24}$ O termo Campu Quenti expressa que a situação da Guiné-Bissau está difícil para toda a população.
} 
lembrança (a busca) de princípios norteadores e fundadores da nação guineense.

No entanto, Filinto de Barros parece nos convidar a refletir sobre a morte da história da independência e da pós-independência. Também ele nos alerta para a necessidade e a urgência de escrever e descrever fatos históricos e sensibilidades ativadas para as gerações vindouras, de modo a evitar que a história morra aos poucos - afinal, como o próprio narrador constata, quando não se atenta a essa necessidade e a essa urgência "a nossa história vai morrendo" (BARROS, 1999, p 110.). Urge, portanto, reagir. Ao mesmo tempo, ele tece uma triste constatação: "como se já não estivesse morta" (idem, p. 105). Isso demonstra a insatisfação dos veteranos diante da traição de sentimentos patrióticos da história que são postos em xeque no desenvolvimento do romance.

Focalizando heróis que são "entregues ao alcoolismo e à frustração" esse é o desalento do combatente, expressão que serve como subtítulo do romance -, Filinto de Barros resgata, em Kikia Matcho, por meio do silêncio, as suas histórias e as suas queixas. Barros aponta a distância que separa os excombatentes dos atuais dirigentes da nação, bem como os rumos tomados para conduzir o país e os motivos que geraram tanta modificação do poder.

Defendemos, aqui, a hipótese de que se revela, em Kikia Matcho, um choque geracional ocorrido entre os mais jovens e os mais velhos diante da situação econômica da Guiné-Bissau no período da pós-independência. Em nossa leitura, o autor procura evidenciar a forma com que cada jovem lida com o fato de retornar a Bissau diante do quadro de instabilidade política e de golpes de Estado. O quadro os incentiva a deixarem o país, mas, não obstante os sucessivos problemas guineenses, tais como infraestrutura falha e governo(s) igualmente falho(s), o autor registra e reconstitui, no campo da ficção, a incrível capacidade de resistência do povo guineense, que parece reflorescer delicadamente a cada dia que passa.

O velho Papai, personagem de grande centralidade no romance, é imperativo:

Segue os conselhos das mulheres garandis ${ }^{25}$ e faz todas as cerimonias para que N'Dingui possa dormir em paz. É preciso lavar o sangue derramado pelo N'Dingui na Luta. Todos nós temos de o fazer. Penso fazê-lo assim que tiver possibilidades. Infelizmente ele não teve tempo para tal e é a ti que compete esta tarefa (idem, p. 16).

\footnotetext{
${ }^{25}$ Mulheres garandis, em outros termos, significa mulheres velhas.
} 
A cerimônia evidencia um conflito simbólico que opõe formas tradicionais e formas modernas de vida. Ela faz parte de um conjunto de conflitos sutis que ameaçam a vida comunitária da população guineense. Por isso, o descarte de cerimônias tradicionais pode causar ainda mais estragos culturais no país, pois, quando isso acontece, não sucede nada de bom nem para eles (os mortos) e nem para nós (os vivos).

Benaf, após alguns anos de vivência na Europa, anos em que praticou o individualismo mais tacanho, havia-se transformado "num ser desumano, num materialista interessado nos sucessos pessoais, saudoso das grandes cidades de luzes por todos os lados, dos automóveis, dos gigantes de betão armado", (idem, p. 17). Benaf ficou de novo sozinho vendo o velho Papai como sonhador, pois, no seu entendimento, Papai estava ali apenas para se libertar das terríveis contradições que o afrontavam e para cumprir um rito a que nada de sentimental o ligava.

Ao mergulhar o seu olhar no caixão do seu tio, a personagem Benaf ainda tentou imaginar como teria sido possível que um semianalfabeto pudesse ter sentido a necessidade de lutar por algo transcendental. A partir desse pensamento, passa questionar o seguinte: como foi possível ter abandonado tudo para pôr a vida em perigo? Mas N'Dingui abandonou o quê? Afinal, o tio teria tido alternativa? O que seria N’Dingui sem essa luta? O que seria ele, Benaf, o jovem doutor, sem a luta desse seu tio? O que significou a luta para esta gente? Tantos lutaram ou estiveram na luta acompanhando intelectuais que, como ele, tinham por missão enquadrar as massas? Como explicar que dum grande combatente tenha surgido um miserável?

Neste contexto de discussão, parece-nos que o personagem Papai representa a velha geração em Bissau hoje, uma geração que entra em contradição com o mundo moderno, com o mundo da nova geração que Benaf representa, conforme trecho abaixo:

[...] O velho até era interessante, simpático, mas os temas eram sempre os mesmos, a fazer lembrar o outro lado da consciência, precisamente o lado que ele estava interessado em eliminar. $O$ velho falava-Ihe de princípios que nortearam uma geração que acreditou no sacrifício individual como forma suprema, do espírito humano, enquanto que ele vinha de sítios onde o culto do ego estava sendo erigido em estátuas de pedras e cal. $\mathrm{O}$ contraste entre esses dois mundos era enorme e para Benaf o desenvolvimento significa nada mais nada menos do que cortar duma vez por todas com o mundo do velho e as suas amarras morais (idem, pp. 153-154). 
É importante compreender que os problemas da pós-independência e a hipocrisia dos governantes guineenses em relação aos heróis da independência são anunciados em Kikia Matcho logo no começo do romance, através de um comunicado lacônico a respeito do falecimento do N'dingui Có. Diz-nos o narrador: "O comitê do partido [PAIGC] do Sector Autónomo da Cidade de Bissau apresenta à família enlutada as suas mais sentidas condolências..." (idem, p. 5).

O anúncio da morte do ex-guerrilheiro N’Dingui, abandonado pelo Estado guineense e sem o mínimo apoio, nos aponta a tensão social que vem ocorrendo ao longo do tempo. O desencanto e o desprestígio, incorporados à cerimônia fúnebre como se a morte do ex-combatente fosse a morte do próprio projeto de nação, compõem o eixo a partir do qual se desdobra o romance.

Papai, o personagem amigo do morto N'dingui, começa por lamentar a desigualdade social presente no país, expondo a situação que provoca a continuidade da exploração do povo guineense pelos seus governantes:

[...] Talvez tenha sido um dos nossos erros, criamos condições de tal modo que ninguém sabe quem é quem e quem explora quem e em nome de quê e de quem se dá essa exploração. Uma coisa é certa: a exploração continua a existir, uns comem melhor do que os outros, uns têm boas casas, bons carros e outros nada, nem de toca-toca conseguem andar e só puxando carretas no mercado de Bandim conseguem sobreviver! (idem, p. 134).

Indignado com toda essa situação, Papai lamenta: "se o próprio Comandante Cabral voltasse e visse o que está a acontecer com seus combatentes e flores ${ }^{26}$ da luta" (idem, p. 60), com certeza estaria perplexo e muito triste com os atuais governantes do seu país, como bem expõe Moema Augel, citando Homi K. Bhabha: "Tais dias que fantasmagoricamente assombram nosso tempo e nossas pátrias confrontam nosso senso de progresso com o desafio do escombro" (BHABHA apud AUGEL, 2007, epígrafe). Isto significa que, nestes tempos de esquecimento, as medalhas tornaram-se o único instrumento capaz de chamar atenção para os combatentes que haviam ficado a sós com as medalhas para recordação (BARROS, 1999, p. 117).

Quando a luta acabou, o personagem Papai parecia ter a esperança de que os antigos combatentes fossem condecorados como heróis por todos, mas tudo ocorreu de modo inverso e a realidade dura dos tempos de hoje teima em manter aquela esperança longínqua. Agora "só lhe resta o comboio da independência que Ihe havia escapado" e a sua "magra pensão de Combatente

\footnotetext{
${ }^{26}$ Flores era o termo com o qual ele se referia às crianças.
} 
que recebe do Estado e que não chegava para comprar um saco de arroz" (idem, p. 15).

A barra estava pesada em Bissau e, sobretudo com o Ajustamento, a coisa estava a endurecer para os citadinos. Os Papás, quando existiam, não tinham quaisquer condições para vestir os filhos. "Duburia ${ }^{27}$ era a palavra de ordem em casa e não só" (idem, p. 47). Ainda acrescenta o narrador: "ninguém questionava a origem do sapato novo, do vestido, do cabelo postiço! Havia sempre um tio desconhecido que pagava por tudo! Hipocritamente a mãe calava e o pai fingia não se dar conta do que se passava à sua volta" (ibidem).

A situação econômica que o país vivia, resultado de uma má gestão dos recursos destinados ao desenvolvimento social do país, teria motivado o surgimento de uma nova classe de ricos aliada com antigos revolucionários. Dessa aliança, resultava uma classe social guineense composta por empresários e classe média alta (os matarnidos) - isto é, por aqueles que dispunham de influência política e econômica para engordar suas contas bancárias com a corrupção. Sobre essa organização, o narrador descreve:

\begin{abstract}
A pobreza do país refletia-se também no atraso com que a moda chegava aqui [...] Era preciso aproximar-se dos novos ricos da praça, os licenciados com algum dólar de poupança das missões, os funcionários médios, os coveiros da Função Pública, gastando o fruto dos sucus di bass ${ }^{28}$, e por fim, os empresários feitos à pressão pela onda liberalizante com os pesos made empréstimo para nunca mais pagar! (idem, p. 48)
\end{abstract}

$\mathrm{Na}$ contraface de tal quadro de privilégios, é possível citar os campos inferiores da formação. O primeiro é o dos matarnidos. O termo é utilizado por empréstimo do crítico literário Jorge Otinta, segundo o qual não existem ricos no país, mas, sim, matarnidos, pessoas que dispõem de "influência política e econômica, bem lá suas contas bancárias gordas, fruto da corrupção a que o país se tornou celeiro" (2011, p. 136). O segundo campo é o dos $n^{\prime}$ djeñerus ou n'djeñadus, termos que designam "os que estão relativamente bem em termos financeiros" (ibidem). Por fim, na parte mais baixa da formação, temos os kansadus, que, nesse contexto, são como os restos; ou seja, são as pessoas inconformadas com os resultados de uma crise social desumana. Esta crise que o país atravessa afeta, como em outros países, ainda mais as pessoas de zonas periféricas (ibidem).

\footnotetext{
${ }^{27}$ Duburia tem significado de safa ou de desenrascanço.

${ }^{28}$ Sucus di bass significa lucros.
} 
No horizonte da ficção de Filinto de Barros, esse complexo social gera grande estranhamento. A personagem jovem e intelectual Benaf, em Kikia Matcho, devido ao seu desenraizamento com relação ao continente africano e também à mística do continente híbrido, resultante da civilização moderno-cristã, surge, no romance, como um indivíduo assimilado na Europa.

A sua visão de mundo parece jamais entrar em sintonia com as práticas tradicionais africanas, pois, para ele, "paganismo e o cristianismo" juntaram-se não só para se tolerarem, mas para se "complementarem! É assim a África, o continente da vida, o continente que em vez de repudiar as influências externas acaba por as assimilar, transformá-las e fazer delas traços culturais à maneira", (BARROS, 1999, pp. 108-109). O personagem N’Dingui, por seu lado, é muito distante da igreja devido a sua "formação marxista da luta". Vale lembrar que, devido a esse processo de hibridização entre cristianismo e espiritismo africano, é notável no romance Kikia Matcho que durante a realização de toca-choro juntaram o caixão ao sacrifício do porco, uma vez que o porco morto deve passar por cima do caixão.

De acordo com a opinião de Johannes Augel (1996, p. 139), apesar de um dos propósitos da luta de libertação ser o de garantir direitos iguais a todos os cidadãos - como o de acesso à educação, à saúde, à justiça e ao lazer —, ou seja, o de criar condições favoráveis para a satisfação das necessidades básicas da população e para a garantia de melhores condições de vida para o guineense, os desvios de trajetória no pós-independência culminaram em privilégios, principalmente direcionados à elite emergente:

\begin{abstract}
Para falar a verdade, o mal vem de muito [anos] atrás. O país teve uma elite intelectual de causar inveja [riqueza] a qualquer país africano. [...] Elite que nunca soube aliar-se às elites rurais, tradicionais. [Elite que se] criou a mentalidade da exclusão, da intolerância. O poder de momento não podia aceitar uma opinião diferente da sua, a qual até era capaz de mudar depois, mas sem e admitir e sem voltar a chamar os entretanto excluídos. [...] Tomaram-se intelectuais com vergonha de o ser. Não exerceram o seu papel de intelectuais, aqueles que mostram o caminho (PEPETELA, 2000, pp. 315 -316).
\end{abstract}

Em relação à garantia dos pressupostos pelos quais se havia lutado, a sensação é a de frustração, pois se verifica uma certa repetição das práticas da época da colonização. Essa contradição levou o pesquisador Johannes Augel a concluir que o "Estado não pode excluir a longo prazo a massa, como aconteceu na Guiné-Bissau, porquanto esta situação é suscetível à acumulação de problemas que resultam em revoltas sociais e conflitos armados, aliás, como vem acontecendo nos dias atuais" (AUGEL, 1996, p. 151). 
O problema da desestruturação ou da fragmentação da elite nacional iniciou-se no processo revolucionário. A passagem a seguir, do romance $A$ geração da utopia, ilustra a crítica que o guerrilheiro faz sobre os rumos tomados para a condução da guerra de libertação nacional pelos dirigentes do Movimento revolucionário:

Nuns, é para se enganarem; são os idealistas. Noutros, é para enganarem os outros; são os vivaços. Tudo uma aldrabice. Aqui estou eu, perdido, a sofrer da fome e do frio, sabendo apenas que a salvação está no leste. Para quê? Uns tantos no exterior utilizam o meu sacrifício e o de tantos outros para chegarem aos países amigos e receberem dinheiro. Desse dinheiro, metade vai para os seus bolsos e dos parentes e amigos. A outra metade serve para aguentar a guerra. [...]não é por estarem interessados em libertar o país. Já fui parvo, já acreditei na boa fé de toda a gente. Agora já não me levam. Foi a última vez que vim combater. Se pensam vou voltar ao interior estão muito enganados. Vão lá eles, os donos da guerra. Vão ver se se pode lutar assim, sem mantimentos, sem povo, com guerrilheiros que fogem ao primeiro tiro. Claro, vão dizer, se os guerrilheiros não são corajosos, é porque os responsáveis não os moralizam. Mas como moralizar um homem que se apercebe de todas as injustiças? Vão dizer, isso é influência da propaganda inimiga, os pequeno-burgueses meteram-se na guerrilha... Que somos nós todos senão pequeno-burgueses? Se é propaganda do inimigo, ela constata uma realidade. Ou o inimigo é sempre mentiroso? (PEPETELA, 2000, pp. 18-19)

Em síntese, defendemos a hipótese de que todos os personagens caracterizados como guerrilheiros no romance Kikia Matcho demonstram desalento, mágoas e tristezas em relação à realidade sociopolítica da GuinéBissau.

\section{3}

\section{A representação da imagem do polvo e de Kikia}

Filinto de Barros e Pepetela introduziram a simbologia do polvo e do Kikia como forma de apresentar o mundo cultural e tradicional africano. Essa estratégia lhes serve, nos romances abordados, para estabelecer as relações das personagens com o passado e com o presente.

A observação das características biológicas de um polvo pode ser interessante para compreender a eleição dele como animal simbólico útil aos interesses narrativos e ideológicos de Pepetela quando o elegeu. Afinal, "o polvo é um molusco marinho que possui oito braços fortes, isto é, é molusco octopoda" e "tem o corpo mole e sem esqueleto interno/externo" (OTINTA, 2011, p. 235). Otinta afirma que o polvo, para se defender de qualquer que seja o perigo, 
"dispõe duma capacidade singular de largar uma espécie de tinta como sendo sua forma de camuflar-se". "É também autônomo em seus braços" (ibidem).

A coruja, por sua vez, também segundo Otinta, "é uma ave estrigiforme e alimenta-se de pequenos mamíferos, em especial espécies roedoras, insetos e arranhas" (ibid.). No imaginário da maioria das populações, acredita-se que ela tem a capacidade de adivinhar a morte - augúrio que estaria relacionado com o seu pio ou com o seu voo.

Neste subcapítulo, objetivamos traçar uma análise para compreender as representações simbólicas da imagem do polvo no romance $A$ geração da utopia, de Pepetela, e do kikia no romance Kikia Matcho, de Filinto de Barros. Partimos, assim, duma relação que nos leva à análise do cenário sociocultural de Angola e Guiné-Bissau nos anos 70 a 80 - cenário que é reconstituído literariamente nos livros selecionados para esta dissertação.

Em relação ao polvo, figura que representa o medo e o temor que assombrava os personagens Aníbal e Sábio depois dos acontecimentos da luta, pode-se dizer que ele também representa a corrupção, o desencanto, a distorção de ideais e o massacre da concepção de nação. Rita Chaves destaca do livro de Pepetela:

[...] um episódio contado por ele a Sara, no primeiro capítulo, Aníbal que, orientado pelo seu desencanto retira-se para a praia da caotinha, mergulha naquelas águas sempre mobilizado pelo desejo de reencontrar o polvo, o enorme polvo que sua memória convertera em identidade mitológica. Para aquele pedaço do país, afastado da capital e de qualquer centro de decisão, fica transferido o palco onde se vai dar um grande combate, o combate de um homem disposto a preservar-se inteiro com seus próprios monstros, com seus medos e seus limites (1999, p. 229).

Nesses termos, acreditamos que a personagem Aníbal hesita em relação à responsabilidade de enfrentamento do novo sistema estabelecido em Angola e em relação à exigência de fidelidade aos princípios que orientavam à práxis revolucionária - exigência direcionada, sobretudo, aos seus companheiros. $O$ ato de matar o polvo interliga as desilusões ocorridas após a colonização. Também com o polvo encena-se o exílio de Sábio, um exílio que representa o das pessoas que fugiram de Angola após a luta. Assim, consideramos que os exílios não resolvem os problemas, mas sim o diálogo e a conscientização das massas a fim de pôr o interesse da nação em primeiro lugar.

Kikia, na língua crioula guineense, significa "coruja", ave noturna que, no imaginário guineense, correlaciona-se com a maldição. Sendo assim, a sua presença noturna na sociedade guineense remete a população para a 
anunciação de algo errado, para um prenúncio do mal. Portanto, o seu aparecimento metafórico no romance representa a situação de uma maldição da qual, parece, ninguém pode escapar.

O aparecimento do kikia no romance é notável: ele ocorre justamente na noite de sexta-feira em que morreu o ex-combatente $N^{\prime}$ dingui Có, sendo testemunhado pela sobrinha Joana, em Lisboa, pelo sobrinho Benaf e o seu amigo Papai, em Bissau, e simboliza "o despertar da consciência individual/coletiva da população numa revolução da situação da instabilidade política que vem ocorrendo desde os anos 80", conforme ressalta Otinta (2011, p. 15). A imagem de kikia agourento caracteriza a figura dos políticos do país. Se o personagem Papai representa o país, Benaf e Joana simbolizam os anos da pós-independência.

Como em muitas culturas africanas, podemos observar que existe uma ambiguidade em relação à figura da coruja. Na sociedade guineense, o kikia não é apenas uma ave, pois tem o seu significado ligado à tradição - no contexto do romance, podemos percebê-la como disputa de poder e conflito político. Para Benaf, porém, que não compreendia as coisas das tradições africanas e também não reconhecia os males feitos ao país, o kikia é apenas uma ave:

\footnotetext{
Olhou para o relógio, fechou o rádio portátil e decidiu partir, sem antes ter atirado uma pedra para afugentar um mocho - Kikia, para os da terra - que teimava em poisar na janela do seu quarto. Benaf achou estranho uma ave nocturna a voar àquela hora da tarde, mas limitou-se a atirar a pedra (BARROS, 1999, pp. 8-9).
}

Cabe-nos buscar compreender, durante esta análise do romance, o porquê da presença da figura do kikia, uma ave de mau agoiro - e, como veremos, não poderia ser outra ave no horizonte narrativo. Queremos entender que mufunessa é esta. Por um lado, a nossa hipótese não se distancia da noção de que o escritor Filinto de Barros toma consciência da modernidade guineense e, por isso, critica a mesma sociedade por meio dos seus representantes. Por outro lado, a imagem do kikia serve para evidenciar que o personagem Benaf não compartilha do imaginário guineense (que entende o kikia como ave de mau agoiro) e, neste sentido, não é capaz de sentir como um guineense ou como um africano, não é capaz de ler os símbolos que surgem à sua frente. Assim, Filinto de Barros ilustra a realidade dos guineenses que, no tempo presente da narrativa, não sentem o mundo como guineenses, mas como indivíduos eurocentrados orientados por uma razão estranha à tradição local. 
Dessa forma, depois de situar o seu romance num ambiente do mundo dos vivos mesclado com multidões de kassissas (espíritos malignos), Filinto de Barros nos provoca a compreender a situação do país, motivo pelo qual esses kassissas metaforicamente representam políticos que sustentam a situação social miserável.

$\mathrm{Na}$ Guiné-Bissau, sabemos que a instabilidade política é profunda e que as causas dessas instabilidades, também profundas, nunca foram removidas desde a independência até os dias atuais. Por isso, o diálogo aberto e de boa-fé é o fator prioritário para que seja possível superar diferenças e divergências que existem nos órgãos de poder e de Estado. Ou seja, o diálogo deve prevalecer na abordagem das questões para que instituições de Estado possam funcionar harmoniosamente no quadro da solidariedade e da cooperação interinstitucional que se impõem num Estado democrático. A partir desse ponto de vista, a narrativa se desdobra e abre caminho para diversas reflexões:

\begin{abstract}
As pessoas afastaram-se cabisbaixas, pensativas: a cena tinha-as impressionado bastante e, sobretudo, a ameaça dum conviver com gente doutro mundo continuava a existir. Todos olhavam para Papai. Era ele quem devia tomar as medidas necessárias. Mas que medidas? A alma pedia cerimónia, mas que cerimónia? E quem devia fazê-la? Papai sabia que não estava em condições de fazer qualquer cerimónia (idem, p. 124).
\end{abstract}

A falta do interesse do personagem Benaf pela cerimónia fúnebre do seu tio remete-nos imediatamente para o seu egoísmo e para a sua aculturação ao mundo europeu. Por isso ele é amaldiçoado a não colaborar com o desenvolvimento do país. Do outro lado, os personagens Papai e Joana representam as vítimas de pessoas como Benaf. Já o N'dingui aparece como o morto transformado em kassissa, porque é escolhido para corrigir e mudar a situação em que vive o país. Diante dessa situação, ele precisa de uma cerimônia para libertar-se do mal e purificar-se dos erros cometidos durante a luta, conforme retrata a personagem Baifaz durante um diálogo com o velho Papai a respeito da voz que ele ouviu do N'dingui:

Eis o problema! Ele (N'dingui morto transformado em kassissa) mesmo não sabe explicar! Diz que é preciso fazer uma cerimónia, mas não especifica! Só fala de cerimónia e diz que tem de ser já! [...] Não brinques, Papai! A coisa é séria. Nenhuma alma regressa por regressar! Kassissa quer dizer castigo, quer dizer almas ruins, quer dizer gente que cometeu coisas terríveis na sua passagem por cá (idem, pp. 126-132). 
Não se trata de simples torna boca [que significa promessa a pagar], mas sim de um kikia com rosto humano; aliás, com rosto de alguém que acabou de morrer, mas que ainda não foi enterrado.

Com a sequência de graves problemas no país após o golpe de 14 de novembro de 1980, Barros indica que a alma de N’Dingui, após a cerimonia de toca-choro, foi abandonada por Deus de novo, talvez pela razão de ele participar da corrupção antes deste primeiro golpe que o afastou do poder nos anos 80, como se pode verificar no trecho do diálogo entre os personagens:

[...] o que é que o N'Dingui poderia ter cometido de tão terrível para a sua alma estar nesta situação? - Calma, Grã [Papai], não ponhas a mão no fogo por ninguém! Muita coisa aconteceu nesta terra depois da independência. Durante a Luta, a dinâmica do processo permitia detectar as falhas imediatamente. Mas depois que a guerra acabou, tornou-se mais difícil saber o que cada um anda a fazer. Se calhar N'Dingui fez parte dos que se afastaram de Cabral [os que se pautaram pela corrupção] e passaram a servir-se do partido em vez de o servirem. - Não posso crer! N’Dingui passou os últimos anos na tasca da Mana Tchambú, Tia Burim Mudjo, sempre a cair de bêbedo! Dantes encontrávamo-nos todas as tardes para dar um dedo de conversa! - Até parece que dormias com ele! Algum dia N'Dingui te contou o que fazia na calada da noite?! Olha que ele foi visto muitas vezes a entrar no edifício da segurança em horas muito impróprias (idem, pp. 132-133).

Anos depois, após o golpe de Estado de 1980, N'Dingui perdeu todas as condições que tinha e passou a enfrentar uma situação complexa de vida que o levou a cair em profundo desespero. Ao mesmo tempo, arrependeu-se dos erros cometidos com o seu povo. Por isso, escolheu a bebida alcoólica da barraca Tia Burim Mudjo, de Mana Tchambú, para mata flema ${ }^{29}$, para se libertar do peso do subconsciente e para obter um refúgio. A hipótese é de que isto teria provocado a sua morte, fazendo com que a sua alma esteja impedida de se juntar às almas daqueles que partiram antes dele. Voltou, como castigo, para convencer o amigo Papai a levar a sua mensagem aos políticos, tendo em vista levá-los a pôr um fim às práticas de barbaridade.

N'Dingui era um dos agentes da segurança que faziam serviços impróprios, como, por exemplo, o de decidir quem devia ser fuzilado durante a noite. Geralmente, essas pessoas são consideradas traidoras do projeto da revolução.

[...] a mente simplória de Papai não podia enxergar mais longe e descobrir os beneficiários últimos das acções criminosas de N’Dingui, os verdadeiros autores,

\footnotetext{
${ }^{29}$ Mata flema significa para atenuar a dureza da nova realidade. Cf. OTINTA, Jorge de Nascimento Nonato. Kikia Matcho. O desalento do combatente, Filinto de Barros. Revista Crioula - no 08. Novembro de 2010, p. 2.
} 
que, com o seu poder de antecipação, criaram as condições para que surgissem abomináveis N'Dinguis [Chefes corruptos do período pós independência] a reporem a ordem revolucionária, uma revolução que se autodestruiu quando começaram a surgir antecipadores dos acontecimentos [chefes que fazem desenhos de planos à corrupção]. [...] se o processo [o que quer dizer fuzilamento de conterrâneos que "traíram" a luta] era certo e justo, porquê fazê-lo na calada da noite longe dos olhos das massas, as mesmas massas de quem tanto se falava na revolução e para quem todo o poder era constituído? [...] Afinal, N’Dingui fugia da sua própria consciência, fugia da máquina que, tendo-o transformado num monstro (idem, pp. 135-136)...

A morte do combatente N'Dingui e o seu reenvio à terra transformado em kassissa parece representar um aviso do passado, quiçá do próprio Cabral, sobre pôr um fim à corrupção. É o aviso de Cabral a respeito da dissolução das utopias iniciais. É preciso uma cerimônia para se libertar do caos.

O personagem Papai, como N'Dingui, sofreu as consequências do impacto da discriminação por parte do poder político pós-independência. Vale ressaltar que, no momento da luta, ele estava à frente da mobilização das pessoas para se unirem e lutarem contra a colonização portuguesa até vencer os "brancos". Contudo, tudo isso veio a resultar em desentendimento entre os conterrâneos e tudo parecia indicar que não havia importância em lutar por esta causa, fato que é confirmado num diálogo entre ele e seu amigo Mancabo:

[...] chamas a isto a transformação? Eu não conheço isto antes da guerra, mas chamar a isto praça é um insulto às praças. Contaram-me que, com os colons, havia bancos para as pessoas se sentarem, jardim, e até uma estátua! - Então não tens olhos para ver os bancos? Não vês vestígios de jardim? - Vestígios, Grã? Estes ferros torcidos eram bancos? Puxa vida, nunca pensei nisso!... — Isto era lindo, Mancabo! Pondo de lado a terrível estátua dos brancos, o ambiente era agradável, diferente de todas as cidades africanas que conheci, e olha que não foram poucas! E agora o que vejo, meu Deus?! Onde vamos parar, Mancabo? Ruína, só ruína (idem, p. 103).

Segundo o personagem Papai, "as palavras de ontem já não têm aquela força para nos empurrar para frente" (idem, p. 105), pois a falsidade do Estado a cada dia está a crescer - por nepotismo, como constatou o próprio Papai ao se dirigir para o Ministério das Finanças a fim de avisar a morte do N’Dingui. O personagem Papai, ao chegar ao Ministério, encontrou muitas pessoas intitulando-se ex-combatentes e logo ficou indignado, como revela o trecho seguinte:

[...] Oh, Mancabo, cheguei a temer não encontrar alguém conhecido! Diz-me uma coisa: esta gente disse-me que eram combatentes, mas eu não me lembro da cara deles. Tu conheces alguns? - Bom, tenho visto alguns ultimamente nestas andanças de vaivém nas finanças, sobretudo com o aproximar das mudanças. Mas descansa que, por maior esforço que faças, nunca hás-de lembrar-te deles - 
Porquê, se são combatentes! Estou certo de que já nos cruzámos, dado que, como sabes, estive em todas as frentes, visitei todas as bases, tanto de guerrilha como do povo, de norte a Sul, de Kitafine a Boé. - Eu sei, eu sei, camarada Papai! Eu ainda me lembro bem de quem foste e de quanto fizeste pela nossa Luta. A questão é que esta gente nunca participou diretamente na Luta. Uns pertenciam às tabancas e limitaram-se a carregar as balas, de vez em quando. Outros estavam do lado dos tugas e, quando a guerra acabou, passaram a viver nas novas tabancas, fabricadas pelo regime de Luís Cabral. - Então, o que fazem aqui? A pensão não é só para aqueles que estiveram enquadrados nas fileiras do partido? Sobretudo, como é isso de Majores e Capitães. - É verdade, camarada Papai. A questão é que isto está difícil. Campu Quinti [dificuldades de hoje], camarada Papai! Hoje para ter divisas basta pagar algum dinheirinho à gente de Amura [Fortaleza de Amura. Hoje, Quartel General], levar uma fotografia e pronto [dão-Ihe estatuto de ex-combatente]! É o que a maioria faz e assim até as cozinheiras são tenentes na reserva. O pior é que tudo isso vem dividir a pensão, já de si magra. Denuncia-se, mas ninguém liga, ninguém está disposto a queimarse nas urnas... - [Então, com tudo isto], que respeito tem o combatente hoje, se basta uns continhos e uma foto para usufruir das regalias de combatentes da liberdade da pátria? Como a cidade, adulterou-se tudo e todos. Ninguém tem respeito pela luta! Como era possível confundir os grandes da luta com os carregadores das balas? (idem, p. 100-106)

Lutando contra a nova realidade que o país atravessava por conta do novo sistema implementado no aparelho do Estado, também o personagem Papai se refugiou no alcoolismo, também na tasca de Mana Tchambú e também, enfim, com o objetivo de fugir do desencanto quanto aos descaminhos da revolução. Tudo isso para não ter que ver o que estava sendo visto pelos outros, para não continuar a ver a corrupção que os outros empreendiam e para, enfim, "manter intacto o seu eldorado mundo de Amílcar Cabral" (idem, p. 130) - ou seja, para respeitar os princípios da luta e não passar, ele próprio, pela corrupção.

A posição adotada pelo ex-combatente Papai é a de não deixar a corrupção vencer, muito embora ele mantivesse a convicção da era colonial, do mato e do combate. Por isso, ele continua a sonhar, esperançoso de que um dia tudo venha a mudar. Por pertencer ao grupo de ex-combatentes que nunca se pautaram pela corrupção durante a luta, sempre respeitou os princípios do Partido e dos seus chefes. Integra, o personagem, a velha geração de Bissau que, hoje em dia, entra em contradição com a visão da nova geração, como confirma o narrador no fragmento abaixo:

O velho [Papai] até era interessante, simpático, mas os temas eram sempre os mesmos, a fazer lembrar o outro lado da consciência o Papai relembra-se o passado glorioso, precisamente o lado que ele Benaf, representante da nova geração estava interessado em eliminar. $O$ velho falava-lhe de princípios que nortearam uma geração que acreditou no sacrifício individual como forma suprema, do espírito humano, enquanto ele vinha de sítios onde o culto do ego estava sendo erigido em estátuas de pedras e cal ideia europeia por ter vivido ali. O contraste entre esses dois mundos era enorme e para Benaf a nova geração o desenvolvimento significa nada mais nada menos do que cortar duma vez por 
todas com o mundo do velho não seguir a visão de Papai e as suas amarras morais (idem, p. 145).

É possível relacionar o que aconteceu ao personagem Papai, que perdeu tudo o que tinha devido à situação pós-independência, com a situação de outro ex-combatente desalentado, que concedeu entrevista por Fernando Cumba ${ }^{30}$ em 2016. Diz o velho guerrilheiro:

\begin{abstract}
Ora, após a instalação do PAIGC em Bissau, isto é, após a independência, assiste-se a uma onda de raptos e fuzilamentos de indivíduos que haviam abandonado o PAIGC, o partido; daqueles que se posicionaram contra o partido, estando ao lado dos colonialistas. Estas pessoas eram levadas para as matas e fuziladas e colocadas em valas comuns. Por outro lado, o golpe de estado de 14 de Novembro de 1980, liderado pelo então presidente, João Bernardo Vieira, "Nino ", [golpe que depôs Luís Cabral, presidente da Guiné após a independência, facto que levou à separação, anos depois, entre a Guiné e Cabo Verde em termos administrativos], acontecimento de 17 de outubro de 1985, uma "alegada intentona balanta" para derrubar Nino Viera, acontecimento que culminou com fuzilamento de altas personalidades do país em Julho de 1986, entre os quais: Paulo Correia (acusado ser orquestrador), Binhancarem Na Tchanda, Braima Bangura, N'Bana Sambú, Pedro Ramos e Viriato Pam; acontecimentos desumanos ligados à sociedade guineense que fazem afastar vários efetivos militares de quarteis; enfim, esses acontecimentos, cujos ódios desembocaram na revolta militar de 7 de Junho de 1998, que fez novo derramamento de sangue aqui na Guiné. Ainda, o golpe de estado de 14 de Setembro de 2003, que derrubou Kumba Yala, etc. Estes últimos deixaram o país sem rumo imediato até hoje. Tudo isto faz com que nós, tropas que lutamos para esta terra, sentimos cada vez mal! Perdemos tudo e tudo por causa da guerra da libertação Nacional. Muitos perderam família, vida, braços, perna, etc., mas não somos hoje bem vistos. Somente 15.000 francos. [Referia-se ao valor pago hoje aos ex-combatentes guineenses, por mês, relativo à pensão. Esses 15.000 francos equivalem a 23,07 euros] (2017, p. 64)
\end{abstract}

Segundo Cumba, Carlos Yalá, ex-combatente do PAIGC, que esteve presente na luta na frente sul do país, entrou para a luta em 1962, em Bissorã, e depois foi transferido, em 1967, para a frente Sul, onde se juntou aos outros comandantes, inclusive ao comandante Domingos Ramos. Cumba acrescenta que, na frente Sul, "o ex-combatente exerceu várias funções ao lado do seu comandante, Domingos Ramos, entre as quais Adjunto Comandante do efetivo militar presente em Komo durante a guerra" (ibidem). Atualmente, encontra-se numa situação de desalento devido à má governança dos atuais dirigentes da nação guineense. $\mathrm{Na}$ nossa leitura, é precisamente o conjunto desses combatentes que Filinto de Barros elege para trabalhar em seu romance Kikia Matcho. Acrescentamos, ainda, que é precisamente esse sentimento de desalento que faz com que os romances de Pepetela e de Filinto de Barros

30 Cf. YALÁ, Carlos. Situação atual de ex-combatentes da liberdade da Pátria. [Entrevista concedida a] CUMBA, Fernando Nhaga. O passado no presente e a literatura Guineense do Século XXI a partir do romance Kikia Matcho: o desalento do combatente. Dissertação de mestrado. Lisboa: Universidade de Nova Lisboa, 2017. 
possuam elos tão estreitos, uma sintonia no tempo e no espaço que nos permite compreender melhor as contradições que foram impostas pelas condições políticas e econômicas do pós-independência.

Na mesma entrevista concedida em 2016, o pesquisador Fernando Cumba percebe a situação diferente de outro ex-combatente conhecido, Mamadu Cisse, que lutou ao lado dos exércitos portugueses desde 1962, começando de Binar, Bissorá: "foi transferido para o centro de instrução de Bolama em 1968; em 1971 saiu de Bolama para quartel de Quebú, Sul do País, local onde ficou até à entrega em 1974" (idem, p. 69). Para o velho ex-combatente Mamadu Cisse:

\begin{abstract}
Tudo começou nos finais dos anos setenta e início dos anos oitenta! Digo, quando eles [PAIGC] instalaram-se em Bissau, iniciaram logo com julgamentos contra os "criminosos" [aqueles que lutaram contra os nacionais]! Dali, estes, a maior parte foi morta por fuzilamentos em lugares incertos, e as famílias perderam os bens desses. Ou seja, para além de perder o membro da família, tu perdes também o bem desse. Eu, como aquele que esteve na luta ao lado dos portugueses, consegui escapar-me da "história" devido ao meu primo que estava em Senegal durante o período da luta. Foi por lá que me abriguei! E só voltei cá em 1995, já no período da democracia multipartidária. Em 1995, um ano após as primeiras eleições democráticas. Aliás, eu não podia voltar para cá entre os anos oitenta e início da década noventa, eles iam assassinar-me porque o fenómeno durou quase até aos anos entre 1992 e 1993. O fim do fenómeno foi graças aos líderes políticos dos novos partidos que atacavam abertamente o regime, entre os quais: Koumba Yalá, líder do PRS, que era forte e corajoso em atacar os senhores no poder e outros. Efeitos de tudo isso, é que, para além de nós irmos para a luta sem o nosso consentimento ao lado dos portugueses, também perdemos com isso: primeiro é que, após a independência, muitos dos colegas perderam a vida devido às perseguições dos então governantes; segundo, foi porque perdemos os nossos bens - gado, residências, esposas etc. em detrimento dos senhores chefes de então; terceiro, é que não estamos a receber dos portugueses salários ligados à pensão a que deveríamos ter direito por lutarmos ao lado deles razão pela qual, após a independência, a maioria dos colegas foi alvo de morte; quarto e último, a Guiné atualmente não marcha! Este último faz com que todos nós, os guineenses, vivamos em miséria e sejamos mal vistos, hoje, pela maioria dos nossos parceiros estrangeiros. Por isso, eu diria que não valia a pena que houvesse uma luta contra os portugueses. E, também, espero que Portugal faça pagamento a todos os que estavam ao seu lado durante a luta! Visto que, costumamos ir à embaixada de Portugal, aqui em Bissau, para ver se conseguem fazer o pagamento, mas o responsável que se encontra no adito militar da embaixada simplesmente nos entregou as cadernetas há anos, mas sem fazer chegar o dinheiro. Alguns colegas que conseguiram oportunidades de ir até Portugal, conseguiram ser atendidos [indicando alguns nomes]. Ainda, tentamos pedir ajuda por parte de sucessivos governos guineenses para nos auxiliarem no assunto ligado a Portugal, mas nada! Agora, o que teremos como fim último, fazer sucessivas marchas a essa Embaixada para ver se nos atendem, senão, queixarse de Portugal! (ibidem)
\end{abstract}

No enredo de Kikia Matcho, essa situação ocorreu por meio do excombatente guineense Farim, que lutou ao lado dos portugueses: "Farim tinha feito a tropa com os tugas. Foi um kumandu com cinturão na rabada (BARROS, 1999, p. 61). Papai não tinha aceitado atuar com os tugas, convencido de que os 
dias da independência seriam melhores "do que aquilo que viveu atrás das sopas. Agora já é tarde e a ataia $^{31}$ serviu de refúgio e quem sabe se de sepultura" (idem, pp. 62-63). É importante ressaltar que Farim, apesar de ter lutado ao lado dos portugueses, também tinha conservado a sua nacionalidade. Isso porque não se identificava com os portugueses, mas sim com os guineenses, e ele representa os combatentes como os do caso de Mamadu Cisse. A esse respeito, acrescenta o narrador: "com a independência, Farim ficou satisfeito. Estranho, combateu com os independentistas, mas conservou no fundo seu nacionalismo nato" (idem, p. 61).

A partir do depoimento acima, compreende-se que Filinto de Barros conhece bem os meandros socioculturais e antropológicos do cotidiano guineense. Por isso, procura testemunhar, por vários prismas, a realidade coitidiana do país onde muitas pessoas não tiveram a oportunidade de operar mudanças necessárias - pessoas sem direitos na atual sociedade que, ontem, cumpriram seus deveres para com o povo, conforme sublinhou o crítico literário Jorge Otinta: "transformaram-se nos excluídos de hoje, que não são só os que vemos sem rumo nas ruas, mas também aqueles que acostumamos ao desterro nas suas casas, choram, resignadamente suas lágrimas, longe dos outros" (2011, pp. 228-229).

Analisemos a seguinte passagem, expressa como uma súmula do diálogo entre Papai e Farim, sobre uma cena que ocorre durante o enterro do N'Dingui. Nela, o narrador observa sabiamente o aspecto surreal da conjuntura:

\begin{abstract}
Que diferença havia mesmo? 'Kassissa' pobre, 'kassissa' rico! 'Kassissa' honesto, 'kassissa' ladrão! E Cabral? Não, não podia ser! Podia o Chefe de guerra também ele se transformar em Kassissa, em fantasma que ronda a pátria? Pois é, tal como disse o narrador. É possível que Farim estivesse certo. [Mas, em nome de Cabral, como sempre], era preciso salvar o país mais uma vez e assim cumprir mais uma palavra de ordem agora dada 'ironicamente' pelo seu, até há bem pouco tempo, amigo e companheiro da desgraça, N'Dingui, de quem os comandantes nem sequer se dignaram a assistir ao funeral. (BARROS, 1999, p. 148)
\end{abstract}

Faz-se necessário questionar por que é que a alma de Cabral passou? Se ele é chefe de guerra, o normal seria ficar à espera da cerimônia, como os outros, sobretudo N'Dingui. As 'Apilis' ${ }^{32}$ amparavam-nos, nunca se sentiam envergonhadas dos seus homens da cidade, diz-nos o narrador-escritor por meio da fala da esposa do Sissé:

\footnotetext{
${ }^{31}$ Ataia, neste caso, é o vinho feito de caju.

${ }^{32}$ Apili, na língua pepel, uma das étnicas da Guiné-Bissau, significa menina.
} 
Não tem problema algum! "Eu compreendo o meu homem" e, feitas as contas, é melhor ser assim [bêbado] do que ladrão! Isto faz parte da luta, do desencanto que todos nós sofremos ao não conseguirmos atingir os nossos objectivos. Aliás, o universo dos objectivos foi tão grande e tão díspar, que acabamos todos confundidos. Para "meu homem", esta é a solução que melhor se adapta à sua maneira de ser: cair fundo, mas de cabeça erguida (idem, p. 42).

Para resumir, apesar de a maioria dos ex-combatentes guineenses estarem decepcionados com a atual configuração política e econômica da Guiné-Bissau, nunca se deixaram de sentir orgulhosos pela luta de libertação nacional, sob a liderança de Amílcar Cabral, que não pôde assistir o ato que mais ansiava: a Independência do país. Alguns combatentes acreditam que, se Cabral não tivesse sido assassinado, o destino político da Guiné-Bissau estaria seguro, e em outro rumo, com menos instabilidade, porque ele representava, pelo menos aparentemente, a unidade do PAIGC na luta pelo ideal nacionalista do povo guineense. $O$ antigo combatente, outrora reconhecido como veterano da Pátria, é património da Guiné-Bissau, devendo ser valorizado e protegido como tal. 


\title{
CONCLUSÃO
}

\begin{abstract}
Assim as nossas raízes de ferreiros muitos antigos vão resistindo ao vento e à tempestade destes últimos tempos que, mais que o vento ou a areia do deserto, os experimenta os corpos e vai retorcendo as almas.
\end{abstract}

Ana Paula Tavares

A história política de Angola e Guiné-Bissau tem muitas influências na literatura produzida durante a independência e depois da independência dos respectivos países. Os autores da época da libertação retrataram, sempre com olhos aguçados, as situações sociopolíticas de ambos os países. Assim, durante a colonização reuniram suas vozes para criticar a marginalização e a opressão portuguesa. E, com a Independência, também não deixaram de criticar as mazelas que trouxeram os desencantos e as sucessivas crises políticas. Durante a nossa análise em $A$ geração da utopia e Kikia Matcho, verificamos como isso ocorre nas experiências temporais de Pepetela e Filinto de Barros, sobrepostas no espaço das suas respectivas comunidades quer no plano real vivido, quer no plano ficcional.

Também refletimos sobre o papel de Pepetela e Filinto Barros, dois escritores intelectuais, nas questões políticas, sociais e culturais de Angola e Guiné-Bissau, isto é, as críticas direcionadas às elites políticas desses países em tempos de autodestruição e de salve-se quem puder.

Esses motivos nos levaram a problematizar o seguinte: como é que isso aconteceu? Como é possível sair de um extremo para outro? O que definiria o papel dessas elites na política? Como são formadas essas elites? Qual é o lugar deles na sociedade? Qual é o propósito das ideias que surgiram após a luta anticolonial?

Ao analisarmos os aspectos da movimentação das elites no aparelho do Estado, constatamos que a dominação do poder veio a constituir-se como um objeto de interesse e disputa diretamente relacionado ao aumento da corrupção, bem como das sucessivas crises nessa mesma máquina, conforme nos apresenta o narrador de Filinto de Barros: 
O fim da odisseia não foi tão feliz como esperavam. A pensão era muito pequena, não dava para sustentar uma família de mais de seis bocas. Ao contrário do famigerado da luta [Marcelino] da Mata, o marido da Maria Amélia, vulgo N'male, não tinha sido tão operacional [contra o exército português]. Não matou com requintes de Malvadez, não se passeou com o cinturão de orelhas das vítimas, não bebeu sangue do inimigo, logo não teve direito a Medalha alguma (1999, pp. 141-142).

Ao que parece, no nosso modo de olhar, tudo indica que o objetivo de construir uma nação fundamentada nas mazelas do regime colonial não se chocou com as ideias do projeto revolucionário. Ao mesmo tempo, percebemos que o que há de comum entre as elites das políticas angolana e guineense é a permanência da desigualdade social, que de fato existe no seio das suas populações e que "faz com que a insegurança e a ameaça da violência sejam vistas como os principais fatores a exigir que algo seja feito para combater a pobreza e a desigualdade" (REIS, 2000, p. 150).

Pensando a partir dos romances analisados, e buscando formular conclusões a partir dos indícios que ambos levantam, nota-se que faltaria às elites da política a responsabilidade social e a fidelidade aos compromissos com as pátrias. O crescimento de grupos de pessoas que não concordaram com os projetos de "unidade nacional" e de (re) construção dos Estados nacionais seria uma das consequências dessas faltas.

Ainda neste estudo, percebemos que os romances em questão revelam, tanto no conteúdo quanto na estética/forma, as problemáticas da dicotomia tradição-modernidade. De certa forma, há cidadãos guineenses e angolanos que procuram preservar suas identidades culturais tradicionais como "patrimônio cultural", principalmente os que moram em zonas rurais e os que pertencem às gerações mais velhas (os anciões/garandis de casa ${ }^{33}$ ). Cada um deles procura manter essas práticas para não perder as raízes identitárias — ou seja, cada um deles transforma-se "no guardião das tradições ameaçadas pela civilização, pelo cristianismo de um lado e pelo islão de outro" (BARROS, 1999, p. 131).

Ao contrário das gerações aludidas anteriormente, temos as gerações mais urbanizadas, escolarizadas, impregnadas pelo modo de vida ocidental, gerações que procuram desprezar ou desconhecer, e até mesmo chegam ao ponto de não defender as crenças e os costumes tradicionais - dentre elas, a nova geração de capital, por exemplo. Sobre o assunto, Laura Padilha argumenta:

\footnotetext{
${ }^{33}$ No crioulo guineense, garandis de casa significa os velhos da casa.
} 
A leitura de uma série expressiva de romances editados nos últimos anos do século passado e nos iniciais do XXI comprovam, quando os recortamos pelo viés do espaço, acoplado ao do tempo, que a tradição ainda permanece sendo um elemento produtor de sentidos dos mais instigantes. Isso se explica pelo fato mesmo de que os sujeitos africanos, nesse tempo marcado pela intensa tempestade da globalização, não abdicam de reforçar o seu próprio repertório cultural $^{34}$.

Assim, torna-se pertinente afirmar que o Estatuto do Indigenato implementado nas últimas décadas do colonialismo em ambos os países, permitiu alguns privilégios aos assimilados ${ }^{35}$, dentre os quais destacamos: direito à escola, direito ao batismo, direito de comer na mesa como um branco e direito de usar chinelas na cidade, como descreveu o ex-combatente velho Papai num diálogo com o Benaf: "Ao lado de cada uma, as chinelas de borracha a lembrarem a passagem da civilização portuguesa que impunha o uso dessas chinelas na cidade. O processo de aculturação, baptizado de civilização, aconselhava a tal" (BARROS, 1999, p. 18).

Precisamente, são esses os elementos que ajudaram a consolidar a dicotomia gentio-civilizado sobre a qual se estabeleceram a descriminação social e o afastamento - quando não a aniquilação — das identidades étnico-culturais. É por isso que as sociedades angolana e guineense de hoje requerem a valorização das tradições ancestrais africanas e das suas marcas identitárias, conforme é propostado pelo homem preto, em uma conversa com o Baifaz, na qual ele se mostra interessado em buscar as suas origens na tradição local (guineense). Diz ele: "Qualquer dia vou dedicar o meu tempo a investigar donde

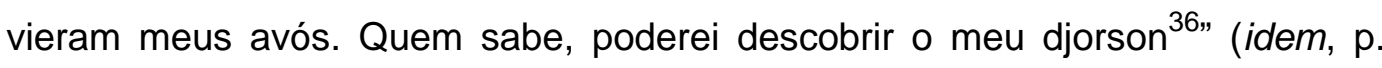
121).

Sendo assim, concluímos que há uma relação estruturante entre literatura, história, política e cultura de Angola e da Guiné-Bissau, relação que as obras de Pepetela e Filinto de Barros traduzem muito bem em narrativa ficcional. As obras de Pepetela e de Filinto de Barros, aliás, querem nos mostrar como ocorreu o

34 Disponível em: https://www.ueangola.com/criticas-e-ensaios/item/224-atradi\%C3\%A7\%C3\%A3o-e-a-transforma\%C3\%A7\%C3\%A3o-em-textos-romanescos-africanos. Acesso em: 25 fev 2021.

35 “Os conceitos do 'assimilado' e 'assimilação' refere-se a um instrumento legal do Estado Colonial português em vigor basicamente de 1917 a 1958 (ou até 1961). Ele promulgava-se aos indivíduos africanos negros o direito a uma 'cidadania concedida, desde já que atendessem algumas exigências: "africano que se considerasse 'civilizado' devia fazer um exame, respondendo a certas perguntas e deixando que uma comissão fosse à sua causa ver como é que vivia, se sabia comer como um branco, à mesa, se calçava e se tinha uma só mulher. Quando ele era aprovado, passavam-lhe um documento chamado o 'alvará de assimilação'” (CABAÇO, 2009, apud SARAIVA, 2013, p. 10).

${ }^{36}$ Djorson "é a origem linhageira dos pepeis, uma das etnias da Guiné-Bissau. São, ao todo, sete, os quais correspondem aos setes sobrenomes da sua população" (OTINTA, 2011, p. 281). 
processo da luta de libertação nacional em Angola e Guiné-Bissau e também como surgiram as desilusões, as corrupções, a invisibilidade dos excombatentes e a continuidade da pobreza após independência nesses países. Portanto, os tempos utópicos e distópicos nessas narrativas podem ser percebidos como "renascimento das esperanças", como nos deixou bem claro o narrador de Pepetela na seguinte afirmação: [...] "Como é óbvio, não pode existir epílogo nem ponto final para uma estória que começa por portanto" (PEPETELA, 2000, p. 327). Ou, no dizer da personagem Papai, em conversa com o seu amigo Farim, no final do romance Kikia Matcho: "Achas que não tenho motivo para me sentir preocupado. Não vês que tudo isso foi colocado sobre os meus ombros, se não esta terra vai encher-se de Kassissas! Tenho que mexer, mas não sei por onde começar" (BARROS, 1999, pp. 155-156). 


\section{REFERÊNCIAS}

ABDALA JUNIOR, Benjamim. "Notas sobre a Utopia, em Pepetela". In: Org. CHAVES, Rita e MACÊDO,Tania. Portanto Pepetela. São Paulo: Ateliê Editorial, 2009.

AFONSO, Maria Fernanda. O conto moçambicano: escritas pós-coloniais. Lisboa: Caminho, 2004.

AGUIAR E SILVA, Vitor Manuel de. Teoria da literatura. São Paulo: Martins Fontes, 1976.

ALMEIDA, Hilda Maria Ferreira de. Educação e transformação social: formas alternativas de educação em país descolonizado. 1981. 239f. Dissertação (Mestrado em Educação) - Fundação Getúlio Vargas, Rio de Janeiro, 1981.

AUGEL, J. "Democratização e a formação de elite". In: AUGEL, J. ; CARDOSO, C. (Orgs.). Transição democrática na Guiné-Bissau e outros ensaios. Bissau: Instituto de Estudos e Pesquisa-INEP, 1996.

AUGEL, Moema Parente. O desafio do escombro: nação, identidades e póscolonialismo na literatura da Guiné-Bissau. Rio de Janeiro: Garamond, 2007.

A Nova Literatura da Guiné-Bissau. Bissau: INEP, 1998.

BARROS, Filinto de. Kikia Matcho: o desalento do combatente. Lisboa: Caminho, 1999.

BENZINHO, Joana; ROSA, Marta. A Descoberta da Guiné-Bissau. [Guia Turístico]. Afetos com Letras - ONGD. Dezembro de 2015.

BERGSON, Henri. Matéria e memória: ensaio sobre a relação do corpo com o espírito. São Paulo: Martins Fontes, 2. ed., 1999.

BHABHA, Homi K. O local da cultura. Trad. Myriam Ávila, Eliana Lourenço de Lima Reis, Gláucia Renate Gonçalves. Belo Horizonte: Ed. UFMG, 1998.

. "A questão do 'outro'. Diferença, discriminação e o discurso do colonialismo". Trad. Caetano Lopes Jr. In: HOLANDA, Heloisa Buarque de. (org) Pós-modernismo e política. Rio de Janeiro: Rocco, 1991, 2ª ed.

BLANCHARD, Pascal. \& BANCEL, Nicolas. De l'indigène à l'immigré. Paris: Gallimard, 1998. 
BOSI, Alfredo. "Narrativas e resistência". In. Literatura e resistência. São Paulo: Companhia das Letras, 2002.

BOSI, Ecléa. Memória e Sociedade: lembrança de velhos. São Paulo: Schwarcz Ltda., 2001.

CABRAL, Amílcar; COMITINI, Carlos. A Armada da Teoria. Editora Codecri. Rio de Janeiro: 1980.

PAIGC: Unidade e Luta. Lisboa: Nova Aurora, 1974.

. A arma da teoria: unidade e luta I. $1^{\underline{a}}$ ed. Lisboa: Seara Nova, 1978, p. 234.

Análise de alguns tipos de resistências. Bolama: Imprensa Nacional, 1979.

CABRAL, Jorge. Os Marinheiros Da Solidão. Série literária, coleção KEBUR nํำ 7. Bissau: INEP / KEBUR, 1998.

CHABAL, Patrick. "O Estado pós-colonial na África de expressão portuguesa". In: Revista de estudos guineenses. Soronda: Instituto nacional de estudos portugueses $\mathrm{n}$ 15, 1993.

CARDOSO, Carlos. "A transição democrática na Guiné-Bissau: um parto difícil". In: AUGEL, Johannes. Transição democrática na Guiné-Bissau e outros ensaios. Bissau: INEP, 1996.

CARDOSO, Sebastião Marques. "Crítica da razão cultural guineense: um estudo sobre a representação da cultura em kikia matcho, texto ficcional de Filinto de Barros”. In: Revista Via Atlântica, São Paulo, n. 32, pp. 357-375, dezembro, 2017.

CARVALHAL, Tania Franco. "Intertextualidade: a migração de um conceito". Revista Via Atlântica, São Paulo, n. 9, junho, 2006.

CARVALHO, Juvenal. "Angola: a construção de uma nação". Caderno do CEAS. Revista crítica de Humanidades, n. 224, 2006. Disponível em: <https://cadernosdoceas.ucsal.br/index.php/cadernosdoceas/article/view/158>. Acesso em: 25/01/2021.

CARVALHO, Ruy Duarte de. A Câmara, a Escrita, e a Coisa Dita... Fitas, Textos e Palestras. Luanda: INALD, 1997.

O que não ficou por dizer. Luanda e Lisboa: Associação Cultural Chá de Caxinde, 2011.

CASCUDO, Fernando Luiz da Câmara. Angola: A guerra dos traídos. Rio de Janeiro: Bloch Editores S A, 1979. 
CHABAL, Patrick. "O Estado pós-colonial na África de expressão portuguesa". In: Revista de estudos guineenses. Soronda: Instituto nacional de estudos portugueses, 1993.

Vozes moçambicanas: literatura e nacionalidade. Lisboa: Veja, 1994.

- Las políticas de violência. In: Revista Académica de Relaciones Internacionales, UAM-AEDRI, abril, 2007.

.o Processo de Transição para o Multipartidarismo em Angola. In Vidal, Nuno \& Pinto de Andrade, Justino. Sociedade Civil e Política em Angola, enquadramento regional e internacional. Luanda \& Lisboa: Universidade de Coimbra \& Univ. Católica de Angola, 1aㅗ edição, 2008; $2^{\underline{a}}$ ed. 2009.

CHATTERJEE, Pharta. Comunidad imaginada: Por quién? História Caribe, vol. II, n. 7, pp. 43-52, 2002. Disponível em: http://www. Redalyc.org./pdf/93720704. Pdf $>$ Acesso em: 20/01/2021.

CHAVES, Rita. "O passado presente na literatura africana". In: Revista Via Atlântica, São Paulo, n. 7, 2004.

CHAVES, Rita. Angola e Moçambique: experiência colonial e territórios literários. Cotia: Ateliê Editorial: 2005.

A formação do romance angolano. São Paulo: Fundo Bibliográfico de L P, 1999.

Pepetela: romance e utopia na história de Angola. São Paulo: Universidade de São Paulo, 1999.

COSTA, Marceano Tomas Urem da. "A crítica literária sobre a literatura da Guiné-Bissau: considerações sobre um "suposto vazio". In: Mafuá, Florianópolis, n. 29, 2018. Disponível em: Mafuá » A crítica literária sobre a literatura da GuinéBissau: considerações sobre um "suposto vazio" (ufsc.br). Acesso: 18/01/2021. COUTO, Hildo Honório do; EMBALÓ, Filomena. "Literatura, língua e cultura na Guiné-Bissau: um país da CPLP”. In: Papia, Brasília, n. 20, pp. 1- 254, 2010.

COUTO, Mia. Um rio chamado tempo, uma casa chamada terra. São Paulo: Companhia das Letras, 2003.

À porta da modernidade, há sete sapatos sujos que necessitamos descalçar. Disponível em: http://www.pordentrodaafrica.com/cultura/mia-couto-a-porta-da-modernidade-hasete-sapatos-sujos-que-necessitamos-descalcar. Acesso em 24 dez. 2020. CUMBA, Fernando Nhaga. $O$ passado no presente e a literatura Guineense do Século XXI a partir do romance Kikia Matcho: o desalento do 
combatente. Dissertação de mestrado. Lisboa: Universidade de Nova Lisboa, 2017.

Disponívelem:https://run.unl.pt/bitstream/10362/23170/1/Disserta\%C3\%A7\%C3 \%A30\%20Final\%20\%28revis\%C3\%B5es\%20a\%20partir\%20de\%20sugest\%C3 \%B5es\%20do\%20Arguente\%29.pdf.

DJALÓ, Tcherno. Lições e Legitimidade dos Conflitos Políticos na GuinéBissau. Bissau: INEP, 2000.

DUNDÃO, Sérgio Manuel. Conflito armado e Construção do Estado: Uma comparação entre Moçambique e Guiné-Bissau. Dissertação de mestrado. Lisboa: Universidade Nova de Lisboa, 2014.

FANON, Frantz. Os Condenados da Terra. Tradução Enilce Albergaria Rocha, Lucy Magalhães. Juiz de Fora: Ed. UFJF, 2005.

FERREIRA, Manuel. O discurso no percurso africano. Lisboa: Plátano, 1989. FISCHGOLD, Christian Rodrigues. "Ruy Duarte de carvalho e o paradoxo do moderno estado-nação angolano". In. Revista Transversos. Dossiê: Reflexões sobre e de Angola - Inscrevendo saberes e pensamentos, n. 15, pp. 194-212, abril, $2019 . \quad$ Disponível em: https://www.epublicacoes.ueri.br/index.php/transversos/article/view/42042/29152. Acesso em: 12/11/2020.

GRAMSCI, Antonio. Lettere dal Carcere, 2 vol, no 02 . Palermo: Ed. Sellerio, 1996.

HALBWACHS, Maurice. A memória coletiva. São Paulo: Ed. Vértice/Ed. Revista dos Tribunais, 1990.

HALL, Stuart. A Identidade Cultural na Pós-Modernidade. Tradução Tomaz Tadeu da Silva, Guaracira Lopes Louro. 11. ed. Rio de Janeiro: DP\&A, 2006. "Quem precisa de identidade?". In: SILVA, Tomaz Tadeu da.

Identidade e diferença: a perspectiva dos Estudos Culturais. Petrópolis: Editora Vozes, 2006.

Da diáspora. Identidades e mediações culturais. Organização: Liv Sovik. Trad.: Adelaine La Guardia Resente et al. Belo Horizonte: Editora UFMG, 2011.

HERBST, Jeffrey. War and the State in África. International Security, 14 (4), 1990.

IMBALI, Faustino. Os efeitos sócio-económicos do programa de ajustamento estrutural na Guiné-Bissau. Bissau: INEP, 1993.

JONG, Joop T. V. M. de. "O Irã, o fulano e as doenças". In: Soronda: Revista de Estudos Guineenses, n. 5, janeiro, 1988. 
JÚNIOR, Maurílio Alves Rocha. "Guerrilheiros da utopia, personagens da distopia: breve estudo comparado de A geração da utopia e um rio chamado tempo, uma casa chamada terra". In: Revista Africa e Africanidades, n. 25, out-dez, 2017.

KOUDAWO, Fafali, MENDY, Peter Karibe. Pluralismo político na GuinéBissau: uma transição em curso. Bissau: INEP, 1996.

LARANJEIRA, Pires. "Mia Couto e as literaturas africanas de língua portuguesa". Revista de Filologia Românica. Anejos, 2001.

Literaturas Africanas de Expressão Portuguesa. Lisboa: Universidade Aberta, 1995.

LEITE, Ana Mafalda. Oralidades \& escritas pós-coloniais: estudos sobre literaturas africanas. Rio de Janeiro: Eduerj, 2012.

LOPES, Carlos. Transição Histórica na Guiné-Bissau. Bissau: INEP, 1987.

- "O legado de Amílcar Cabral face aos desafios da ética contemporânea". In: Jornada Internacional de Cinema da Bahia. Trocas culturais afro-luso-brasileiras. ARAÚJO, Guido (Org.) \& RUBIM, Albino Canelas (Coord.). Salvador: Contraste, 2005.

MACHADO, Carolina Bezerra. Relações de Poder em Angola: Uma leitura dos romances de Pepetela (1975-2005). Tese Doutorado. Nitéroi: Universidade Federal Fluminense, 2019.

MATA, Inocência. A Literatura Africana e a Crítica Pós-colonial: Reconversões. Luanda: Nzila. 2007.

.Ficção e História na literatura angolana: o caso de Pepetela.

Lisboa: Colibri, 2012.

"O singular enfrentamento à ideologia colonial da colecção 'autores ultramarinos' da casa da estudantes do império”. In: Revista do NEPA/UFF, Niterói, v.10, n. 20, pp. 15-23, jan-jun, 2018.

"Pepetela: a releitura da História entre Gestos de Reconstrução". In: CHAVES, Rita; MACEDO, Tania (Orgs.). Portanto... Pepetela. São Paulo: Ateliê Editorial, 2009.

- Texto apresentado no X Congresso Internacional da ALADAA (Associação Latino- Americana de Estudos de Ásia e África) sobre Cultura, Poder e Tecnologia: África e Ásia face à Globalização - Universidade Cândido Mendes, Rio de Janeiro - 26 a 29 de outubro de 2000.

MESSIANT, Christine. "Transição para o Multipartidarismo sem transição para a Democracia". In.: VIDAI, Nuno e ANDRADE, Justino Pinto. (orgs). O Processo 
de Transição para o Multipartidarismo em angola. Luanda: Firmamento, 2006.

MENDY, Peter Karibe. (org.). Plurismo político na Guiné-Bissau. INEP, 1999.

MICAS, Lígia Helena. "Escrita e leitura como práticas de resistência em Angola: a literatura nos anos que rondam a independência". Revista Crioula, no 18 - $2^{\circ}$ semestre/2016.

Ministério da Economia do Plano e Integração Nacional. Instituto Nacional de Estatística e Censos. Recenseamento Geral da População e Habitação, Guiné-Bissau, 2009. III RGPH Educação e escolarização.

MOUNTAURY, Alexandre. "Colonialidade e assimetria nos contextos sulamericanos da língua portuguesa". In: ALEA, Rio de Janeiro, vol. 22/1, pp. 4758, jan-abr, 2020.

NAMONE, Dabana. A luta pela independência na Guiné-Bissau e os caminhos do projeto educativo do PAIGC: etnicidade como problema na construção de uma identidade nacional. Dissertação de mestrado. São Paulo: Universidade Estadual Paulista, 2014.

OTINTA, Jorge de Nascimento Nonato. Kikia Matcho. "O desalento do combatente, de Filinto de Barros". In: Revista Crioula, n. 8, 2010.

Representações do Intelectual: um estudo sobre Mayombe

e Kikia Matcho. Tese doutorado. São Paulo: Universidade de São Paulo, 2011.

Disponível em :https://teses.usp.br/teses/disponiveis/8/8156/tde-31082012094358/pt-br.php.

PAIGC. História da Guiné e ilhas de Cabo Verde. Porto: Afrontamento, 1974. PEPETELA. A geração da utopia. 3ạ. Edição, Lisboa: Editora Planeta de Agostini/Dom Quixote, 2000.

REIS, Carlos. Figuras da Ficção. Faculdade de Letras da Universidade de Coimbra. Centro de Literatura Portuguesa, Coimbra, 2006.

REIS, Elisa. "Percepções da elite sobre pobreza e desigualdade". In: Revista Brasileira de Ciências Sociais, vol.15, n.42, pp. 143-152, 2000. Disponível em: https://doi.org/10.1590/S0102-69092000000100010. Acesso: 04/03/2021. RIBEIRO, Calafate Margarida; SEMEDO, Costa Odete (org). Literatura da Guiné-Bissau: Cantando os escritos da história. Porto: Afrontamento, 2011. SAID, Edward W. Cultura e Imperialismo. Trad. Denise Bottman. São Paulo: Companhia das Letras, 1995.

"O papel público dos escritores". In: MORAES, Dênis. Combates e Utopias. Trad. Eliana Aguiar, Luís Paulo Guanabara. Rio de Janeiro: Record, 2004. 
Representações do Intelectual: as conferências do Reith de 1993. Trad. Milton Hatoum. São Paulo: Companhia das Letras, 2005.

SALGADO, Maria Teresa. "A presença do cômico nas literaturas africanas da língua portuguesa”. In: LEÃO, ÂNGELA Vaz (Org.). Contatos e Ressonâncias: literaturas africanas de língua portuguesa. Belo Horizonte: PUC Minas, 2003. SARAIVA, Sueli da Silva. O pacto das elites e a sua representação no romance em Angola e Moçambique. Tese Doutorado. São Paulo: Universidade de São Paulo, 2013.

O pacto das elites e a sua representação no romance em Angola e Moçambique. Lisboa: Associação das Universidades de Língua Portuguesa (AULP), 2016.

SILÁ, Abdulai. Dois tiros e uma gargalhada. Bissau: Ku Si Mon Editora, 2013. SILVA, Vítor; Manuel de Aguiar. Teoria da Literatura. Coimbra: Almedina, 1990. SANTOS, Boaventura de Sousa. (Org.). A globalização e as ciências sociais. São Paulo: Cortez, 2002.

. "Para além do pensamento abissal: das linhas globais a uma ecologia de saberes". In: Epistemologias do sul. São Paulo: Cortez, 2010. MENESES, Maria Paula. (Orgs.) Epistemologias do Sul. Coimbra; Almeidina, 2009.

SUCUMA, Arnaldo. 0 ensino Superior na Guiné-Bissau: elementos estruturais, conjunturais e suas implicações no desenvolvimento das universidades guineenses. Tese Doutorado. Pernambuco: Universidade Federal de Pernambuco, 2018.

TRIGO, Salvato. "Alteridade das Literaturas africanas em língua portuguesa". In:

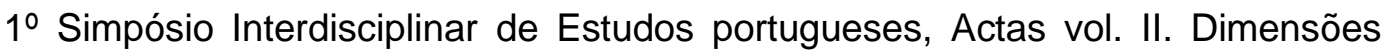
das alteridades nas culturas de língua portuguesa - o outro. Lisboa: Departamento de Estudos Portugueses, Faculdade de Ciências Sociais e Humanas, Universidade Nova de Lisboa, 1985, pp. 469 - 486.

UKUMA, Jorge Ngonga. "Do colonialismo ao fim da guerra". In. Angola: 30 anos de independência, 3 anos de paz. Publicação bilíngue (russo e português) M. “Editorial "OOO"PRAD”, 2005.

VALANDRO, Letícia. "Literatura, memória e nação na Guiné-Bissau". In: Cadernos Espuc, Belo Horizonte, n. 20, 2010.

VEIGA, Luiz Maria. De armas na mão: Personagens-Guerrilheiros em romances de Antonio Callado, Pepetela e Luandino Vieira. 2015. 401. f. Tese (Doutorado) - Departamento de Letras Clássicas e Vernáculos da Faculdade de 
Filosofia, Letras e Ciências Humanas, Universidade de São Paulo. São Paulo. 2015.

VAZ, Carlos. Os irãs de Bassarel Tcholona. In: Revista de letras, artes e cultura, Bissau, INEP, 2/3 (1), pp. 16-17, 1994.

VENÂNCIO, José Carlos. Literatura e poder na África Lusófona. Lisboa: Ministério da Educação; Instituto de Cultura e Língua Portuguesa, 1992.

. Uma perspectiva etnológica da literatura angolana. Lisboa:

Ulmeiro, 1993.

VIEIRA, José Luandino. De rios velhos e guerrilheiros: I. O livro dos rios. 2 ed. Lisboa: Editora Caminho, 2006.

YALÁ, Carlos. "Situação atual de ex-combatentes da liberdade da Pátria". [Entrevista concedida a] CUMBA, Fernando Nhaga. In: O passado no presente e a literatura Guineense do Século XXI a partir do romance Kikia Matcho: o desalento do combatente. Dissertação de mestrado. Lisboa: Universidade de Nova Lisboa, 2017. 